\title{
NÍVEIS DE PROTEÍNA E ENERGIA EM RAÇÕES E MANEJO DE CAPIVARAS (Hydrochoerus hydrochaeris hydrochaeris L. 1766) EM CRESCIMENTO
}

\section{PAULO CESAR MACHADO ANDRADE}

Engenheiro Agrônomo

\author{
Orientador: Prof. Dr. ABEL LAVORENTI
}

Dissertação apresentada à Escola Superior de Agricultura "Luiz de Queiroz", da Universidade de São Paulo, para obtenção do título de Mestre em Agronomia, Área de Concentração: Ciência Animal e Pastagens.

P I R A C I C A B A

Estado de São Paulo - Brasil

Outubro - 1996 
Dados Internacionais de Catalogaçāo na Publicaçāo (CIP) DIVISĀO DE BIBLIOTECA E DOCUMENTAÇĀO - Campus "Luiz de Queiroz"/USP

Andrade, Paulo Cesar Machado Niveis de proteina e energia em raçōes e manejo de capivaras (Hydrochoerus hydrochaeris hydrochaeris L. 1766) em crescimento / Paulo Cesar Machado Andrade. - Piracicaba, 1996. 150 p. : il.

Dissertaçăo (mestrado) - Escola Superior de Agricultura Luiz de Queiroz, 1996. Bibliografia.

1. Capivara - Alimentação 2. Capivara - Manejo 3. Digestibilidade 4. Energia em ração Nivel 5. Proteína em ração - Nivel 1. Título

CDD 636.9323 


\title{
NÍVEIS DE PROTEÍNA E ENERGIA EM RAÇÕES E MANEJO DE CAPIVARAS (Hydrochoerus hydrochaeris hydrochaeris L. 1766) EM CRESCIMENTO
}

\author{
PAULO CESAR MACHADO ANDRADE
}

Aprovada em: 02 /12/1996

Comissão julgadora:

Prof. Dr. Abel Lavorenti ESALQ/USP

Prof. Dr. Valdomiro Shigueru Miyada ESALQ/USP

Prof. Dr. Augusto Shynia Abe

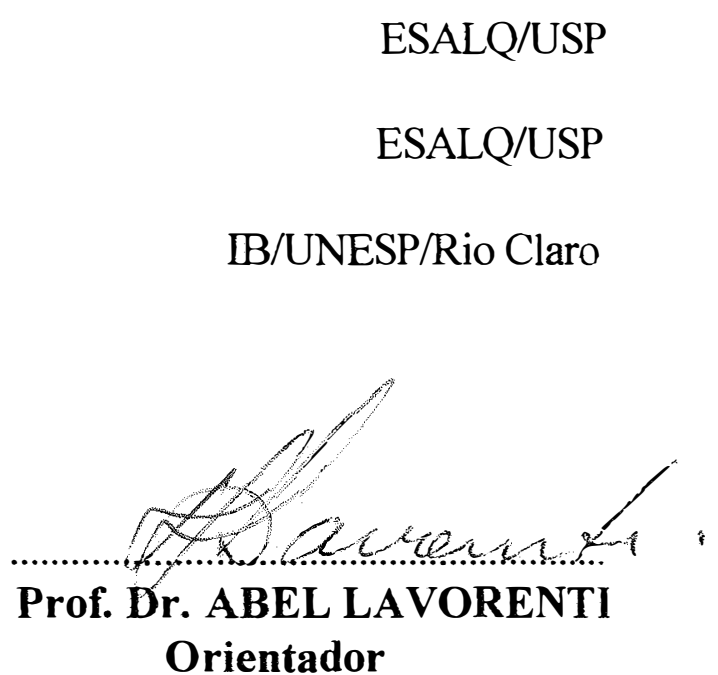


EICOBÉ CHERAMOIN GOÉ, GOÉ

PI PÉ ÇUI PARANÃ,

CI'IYA MARẼ ÇUPÉ PAPÁRI.

HANARÉ CARUE ARIPÓI ARUEIRA !

ÇUIWARA YÃ'Ã TAMA ÇUI ICAMIABAS,

$A Y U A E ́$ ARU I AWÁ PUÇU IWITÉ

RECÉ IKWÉ!

YÃ'A IWI ERETÁ ÇUI CE MIRA,

I APÉ ERETÁ CE PIÁ !

(Nheengatu* ${ }^{*}$

"Mãe Natureza, mostre a tua beleza Espelha nas águas o brilho do Sol, o clarão do luar

Mãe Natureza mostra tua grandeza Nas cores que formam o arco-íris, nas cores da vida.

Vai piracema na dança das águas Voa nas asas do vento gavião!

És o encontro de todas as raças, És o encontro das águas em meu coração ! És a força dos ventos, dos mares, dos lagos, Dos rios, furos, igarapés,

Das matas, das campinas, dos sertões, Dos vales, das montanhas, das planícies, estrelas do céu, Natureza Mãe, Natureza mãe !"

(Ronaldo Barbosa - CAPRICHOSO, 1994)

* "Guerreiros do Passado,

Nos caminhos desse rio, muita história pra contar.

O sol que toca na copa das árvores não alcança o chão !

Nesta terra das Icamiabas,

Só os bravos e os que respeitam a floresta

Sobrevivem!

Esta terra pertence ao meu povo e nela está o meu coração !" 
A ALBERTO JOSÉ MACHADO, meu avô, homem do campo, simples e determinado, que soube com seus feitos e suas histórias, ensinar-me as maiores lições de respeito à natureza e a paixão pela terra.

DEDICO

Aos povos da Amazônia, fortes e bravos que, na dura lida do dia-a-dia, aprenderam o verdadeiro manejo da floresta e seus animais, OFEREÇO.

Aos meus pais e a todos meus familiares pelo apoio, amor e compreensão em todos os momentos

MINHA ETERNA GRATIDÃO

À menina do Purupuru, do Sol e da Lua, do Frevo e do Maracatu, MEU AMOR E MINHA GRATIDÃO. 


\section{AGRADECIMENTOS}

A Deus, força e luz, presente em todos os degraus de minha vida.

Ao Prof. Dr. Abel Lavorenti, pela oportunidade, orientação e condições propiciadas.

Ao Eng ${ }^{0}$ Agrônomo Sérgio Luiz Gama Nogueira Filho, mestre em Ciência Animal e Pastagens, pesquisador do Departamento de Zootecnia, pela amizade, pelo apoio, pelos ensinamentos e pela grande colaboração e esforço para que este trabalho se realizasse.

À Escola Superior de Agricultura "Luiz de Queiroz", através do Departamento de Zootecnia, pela acolhida amiga durante o curso e pela moradia na vila estudantil da pós-graduação.

Ao Conselho Nacional de Desenvolvimento Científico e Tecnológico (CNPq) pela bolsa de estudo concedida.

Aos professores Dr. Valdomiro S. Miyada e Dr. Irineu Umberto Packer, pelos ensinamentos e sugestões no desenvolvimento desse trabalho.

Aos funcionários do Departamento de Zootecnia que auxiliaram, direta ou indiretamente, na realização deste trabalho, em especial aos amigos Sérgio V. Pena, Jorge L. F. de Andrade, Francisco M. de Oliveira, Adão L. da Silva, José Augusto Alves, Antônio Carlos Oliva, José Pires A. Sobrinho e Edson R. Davanzo.

Ao funcionário Carlos Cesar Alves, técnico do laboratório de bromatologia do Depto. de Zootecnia, pela profunda paciência e colaboração na realização das análises laboratoriais. 
Aos colegas bolsistas de aperfeiçoamento e estagiários da Comissão de Investigação de Biologia e Zootecnia de Animais Silvestres (CIZBAS), Alcester "Téti" Mendes (zootecnista), Luciana B. de Miranda (veterinária), Ana Cláudia "Meguinha" Alves, Eduardo "Downtown" B.Bastos, Karla "Etiqueta"Antiqueira, Maurício "Tereça" M.da Silva, Alessandra "Quaresmeira" de Carvalho, Regina "Bébi" Keigo, Alexandre "Barrako" Duarte e Márcia F. Nogueira (veterinária), pelas duras horas de trabalho e pelas gargalhadas nas horas de lazer.

À Dra. Karin Werther, da Faculdade de Veterinária da UNESP/Jaboticabal pelas necrópsias e análises histopatológicas e à Dra. Márcia Catroxo do Instituto Biológico de São Paulo pelas análises de virologia.

A Regina L. Engel Moraes e ao Dr. Samário R. Menezes, amigos do zoológico de Piracicaba, por toda colaboração e apoio (animais, câmara fria, etc.) e a Verinha, do posto de saúde da prefeitura, pelas radiografias.

A Cláudia C. de Camargo, Creide E. Martins e Vera L. Graciano, secretárias do Depto. de Zootecnia, pelas fotocópias, telefonemas, fax, recados, enfim, pela paciência e prestatividade em qualquer momento.

Ao amigo Fábio Prudêncio de Campos, pelo apoio, pelos ensinamentos, pelas dicas e pelos conselhos.

Aos amigos que concederam-me, por infindáveis horas, o empréstimo de seus computadores, constituindo-se na minha central de processamento, Elton Araújo, Heron Salazar Costa, Cristina M. Lacerda e Michelle N.Costa e aos demais amigos de vila estudantil pela feliz convivência e amizade.

Ao Júnior e ao Rinaldo, filhos do seu Ribamar, pela morada e pela amizade no meu primeiro mês em Pira. 
Às bibliotecárias Eliana M. Garcia Sabino e Kátia M. de Andrade Ferraz, pela revisão das referências bibliográficas.

A tia Maria, Socorrinho, Roque, Fabinho. Juliana, Eduardo e Adriana, minha família em São Paulo, por todo o apoio que me deram e, principalmente, por todo carinho e compreensão, por mais que eu sempre chegasse atrasado.

A todos aqueles que, de alguma forma, colaboraram para a realização deste trabalho. 


\section{SUMÁRIO}

Página

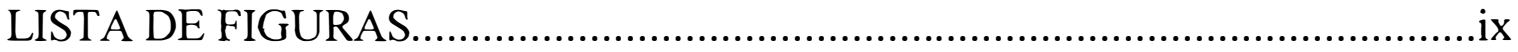

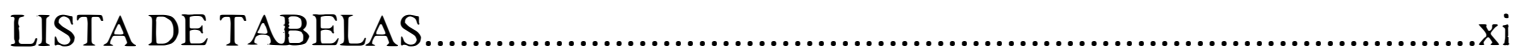

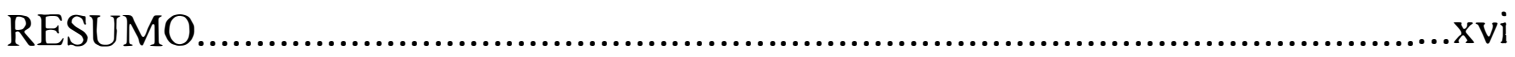

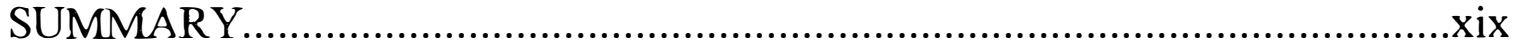

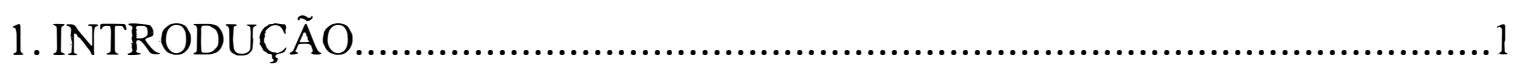

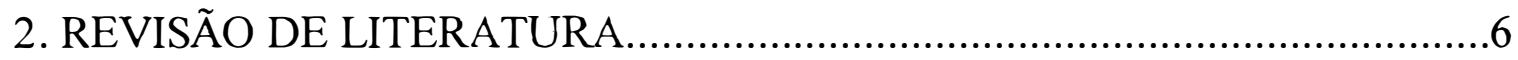

2.1. Manejo e exploração econômica de animais silvestres...................................6

2.2. A Capivara (Hydrochoerus hydrochaeris hydrochaeris Linée, 1766)..........13

2.3. Alimentação e digestão na capivara............................................................17

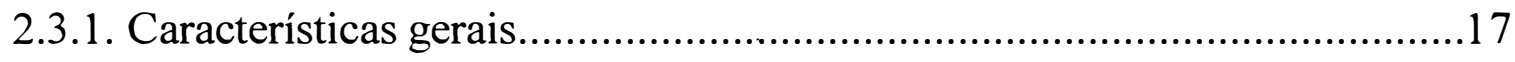

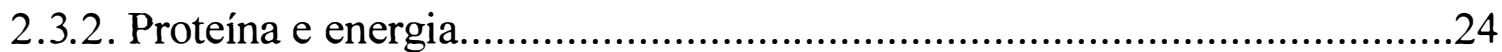

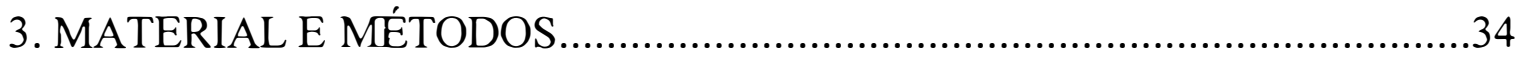

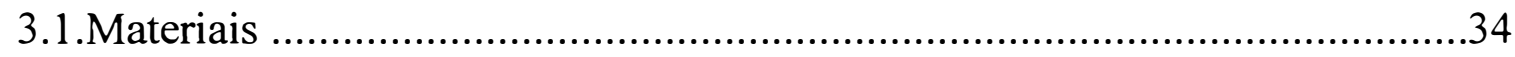

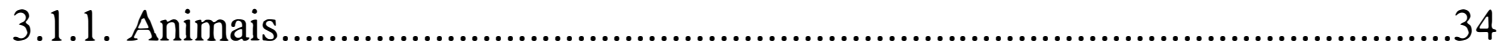

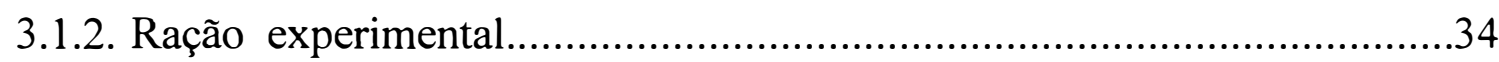

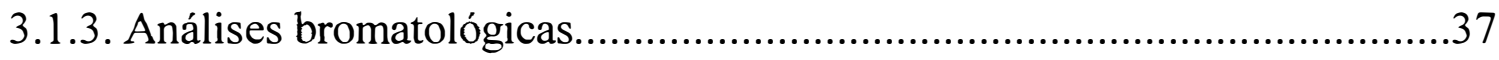

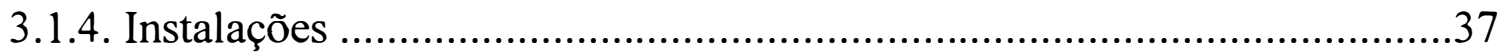

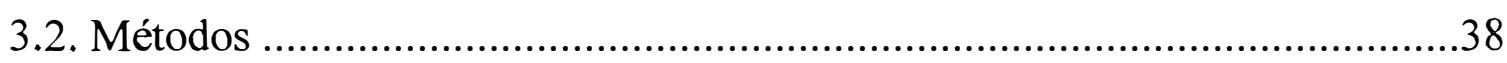

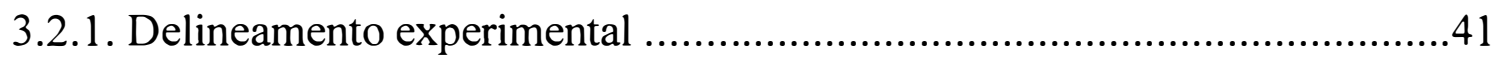

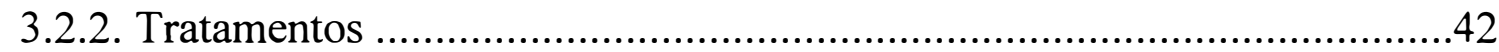

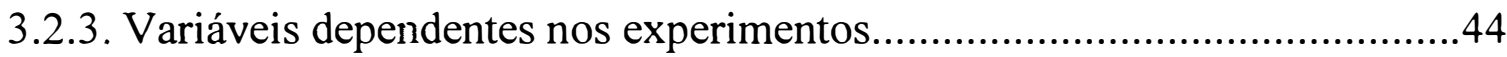

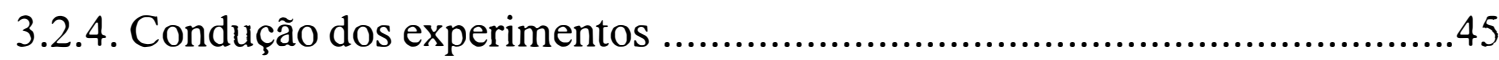


3.2.5. Análises das rações, das fezes e da urina .............................................49

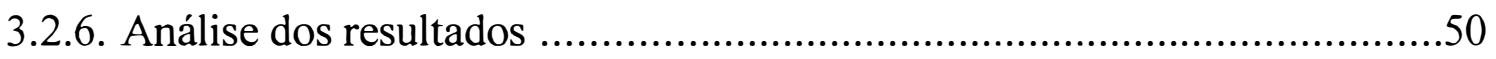

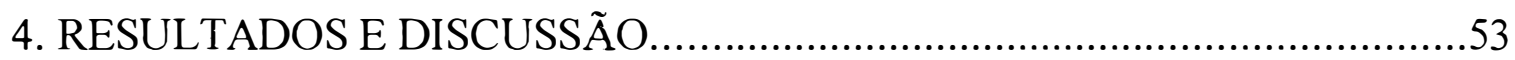

4.1. Experimento I- A : Níveis de proteína e energia bruta na ração:...................53

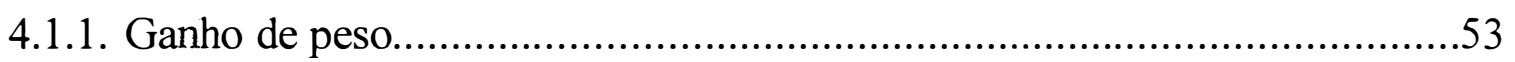

4.1.2. Consumo

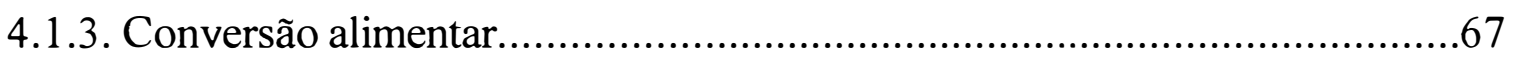

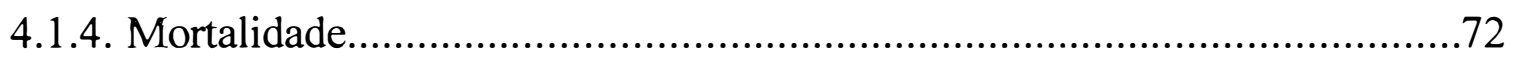

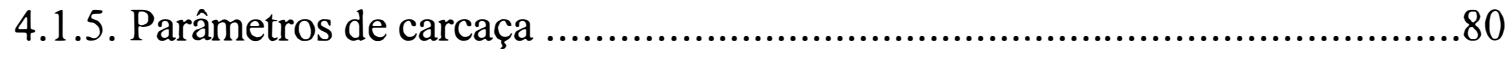

4.2. Experimento I- B:Diferentes tipos de dieta e de áreas de confinamento:......90

4.2.1. Ganho de peso, consumo em matéria seca e conversão alimentar:............90

4.2.2. Parâmetros de carcaça ..............................................................................96

4.3. Experimento I-C : Diferentes idades iniciais de arraçoamento....................99

4.4. Experimento II : Ensaio de digestibilidade das rações experimentais:.........103

4.4.1. Digestibilidade da matéria seca..............................................................104

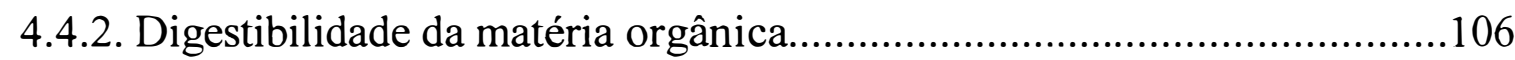

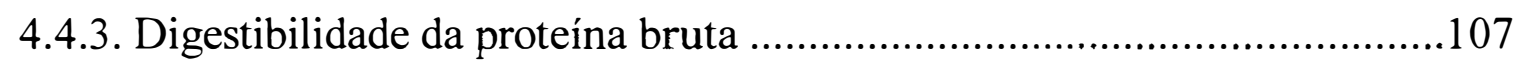

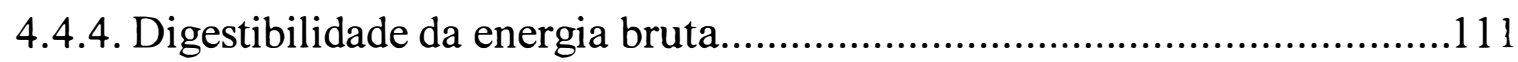

4.4.5. Digestibilidade do extrato etéreo:........................................................112

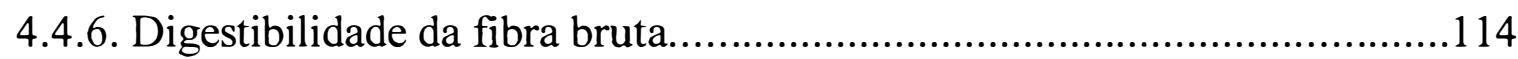

4.4.7. Digestibilidade da fibra em detergente neutro (FDN) ............................115

4.4.8. Digestibilidade da fibra em detergente ácido (FDA) ...............................116

4.4.9. Digestibilidade do extrativo não-nitrogenado .......................................117

4.4.10. Considerações gerais sobre o ensaio de digestibilidade:........................118

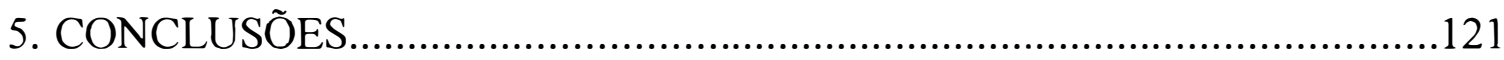

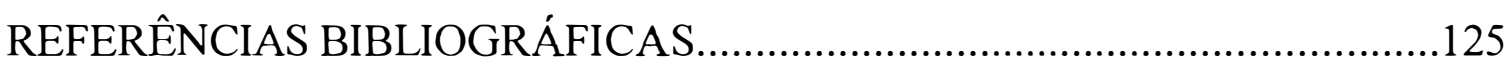

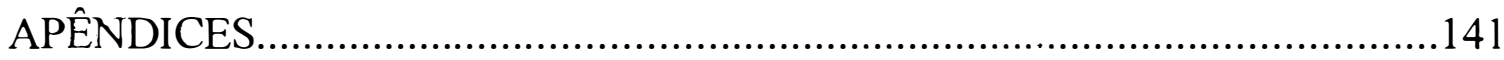




\section{LISTA DE FIGURAS}

Página

1 Número de Capivaras (Hydrochoerus hydrochaeris hydrochaeris L., 1766) exploradas no Brasil e na Venezuela entre os anos de 1958-1987

2 Baias experimentais 40

3 Gaiolas metabólicas utilizadas no ensaio de digestibilidade.

4 Meia carcaça esquerda de capivara (H. h. hydrochaeris L. 1766)

5 Cortes comerciais de capivara (H. h. hydrochaeris L., 1766)

6 Crescimento em peso de capivaras (H.h. hydrochaeris L. 1766) submetidas a rações com diferentes níveis de PB (13,5 e 20,0\%) e EB (4.000 e $4.500 \mathrm{kcal} / \mathrm{kg}$ ) e curva de crescimento das capivaras do projeto da CIZBAS/ESALQ/USP

7 Curvas de crescimento de capivaras (H. h. hydrochaeris L. , 1766) com diferentes idades iniciais de arraçoamento e confinamento 
Página

8 Regressão entre o consumo diário de nitrogênio e o balanço de nitrogênio para capivaras com $12 \mathrm{~kg}$ de PV alimentadas com ração concentrada com diferentes níveis de proteína bruta $(13,5$ e $20,0 \%)$. 


\section{LISTA DE TABELAS}

Página

1 Características do trato digestivo da capivara............................. 20

2 Comparação do volume gastrointestinal da capivara com outras espécies

3 Efeito da adição de farinha de mandioca sobre a digestibilidade em capivaras.

4 Categorias de peso, tipo de dieta, nivel protéico, consumo, GDP e conversão alimentar de capivaras (H.h.hydrochaeris)

5 Composição percentual das rações experimentais.

6 Composição químico-bromatológica das rações experimentais.

35

7 Tratamentos da parte B do Experimento I

8 Efeito de níveis de $\mathrm{PB}$ e $\mathrm{EB}$ em rações sobre o ganho médio diário de peso (GDP) de capivaras em crescimento (g) 
Página

9 Ganho médio diário de peso em relação ao peso metabólico e em percentagem do peso vivo médio de capivaras em crescimento..........

10 Efeito de níveis de $\mathrm{PB}$ e EB em rações sobre o peso vivo de capivaras em crescimento aos 246 dias de idade $(\mathrm{kg})$

11 Efeito de níveis de $\mathrm{PB}$ e $\mathrm{EB}$ em rações sobre o consumo médio diário em matéria seca para capivaras em crescimento (g/dia)...........

12 Efeito de níveis de $\mathrm{PB}$ e EB em rações sobre o consumo diário médio em \% do peso vivo (PV) de capivaras em crescimento (\%)....

13 Efeito de níveis de PB e EB em rações sobre a conversão alimentar média e sobre o GDP médio ajustado ao consumo de capivaras em crescimento

14 Efeito de níveis de PB e EB em rações de capivaras em crescimento sobre a taxa de incidência de doenças e a taxa de mortalidade dos animais.

15 Análise quantitativa de carcaça de capivaras (H. h. hydrochaeris L., 1766) alimentadas com rações com diferentes níveis de PB (\%) e EB ( $\mathrm{kcal} / \mathrm{kg})$ e abatidas aos 10 meses de idade 
16 Rendimento dos cortes comerciais de capivaras (H. h. hydrochaeris L., 1766) alimentadas com rações com diferentes níveis de proteína bruta $(\mathrm{P} 1=13,5 \%$ e $\mathrm{P} 2=20,0 \%)$ e energia bruta $(\mathrm{E} 1=4.000 \mathrm{kcal} / \mathrm{kg}$ e $\mathrm{E} 2=4.500 \mathrm{kcal} / \mathrm{kg})$

17 Análise das medidas lineares de carcaça de capivaras ( $H . h$. hvdrochaeris L., 1766) em crescimento recebendo dietas com diferentes níveis de PB (\%) e EB ( $\mathrm{kcal} / \mathrm{kg})$

18 Ganho médio diário de peso, consumo de MS e conversão alimentar de capivaras em crescimento sob diferentes dietas e áreas de confinamento.

19 Valores de probabilidade do teste $\mathrm{F}$ na comparação por contrastes ortogonais de GDP médio, consumo médio de MS e conversão alimentar de capivaras em crescimento submetidas a diferentes dietas e áreas de confinamento.

20 Análise quantitativa de carcaças de capivaras $(H . h$ hydrochaeris L., 1766) confinadas e semiconfinadas alimentadas com diferentes dietas.

21 Rendimento dos cortes comerciais de capivaras (H. h. hydrochaeris L., 1766) confinadas e semiconfinadas com diferentes dietas 
22 Ganho diário de peso, consumo diário de ração em MS (CDR) e conversão alimentar de capivaras com diferentes idades iniciais de

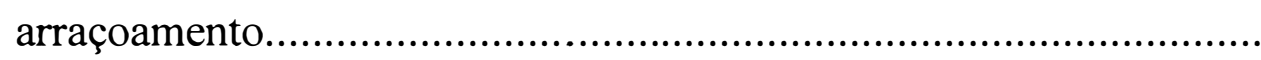

23 Efeito de níveis de PB e EB sobre os coeficientes de digestibilidade aparente da matéria seca em rações para capivaras em crescimento $(\%)$

24 Efeito de níveis de PB e EB sobre os coeficientes de digestibilidade aparente da matéria orgânica em rações para capivaras em crescimento (\%)

25 Efeito de níveis de PB e EB sobre os coeficientes de digestibilidade aparente de proteína bruta em rações para capivaras em crescimento $(\%)$

26 Efeito de níveis de PB e EB sobre os coeficientes de digestibilidade aparente da energia bruta em rações para capivaras em crescimento $(\%)$

27 Efeito de níveis de PB e EB sobre a digestibilidade aparente do extrato etéreo em rações para capivaras em crescimento $(\%)$ 
28 Quadro de análise de variância do efeito interação entre níveis de $\mathrm{PB}$ e $\mathrm{EB}$, dentro de cada fator (contraste), na digestibilidade de EE em rações para capivaras em crescimento.

29 Efeito de níveis de PB e EB sobre a digestibilidade de fibra bruta em rações para capivaras em crescimento (\%)

30 Efeito de níveis de PB e EB sobre a digestibilidade de FDN em rações para capivaras em crescimento (\%)

31 Efeito de níveis de PB e EB sobre a digestibilidade de FDA em rações para capivaras em crescimento (\%)

32 Efeito de níveis de PB e EB sobre os coeficientes de digestibilidade aparente do extrativo não-nitrogenado em rações para capivaras em crescimento (\%) 


\title{
NÍVEIS DE PROTEÍNA E ENERGIA EM RAÇÕES E MANEJO DE CAPIVARAS (Hydrochoerus hydrochaeris hydrochaeris L. 1766) EM CRESCIMENTO
}

\author{
Autor: PAULO CESAR MACHADO ANDRADE \\ Orientador: PROF. DR. ABEL LAVORENTI
}

\section{RESUMO}

Este trabalho foi conduzido, de 05/05/94 a 06/12/95, na ESALQ/USP em Piracicaba/SP, tendo como objetivos avaliar os efeitos de dois níveis de proteína bruta (13,5 e 20\%) e dois níveis de energia bruta (4.000 e 4.500 $\mathrm{kcal} / \mathrm{kg}$ ) em rações e de diferentes formas de manejo para capivaras em crescimento. Foram desenvolvidos dois experimentos: I) avaliação do desempenho dos animais nas condições de cativeiro (dividido em três partes); II) ensaio de digestibilidade das rações experimentais.

No Experimento I, parte A, foram utilizadas capivaras com peso médio inicial de $8,97 \pm 2,28 \mathrm{~kg}$ e 70 ou 150 dias de idade, distribuídas em um delineamento aleatorizado em blocos com esquema fatorial $2 \times 2$ (dois níveis de $\mathrm{PB}$ e dois níveis de EB) e cinco repetições (parcela = dois animais/baia de $40 \mathrm{~m}^{2}$ ). Os animais foram mantidos no experimento até a idade de 282 dias com peso médio de $24,94 \pm 7,72 \mathrm{~kg}$. As variáveis analisadas foram o ganho diário de peso 
(GDP), consumo diário de ração, conversão alimentar, taxa de mortalidade e parâmetros de carcaça.

Para analisar a influência do tamanho da área de confinamento e do tipo de dieta sobre capivaras em crescimento, na parte B, do Experimento I, os animais foram distribuídos em grupos com os seguintes tratamentos : G1 = confinamento em baias ( 1 cabeça/20 $\mathrm{m}^{2}$ ) e ração peletizada (utilizaram-se os dados dos animais da parte A, do Experimento I); G2 = confinamento em baias ( 1 cabeça/20 $\mathrm{m}^{2}$ ) e capim elefante (Pennisetum purpureum); G3 = semiconfinamento ( 1 cabeça/ $70 \mathrm{~m}^{2}$ ) e ração peletizada ( $17 \%$ de $\mathrm{PB}, 4200 \mathrm{kcal}$ de EB/ $\left.\mathrm{kg}\right)$; e G4 = semiconfinamento ( 1 cabeça/70 $\mathrm{m}^{2}$ ) e capim elefante mais ração farelada (18\% de PB, $3.300 \mathrm{kcal} \mathrm{de} \mathrm{EB/kg} \mathrm{).}$

A parte $\mathrm{C}$, do Experimento I, constituiu-se da análise de desempenho dos animais da parte $\mathrm{A}$ de acordo com a idade em que eles foram levados para as baias experimentais e começaram a receber ração (70 ou 150 dias).

O Experimento II teve delineamento tipo quadrado latino 4X4 (4 animais, 4 períodos de coleta), com os animais confinados em gaiolas metabólicas. As variáveis analisadas foram os coeficientes de digestibilidade das rações do Experimento I, parte A : digestibilidade da matéria seca (\%DMS) e digestibilidade dos nutrientes $(\% \mathrm{DN})$.

No Experimento I-A, não houve diferenças significativas ( $p>0,05$ ) entre os tratamentos para GDP, consumo diário, taxa de mortalidade, peso vivo do animal em jejum, peso do corpo vazio, peso da carcaça quente, perdas por resfriamento, rendimento de carcaça, peso do couro e rendimento dos cortes comerciais em relação ao peso da meia carcaça esquerda (\%MCE). 
Houve diferenças significativas $(\mathrm{p}<0,05)$ entre os animais que receberam rações com 20 e 13,5 \% de $\mathrm{PB}$, respectivamente, em conversão alimentar $(5,08: 1$ e $6,18: 1)$ e rendimento em carne $(65,65$ e $70,45 \%)$. Animais alimentados com dietas com maior nível energético e com maior nível protéico apresentaram uma tendência a ter um maior teor de gordura e maior rendimento de pernil.

No Experimento I-B não foram encontradas diferenças significativas $(p>0,05)$ para GDP entre capivaras confinadas e semiconfinadas. Animais confinados apresentaram menor consumo (312,29 vs. 563,35 g de MS), melhor conversão alimentar (5,1:1 vs. 9,58:1) e maior taxa de mortalidade $(20,41$ vs. $0 \%$ ) do que os semiconfinados, que apresentaram menor teor de gordura $(14,75$ vs. $16,88 \%)$ e maior rendimento de pernil (33,17 vs. $31,88 \%)$. Animais alimentados somente com capim tiveram o menor GDP $(18,80 \mathrm{~g})$ e a pior conversão alimentar $(22,2: 1)$ com $25 \%$ de mortalidade.

Entre os animais que foram confinados e começaram a receber ração aos 70 ou aos 150 dias de idade não houve diferenças $(p>0,05)$ em GDP e conversão alimentar. Animais de 70 dias apresentaram, em média, uma maior ingestão de MS (339,7 g) do que os de 150 (285,5 g), e uma maior taxa de mortalidade $(30,3$ vs. $0 \%)$.

Os coeficientes de digestibilidade de matéria seca, matéria orgânica, proteína bruta, energia bruta, extrato étereo, fibra bruta, fibra em detergente neutro e fibra em detergente ácido e extrativo não nitrogenado foram, em geral, reduzidos pelo maior nível de proteína (20\% de PB) e pelo maior nível de energia (4.500 kcal de EB/kg). 


\title{
EFFECTS OF DIETARY LEVELS OF PROTEIN AND ENERGY AND MANAGEMENT SYSTEMS FOR YOUNG CAPYBARAS (Hydrochoerus \\ hydrochaeris hydrochaeris L. 1766)
}

\author{
Author: PAULO CESAR MACHADO ANDRADE \\ Adviser: PROF. DR. ABEL LAVORENTI
}

\section{SUMMARY}

This study was conducted at ESALQ/USP, Piracicaba/SP, from $05 / 05 / 94$ to $06 / 12 / 95$. The objectives were to evaluate the effects of two levels of CP (13.5 and 20\%) and two levels of GE (4,000 and 4,500 kcal $/ \mathrm{kg})$ and of different management systems on the growth of young capybaras.

In the experiment $\mathrm{I}$, part $\mathrm{A}$, capybaras averaging of $8.97 \pm 2.28$ $\mathrm{kg}$ of $\mathrm{BW}$ and 70 or 150 days of age were distributed in randomized complete blocks design and 2X2 fatorial arrangements (two levels of CP and two levels of GE) with five replications. The final age was 282 days with animals averaging of $24.94 \pm 7.72 \mathrm{~kg}$ of BW.

In the experiment $\mathrm{I}$, part $\mathrm{B}$ analysed the influence of the size of the area and the kind of diet on the growth of young capybaras. The treatments were: $\mathrm{G} 1=2$ animals in pen of $40 \mathrm{~m}^{2}$ and pelletized ration; $\mathrm{G} 2=2$ animals in pen of $40 \mathrm{~m}^{2}$ and diet only with elephant grass (Pennisetum purpureum); G3=6 animals in a corral of $400 \mathrm{~m}^{2}$ fed with pelletized ration $(\mathrm{CP}=17 \%$ and $\mathrm{GE}=4,200$ $\mathrm{kcal} / \mathrm{kg}$ ); and $\mathrm{G} 4=6$ animals in a corral of $400 \mathrm{~m}^{2}$ fed with elephant grass and 
ration $(\mathrm{CP}=18 \%$ and $\mathrm{GE}=3,300 \mathrm{kcal} / \mathrm{kg})$. The part $\mathrm{C}$ of experiment I evaluated the animals of part A performance according to the different ages (70 or 150 days) which its were confined in pens and began to receive ration.

The experiment II was a latin square $4 \mathrm{X} 4$ ( 4 animals, 4 periods, 4 treatements). The animals were confined in metabolic cages. The variables analysed were the digestibility coefficients: dry matter digestibility (\%) and nutrients digestibility (\%).

In the experiment I-A, no significant differences were observed for weight gain, food consumption, mortality rate, fasting weight, empty body weight, hot dressing weight, cooling losses, dressing percentage, leather weight and comercial cuts.

Significant statistical differences $(\mathrm{p}<0,05)$ were detected between the animals feds with rations with 20 and $13,5 \%$ of $\mathrm{CP}$, respectivelly, for feed conversion (5.08:1 and 6.18:1) and percentage meat(65.65 and $70.45 \%$ ). Animals fed with diets of higher energetic level presented a tendency of having a higher fat percetage and a higher ham percentage ( $18.99 \%$ vs. $15.91 \% ; 36.0$ vs. $26.4 \%$ ), as well as the animals fed with more protein (17.88 vs. $17.02 \%$; 34.2 vs. $30.2 \%$ ).

In the experiment I-B no significant differences were observed for weight gain between capybaras in pens and in corrals. Animals in pens were presented lower food consumption (312.29 vs. $563.35 \mathrm{~g}$ of DM), better feed conversition (5.1:1 vs. 9.58:1) and higher mortality rate (20.41 vs. $0 \%$ ) than animals in corrals, the which presented lower fat percentage (14.75 vs. $16.88 \%$ ) and larger ham percentage (33.17 vs. $31.88 \%$ ). Animals fed only with roughage had lesser weight gain(18.80g) and the worse feed conversition(22.2:1) with mortality of $25 \%$. 
Capybaras that were confined and were started receiving ration with 70 or 150 days of age didn't showed significant statistical differences for weight gain and feed conversition. Animals of 70 days presented a higher dry matter ingestion $(339.7 \mathrm{~g})$ than those of 150 days $(285.5 \mathrm{~g})$, and a higher mortality rate $(30.3$ vs. $0 \%)$.

The digestibility mean coefficients of dry matter, organic matter, crude protein, gross energy, ether extract, crude fiber, neutral detergent fiber, acid detergent fiber and nitrogen-free extract were diminisheds for the higher protein level $(20 \%$ of $\mathrm{CP})$ and for the higher energy level $(4,500 \mathrm{kcal}$ of $\mathrm{GE} / \mathrm{kg})$. 


\section{INTRODUÇÃO}

No Brasil, assim como em outros países da América Latina, África e Ásia, a fauna silvestre tem representado importante fonte protéica para a alimentação humana e, além da carne, outros produtos como couro, pele, pêlos e penas, oriundos desses animais, apresentam um alto potencial de mercado. Com isso têm-se intensificado, nos últimos anos, estudos que possibilitem a criação e o aproveitamento racional de animais silvestres em todo o mundo.

A capivara (Hydrochoerus hydrochaeris hydrochaeris L. 1766) é, das espécies silvestres nacionais, a que, possivelmente, apresenta o maior potencial zootécnico para a produção de carne e couro. Esta espécie é explorada racionalmente na Venezuela e na Colômbia, onde exemplares adultos chegam a pesar 73,5 kg (González-Jiménez, 1978). Nestes países, em geral , é feita a exploração desses animais em regime extensivo (ranching), onde bandos de capivaras semi-selvagens são manejados junto com o gado bovino (Sunquist, 1986; Cheeke, 1987). Segundo González-Jiménez (1995), em estudo publicado pela FAO, a capivara já se encontra em um estado tão avançado do processo de domesticação (criação em cativeiro, tolerância ao homem e utilização comercial), que se poderia considerar que a América do Sul possui um novo animal doméstico com manejo e uso bem estabelecidos. 
No Brasil, onde existem registros de que alguns espécimes podem pesar até $92,0 \mathrm{~kg}$, a carne de capivara é consumida em todo país, especialmente na Amazônia, onde é considerada, entre 13 espécies, a sétima carne de caça mais apreciada (Piccini et al.,1971; Wetterberg et al., 1976). Nos últimos anos, tem crescido no país o número de criatórios comerciais de animais silvestres, principalmente nos estados do Mato Grosso do Sul e em São Paulo $\left(\operatorname{IBAMA}^{1}\right)$.

Apesar do atual estado de criação da capivara, ainda existem poucos estudos sobre a utilização de alimentos e as exigências nutricionais deste animal. A maioria dos trabalhos existentes foram realizados no Instituto de Produção Animal (IPA), na Universidade Central da Venezuela, em Maracay-El Limon, especialmente pelos pesquisadores Ojasti, González-Jiménez, Parra, Escobar, Barbella e Herrera que conduziram experimentos mais direcionados para o sistema de criação venezuelano, principalmente nas áreas de biologia, ecologia e etologia (Silva Neto, 1989).

O manejo extensivo de animais silvestres, na natureza, para a exploração econômica de seus excedentes não é legalizado no Brasil. O IBAMA (Instituto Brasileiro de Meio Ambiente e dos Recursos Naturais Renováveis) permite apenas criadouros comerciais em regime intensivo ou semi-intensivo. Neste contexto, a Comissão de Investigação de Zootecnia e Biologia de Animais Silvestres (CIZBAS) do Departamento de Zootecnia da Escola Superior de Agricultura “Luiz de Queiroz”(ESALQ) da Universidade de São Paulo, tem desenvolvido, desde 1985, trabalhos na área de nutrição e manejo de capivaras

\footnotetext{
${ }^{1}$ IBAMA. Exploração Racional da Fauna : Aspectos Legais e Comerciais. Palestra proferida no Curso de criação de animais silvestres em cativeiro. FCAV/UNESP- FINEP, Jaboticabal, agosto de 1994.
} 
em cativeiro (Lavorenti, 1989; Lavorenti et al., 1989; Silva Neto, 1989; Albuquerque, 1993; Bernardi, 1993).

O desempenho e a sanidade de animais silvestres criados em cativeiro estão intimamente relacionados às dietas que estes recebem (Allen \& Ullrey, 1992). A capivara (mesmo após várias gerações em cativeiro) ainda mantém padrões comportamentais da vida selvagem, estando por isso mais susceptível a situações de estresse do que outros animais domésticos manejados intensivamente. Dietas com deficiência ou excesso de nutrientes podem, portanto, não só afetar o potencial produtivo desta espécie, como diminuir a resistência desses animais às condições de estresse.

Silva Neto (1989) estudou a influência dos níveis de proteína bruta (PB) em rações para capivaras com peso médio inicial de $20 \mathrm{~kg}$ e final de $40 \mathrm{~kg}$. Entre os três níveis de PB (13,5 , 17 e 20,5 \%) fornecidos em rações isocalóricas não foram observadas diferenças significativas $(p>0,05)$, sendo observado, entretanto, uma tendência de correlação linear positiva entre níveis de PB e ganho de peso.

Mais estudos sobre as exigências nutricionais de capivaras se fazem necessários. Entretanto, podem-se pressupor algumas hipóteses para os resultados obtidos por Silva Neto (1989). A primeira delas seria de que animais com peso médio acima de $20 \mathrm{~kg}$ já haveriam chegado em uma fase de desaceleração no crescimento para espécie (por volta dos 6 a 8 meses de idade), e a maior velocidade de crescimento e, portanto, a maior necessidade em termos de proteína, estaria em uma fase anterior (Ojasti, 1973). A segunda hipótese seria o fato de as dietas serem isocalóricas, o que talvez tenha resultado em um menor aproveitamento dos níveis mais elevados de proteína. Finalmente, poder-se-ia considerar o alto grau de variabilidade genética, ainda presente nesta espécie, e a 
estratégia usada por esses animais para manter o seu balanço de nitrogênio, que ainda não está bem definida (possivelmente façam cecotrofagia como os coelhos González-Jiménez, \& Escobar, 1975 ; Herrera, 1985).

Segundo a FAO (1987), entre as prioridades de pesquisa com capivaras, está a determinação de suas exigências nutricionais energéticas e protéicas. Além disso, González-Jiménez (1995) estabeleceu como metas na criação de capivaras em cativeiro, o abate comercial aos 10 meses com um peso em torno de $35 \mathrm{~kg}$ e um rendimento de carcaça de $50 \%$, sendo a idade à desmama reduzida de 9 para 6 semanas, com os filhotes pesando de 5 a $6 \mathrm{~kg}$. Índices dessa ordem, só poderão ser alcançados com animais que recebam em sua dieta, além de alimentos volumosos, um concentrado que venha ajudar a suprir suas exigências nutricionais. 
O presente estudo teve, portanto, como objetivos :

- Avaliar os efeitos de dois níveis de proteína bruta (13,5 e $20 \%)$ e dois níveis de energia bruta $(4.000$ e $4.500 \mathrm{kcal} / \mathrm{kg})$, sobre a performance de crescimento de capivaras no período pós-desmama (com 70 e 150 dias de idade) até os 8 meses de idade;

- Estudar o efeito de dois tamanhos de área de confinamento (baias de $40 \mathrm{~m}^{2}$ e piquetes de $400 \mathrm{~m}^{2}$ ) e três tipos de dietas (capim; capim e ração farelada; e ração peletizada) no desempenho de capivaras em crescimento (de 70 até 280 dias de idade);

- Determinar a digestibilidade das rações peletizadas com dois níveis de proteína bruta $(13,5$ e $20 \%)$ e dois níveis de energia bruta $(4.000$ e $4.500 \mathrm{kcal} / \mathrm{kg}$. 


\section{REVISÃO DE LITERATURA}

\subsection{Manejo e exploração econômica de animais silvestres}

A exploração da fauna silvestre pode ser dividida em dois tipos : uso direto , para produção de carne, couro, pele e penas e em parques de caça; ou uso indireto, para observação em parques turísticos. As medidas para administrar esse recurso natural podem ser negativas ou positivas. Entre as negativas podem ser citadas aquelas que afastam as comunidades tradicionais locais do uso dessa fonte de proteína animal através de leis repressivas, que acabam por resultar em problemas com a caça furtiva e no escoamento de divisas a partir do tráfico internacional de animais silvestres, que anualmente movimenta alguns milhões de dólares. Entre as medidas positivas, estão a utilização integrada e racional da fauna através de múltiplos usos tais como : caça de subsistência e esportiva, turismo ecológico, exploração integrada de animais silvestres com o gado, aproveitamento e beneficiamento de terrenos marginais e possível domesticação (Ajayi, 1995).

O Brasil e outros países da América do Sul não têm, em geral, realizado a exploração econômica de sua fauna de forma racional, predominando a caça comercial predatória e ilegal. Entretanto, em outros países da Europa, África e nos E.U.A., a fauna silvestre é manejada ou criada de forma a propiciar 
lucros àqueles que trabalham com esses animais (Silva Neto, 1990). A potencialidade de produção de inúmeros animais silvestres vem sendo pesquisada em todo o mundo, demonstrando que eles podem se transformar em fontes renováveis de produtos de grande rentabilidade, contribuindo para o aumento da produção de alimentos e concorrendo, em custo de produção, com os animais tradicionais domésticos (Torres, 1990).

O continente africano é o que apresenta o maior número de habitantes dependente da fauna silvestre. Segundo Ajayi (1995) o consumo médio anual de proteína animal silvestre, em relação ao consumo total de proteína animal, é de cerca de 70-80 \% na população rural de Camarões, 73 \% em Ghana, 80-90\% na Libéria e de $20 \%$ na população rural da Nigéria. Silva Neto (1990) citou os seguintes valores de consumo de carne de caça na África : 13,9 g/dia/pessoa em Kinshasa; 27,0 g/dia/pessoa na Costa do Marfim; 44,9 g/dia/pessoa no Kalahari; 37,2 g/dia/pessoa na região do delta do rio Niger na Nigéria. Além da importância da carne, a fauna silvestre tem sido fonte de renda através de outros usos. De acordo com Ajayi (1995), apenas a pele e o marfim de um elefante podem valer em torno de US\$ $4.000,00$ enquanto um rinoceronte (pele e chifre) custaria uns US\$ $80.000,00$, sem levar em conta sua carne. O Quênia auferiu com o turismo, em 1971, cerca de 30 milhões de dólares e a exploração extensiva da fauna silvestre renderia no Zimbabwe, em 1988, próximo a US\$ 5,70 / ha enquanto o gado bovino só daria prejuizos se levado em consideração os custos ambientais. Sem levar em conta tais custos ambientais se conseguiria um preço de US\$ 0,14 / $\mathrm{kg}$ de carne de animal silvestre contra US\$ $0,04 / \mathrm{kg}$ de carne bovina.

McDowell et al. (1983) determinaram que no Quênia se poderia obter $1,6 \%$ a mais de lucro manejando populações silvestres ao invés de criar gado, sendo que, obteriam cerca de $88 \%$ a mais de lucro com um manejo 
integrado do gado com os animais silvestres. Ajayi (1995) considera o turismo como a atividade mais importante de uso da fauna silvestre, gerando cerca de 250 a 1.500 dólares por hectare/ano no Quênia e na Tanzânia, sendo seguido pela caça desportiva e, posteriormente, pelo uso integrado as comunidades (caça comercial e de subsistência).

A despeito da tradicional importância que a fauna silvestre tem representado como fonte de alimentação para os povos da América Latina, até recentemente, muito pouco se fez para racionalizar a sua exploração. Nesse contexto, são exceções a vicunha (Vicugna vicugna) e o guanaco (Lama guanicoe) no Peru e a capivara (Hydrochoerus hydrochaeris hydrochaeris) na Venezuela, países nos quais vem sendo feita a utilização racional de tais espécies (Thellen, 1990). Segundo Dourojeanni (1985) $85 \%$ da proteína animal consumida pela população rural da amazônia peruana é obtida através da caça e da pesca. Smith (1976) estimou em cerca de $264 \mathrm{~g} /$ dia o consumo de carne de animais silvestres por pessoa para uma área da Transamazônica, próximo a Santarém, no Pará.

A Argentina exporta cerca de 90 milhões de dólares por ano em produtos de animais silvestres (peles, couro, penas, carne e animais vivos), sendo que peles e couro representam cerca de $75 \%$ deste montante e, em média, cerca de 14.000 toneladas de carne são exportadas por ano (Mares \& Ojeda, 1984). No Brasil, em 1994, foram exportadas de Mato Grosso, aproximadamente, 10 toneladas de peles curtidas e depiladas de répteis a um valor FOB de cerca de US\$ 609.000,00 (Benchimol, 1994).

A capivara tem sido tradicionalmente explorada na Venezuela para a produção de carne salgada (principal produto) e couro. Sua caça ficou proibida no país entre os anos de 1963 e 1967, quando foram realizados estudos 
que permitiram o seu posterior manejo racional de populações naturais em regime extensivo em grandes ranchos de criação de gado (Ojasti, 1973). A carne possui excelentes características nutricionais (Fuerbringer, 1974;Lavorenti, 1989; Frasson \& Salgado, 1990) e o couro é de ótima qualidade (impermeável, leve, fibras em um só sentido e poroso), sendo utilizado para confecção de calçados, luvas e vestuário (González-Jiménez, 1977). O óleo de capivara pode ser utilizado para fins medicinais e os pêlos para fabricação de pincéis (Fuerbringer, 1974; González-Jiménez, 1977; Alfinito, 1978).

Segundo González-Jiménez \& Parra (1973), o gado bovino apresenta uma maior eficiência para produção de carne $(36,2 \mathrm{~kg}$ de carcaça/animal/ano) do que a capivara (10,2 kg/animal/ano), entretanto tem uma eficiência reprodutiva 6,25 vezes menor que a capivara $(0,04$ versus $0,25 \mathrm{~kg}$ de filhote/kg de matriz/ano). Escobar (1973) observou uma produção para as capivaras do Rancho El Frio, em Apure, na Venezuela, de cerca de 78,8 $\mathrm{kg} / \mathrm{ha} /$ ano contra $11,6 \mathrm{~kg} / \mathrm{ha} / \mathrm{ano}$ para os bovinos. Negret (1979) determinou que a capivara apresenta uma eficiência para produção de carne quatro vezes maior que a dos bovinos nas condições do Pantanal Matogrossense $(378 \mathrm{~g} / \mathrm{ha} / \mathrm{dia}$ versus $94,3 \mathrm{~g} / \mathrm{ha} / \mathrm{dia}$, para taxas de lotação de 18 cabeças/3 ha e 1 cabeça./ 3 ha, respectivamente).

Estima-se que cerca de 30 a 50 mil capivaras são abatidas legalmente por ano na Venezuela (Sunquist, 1986), o que produziria um total de 400 toneladas de carne salgada por ano, com uma receita de cerca de 0,7 milhões de dólares por ano, entre 1975-85 (Ojasti, 1991). A Colômbia produziu em média, nos anos 60, cerca de 281 toneladas de carne de capivara por ano, sendo que, exportou uma média de 25.900 couros (Ojasti, 1991); a Argentina exportou, em média, cerca de 19.882 couros por ano a um valor total de 0,21 milhões de dólares (Mares \& Ojeda, 1984); a Amazônia peruana apresentou uma média 
anual de 7.680 couros entre 1962-72 (Ojasti, 1991); no Brasil, onde a caça é proibida desde 1967, a média anual , entre 1960-69, foi de 155.000 couros (Anuário Estatístico do Brasil, 1965-70).

$\mathrm{Na}$ Venezuela, a carne salgada de capivara é vendida a cerca de US\$3,50/kg, e na Argentina, principal comprador do couro venezuelano, o couro cru atinge valores de US\$ 4,00 e o couro trabalhado até US\$20,00 (Ojasti, 1991). No Uruguai, a carne de capivara é comercializada a US\$1,00/kg contra US\$1,10 a US $\$ 3,30$ da carne bovina, US\$1,80 da carne de ave e US\$1,50 do pescado $\left(\right.$ Castro $\left.^{1}\right)$. Segundo Ayres \& Best (1979), no Brasil, a carne de capivara era comercializada, em Manaus, a preços abaixo da carne de gado (US\$ 2,00 contra US\$5,66/kg). Entretanto, na atualidade, em São Paulo a carne de capivara é vendida pelo produtor a cerca de US $\$ 8,00 / \mathrm{kg}$ (ou 3 vezes mais que a carne bovina) chegando ao consumidor a valores de até US\$ 20,00/kg (Silva Neto, 1996).

$\mathrm{Na}$ Venezuela, a exploração é feita retirando-se a cada ano, durante dois meses, cerca de 20-30\% da população, em geral animais acima de 40 kg de peso vivo (Sunquist, 1986; Ojasti, 1991; Herrera, 1992). Segundo Herrera (1992), este abate de animais não altera a estrutura de idades da população, diminuindo apenas o número de animais nas faixas etárias mais elevadas, sendo que há indícios de que as populações exploradas se encontram abaixo de seu máximo potencial de produtividade devido à baixa idade e peso dos animais, já que fêmeas de maior idade e tamanho tem maior êxito reprodutivo. Entretanto, estudando o efeito da seleção do sexo no abate de capivaras na ilha de Marajó, Pará, Moreira \& McDonald (1995) determinaram que o abate seletivo tendecioso

\footnotetext{
${ }^{1}$ CASTRO, J.L.C. El carpincho en Uruguay. Trabalho apresentado no Taller Internacional sobre Estratégias para el Manejo y Aprovechamiento Racional de Carpincho (Hydrochoerus hydrochaeris), Caiman (Caiman crocodilus) y Tortugas de Água dulce (Podocnemis expansa y P. unifilis), Piracicaba, São Paulo, dezembro de 1987.
} 
para fêmeas adultas e o aumento da taxa de extração podem reduzir a taxa de fecundidade e levar a população ao colapso.

O Brasil tem protegido a sua fauna nativa através de uma legislação que proíbe caçar, apanhar e comercializar qualquer produto de animal silvestre sem a devida autorização do IBAMA (Lei No. 5.197 de 3 de janeiro de 1967, complementada pela Lei No. 7.583 de 1988). Contudo, devido a problemas como a falta de fiscalização, à falta de pesquisas sobre manejo das populações desses animais, à falta de opção econômica e de educação para as comunidades que exploram esses recursos, os efeitos da proibição total têm sido negativos, aumentando o preço do produto e seu tráfico no mercado ilegal; o que resulta em perda de divisas para o país (que foi grande exportador de produtos de animais silvestres), já que estes continuam saindo de forma ilegal, sem recolher impostos e sem qualquer controle; e, finalmente, podendo resultar na extinção de espécies (Ayres \& Best, 1979; Silva Neto, 1990; Ajayi, 1995).

Na Figura 1 pode-se observar uma comparação entre o número de capivaras exploradas, entre 1958 e 1987, no Brasil e na Venezuela, que racionalizou o sistema de exploração das populações naturais e se tornou o maior produtor mundial. Esses dados revelam o grande potencial que o Brasil possuía e possui com relação ao manejo e a criação desta espécie (Anuário Estatistico do Brasil , 1965-70; Ojasti, 1991).

Os maiores estados produtores no país, entre 1965-69 eram Mato Grosso (média de 68.320 couros/ano), Amazonas (15.179 couros/ano) e Pará (10.898 couros/ano), segundo o Anuário Estatístico do Brasil (1965-70). Entretanto, segundo Carvalho (1967), a média de couros de capivaras produzidos pelo estado do Amazonas entre 1950 e 1965 é de cerca de 33.258 couros/ ano. Conway (1973) relatou que, entre 1968 e 1969, os EUA importaram cerca de 
275 mil peles de capivaras da Amazônia Brasileira. Estes valores, provavelmente, são bastante subestimados, visto que segundo Andrade $^{1}$, a média de couros salgados de capivara trazidos, principalmente das regiões do Baixo Amazonas (Pará) e do Juruá (Amazonas), pelos grandes comerciantes de peles até o porto de Manaus era de cerca de 10.000 couros/viagem (cada viagem durava em média dois meses), sendo os meses mais produtivos os da época de cheia, de janeiro a abril. Cada couro era vendido por cerca de US\$ 0,15 e a produção exportada, principalmente, para a França para confecção de luvas e botas.

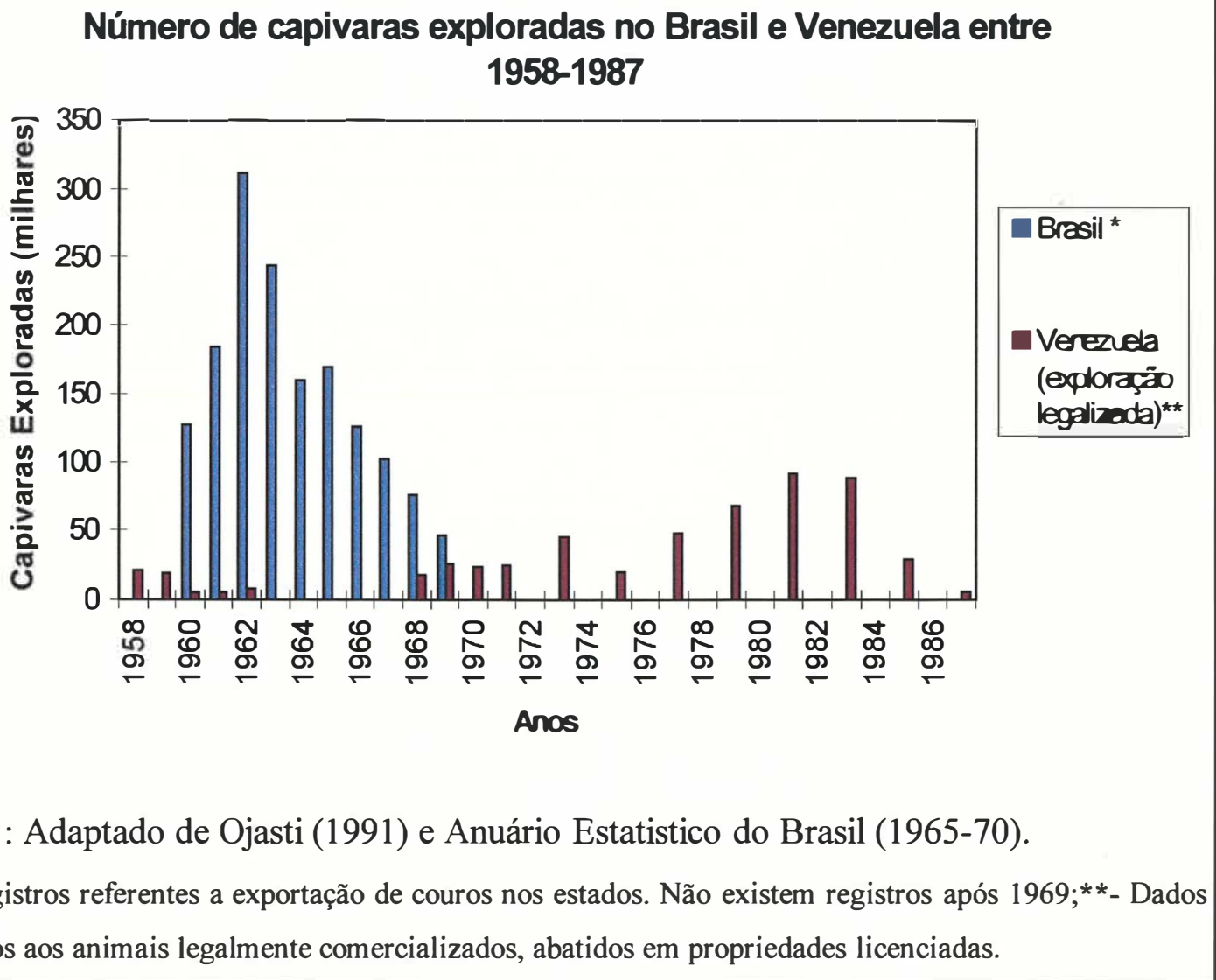

Figura 1 : Número de capivaras (Hydrochoerus hydrochaeris hydrochaeris L., 1766) exploradas no Brasil e na Venezuela entre os anos de 19581987.

\footnotetext{
${ }^{1}$ MANUEL ANDRADE, Ex-comerciante de peles e couros de Manaus/AM. Informação Pessoal.1996.
} 


\subsection{A Capivara (Hydrochoerus hydrochaeris hydrochaeris Linée, 1766)}

A capivara (Hydrochoerus hydrochaeris hydrochaeris L. 1766) é o maior roedor do mundo. Seu gênero é o único sobrevivente da família Hydrochoeridae que, segundo Mones \& Ojasti (1986), possuía três subfamílias : Cardiatheriinae (Mioceno superior e Plioceno superior), Protothydrochoerinae (Plioceno) e Hydrochoerinae (Plioceno superior até hoje) . A subfamília Hydrochoerinae inclui dois gêneros fósseis. Neochoerus e Hydrochoeropsis, além do Hydrochoerus que deu origem às subespécies existentes atualmente (Montes, 1983;González-Jiménez, 1995).

O gênero Hydrochoerus encontra-se distribuído desde o sul do Panamá até o nordeste da Argentina, em toda a área a leste dos Andes (Ojasti, 1973; Mones, 1975; Montes, 1983; Nowak, 1991). Este gênero encontra-se amplamente distribuído no Brasil, exceto em algumas regiões do semi-árido nordestino (González-Jiménez, 1995).

Segundo a FAO (1987) se convencionou denominar $H . h$. hydrochaeris a subespécie brasileira, $H$. h. isthmius a subespécie que ocorre no Panamá e Norte da Venezuela e $H$. h. uruguayensis a subespécie que ocorre no Uruguai e Argentina. A H. h. hydrochaeris mede cerca de $100-130 \mathrm{~cm}$ de comprimento incluindo cabeça e corpo, sendo que sua cauda é vestigial. Os maiores exemplares podem chegar a até $60 \mathrm{~cm}$ de altura, tendo um peso médio em torno de 50 - $60 \mathrm{~kg}$, chegando excepcionalmente aos 80 - $90 \mathrm{~kg}$ (Ojasti, 1973; Escobar \& González-Jiménez,1974; FAO, 1987; Nowak, 1991). Fuerbringer (1974) relatou a existência de um animal de pelagem mais clara que atingiria até $120 \mathrm{~kg}$, classificando-o como uma outra subespécie a Hydrochoerus hydrochaeris dabbenei, que também é reconhecida por Cabrera (1960) e Mones (1973) como 
subespécie juntamente com as outras já citadas, e que ocorre nos chacos paraguaios.

Nogueira Neto (1973) citou que segundo o Pe. Anchieta', em 1565, os índios criavam capivaras que "comem ervas, donde lhes provém o nome; são próprias para se comer; saem para pastar e voltam para casa por si mesmas". Os tupis a chamavam de caapi-guara, comedor de capim, ou caapi-goara, morador dos capinzais, de onde se originou o nome capivara (Magalhães, 1939). São animais de mastigação bastante eficiente (Ojasti, 1973), possuindo incisivos de seis a sete centímetros de comprimento que são substituídos quando o animal tem aproximadamente um ano de idade (Fuerbringer, 1974). A fórmula dentária é : i 1/1 c 0/0 pm 1/1 m 3/3, totalizando 20 peças (Mones \& Ojasti, 1986; Nowak, 1991).

O dimorfismo sexual não é evidente na capivara. Esta espécie apresenta o ânus e os órgãos genitais recobertos por uma prega cutânea. Os machos não possuem escroto, ficando os testículos aderidos ao abdômen (Ojasti, 1973; Fuerbringer, 1974).

Através do estudo de animais em vida livre, na Venezuela, Ojasti (1973) determinou que machos com peso acima dos $20 \mathrm{~kg}$ são férteis, sendo que as fêmeas, atingem a maturidade sexual por volta dos $30-40 \mathrm{~kg}$ de peso com 1,5 a 2,0 anos de idade. Trebbau (1980) observou que a cópula ocorre quase sempre na água e a idade reprodutiva é atingida aos 15 - 18 meses. Heck (1979) e Barbela (1981; 1984 e 1993) verificaram que a puberdade ocorre por volta dos 10 a 12 meses de idade, com o animal pesando entre 15 e $20 \mathrm{~kg}$, sendo ciclo estral estimado em 7,5 $\pm 1,2$ dias e a gestação em $150,6 \pm 2,8$ dias. Entretanto, outros

\footnotetext{
${ }^{\prime}$ ANCHIETA S.J.. Pe.J. de. 1554-1594- Cartas, informações, fragmentos históricos e sermões. Reedição. Rio de Janeiro: Civilização Brasileira, 1933. 567 p.
} 
pesquisadores relataram um período de gestação em torno de 115 a 125 dias (Trapido, 1949; Zara, 1973; Fuerbringer, 1974; Azcárate et al., 1979; Trebbau, 1980; Lavorenti et al., 1989; Silva Neto et al., 1990).

O pico de parição na região do Pantanal ocorre nos meses de junho a agosto, com nascimentos durante o ano todo (Alho, 1986). Na região sudeste do Brasil, segundo Lavorenti et al. (1989) e Nogueira Filho et al. (1996), a capivara tem filhotes em dois períodos bem definidos: maio e novembro a janeiro, sendo este último período o de maior pico de parição $(68,22 \%)$, o que coincide com as observações de Trebbau (1980). Em condições de cativeiro na área do projeto de criação experimental da CIZBAS/ESALQ/USP, em Piracicaba, SP, a primeira parição ocorreu em média por volta dos 790 dias (sendo que a mais nova pariu com 330 dias) com um intervalo entre partos mínimo de 150 dias (média de 283 dias), a ninhada pode variar entre 1 e 8 filhotes sendo maior a frequência de 4 filhotes (Lavorenti et al., 1989; Nogueira Filho et al., 1996), estes dados confirmam as observações de Ojasti (1973), Trebbau (1980) Barbela (1981) e Clark et al. (1992).

Nas condições de cativeiro do projeto da CIZBAS, a mortalidade dos filhotes no primeiro dia de vida é de $25,12 \%$ (Lavorenti et al., 1989) devido, principalmente, à inexperiência da mãe em limpar e proteger os filhotes de outros membros do grupo e de predadores, como urubus (Coragyps atratus). A mortalidade até a desmama é de cerca de 31,83\% (Nogueira Filho et al., 1996), e deve-se principalmente a problemas com endoparasitas (em especial Strongyloides e Eimeria). Em vida livre, Ojasti (1973) encontrou uma taxa de mortalidade de $41 \%$ para animais jovens, sendo a maior média até a idade de 7 meses (35\%). A principal causa de mortalidade registrada foi a predação por cachorros selvagens. A mortalidade dos filhotes é um fator limitante de 
crescimento da população e da produção, e é mais importante do que a própria performance reprodutiva (Ojasti, 1991).

A desmama dos filhotes em vida livre ocorre por volta dos quatro meses de idade (Ojasti, 1973). No projeto da CIZBAS o desmame é feito em torno dos 60-70 dias, sendo que é preconizado por González-Jiménez (1995), como meta a ser atingida no processo de domesticação da capivara, o desmame aos 42 dias (6 semanas) com peso médio dos filhotes entre 5 a $6 \mathrm{~kg}$. Segundo Andrade et al. (1996), utilizando-se a curva média de crescimento para espécie nas condições de cativeiro da CIZBAS, $\quad Y_{t}=52,98\left(1-0,632 e^{-0.0039 .}\right)^{3}$, os animais do projeto atingem aos 42 dias cerca de $5,3 \mathrm{~kg}$, recebendo além do aleitamento, capim elefante (Pennisetum purpureum) e uma ração à base de rolão de milho e farelo de soja fornecidos ad libitum.

A capivara é um animal de hábitos semiaquáticos que vive em grupos. Segundo Alho (1982) os habitats do Pantanal são as regiões brasileiras com maior abundância da capivara. Essa região contém os três tipos de subdivisões de habitat, descritos por Azcárate (1976), que o espaço domiciliar da capivara deve conter: (1) uma área de repouso; (2) uma área de banho e (3) uma área de pastejo, que é geralmente a área maior do território do grupo. Os espaços domiciliares normalmente pertencem a grupos sociais determinados $\mathrm{e}$ eventualmente se sobrepõem. Por força de condições locais, o aumento de sobreposição entre as áreas dos grupos normamente implica em aumento de interações agonísticas (Alho, 1986; Michi, 1993).

Em populações naturais na Venezuela, a densidade varia entre 0,5 a 3,6 indivíduos/ha e no Pantanal é cerca de 0,01 a 0,69 indivíduos/ha, variando de acordo com as estações e a disponibilidade de recursos (Ojasti, 1973; Ojasti \& Sosa Burgos, 1985; Alho et al., 1987). Em experimento, em que foram 
testadas diferentes densidades para o manejo semi-intensivo em áreas de pastagens naturais na Venezuela, Ojasti \& Sosa Burgos (1985) observaram que o aumento da densidade de 1,6 indivíduos/ha para 12 indivíduos/ha afetava consideravelmente o ganho de peso, a taxa de natalidade, a sobrevivência dos filhotes e a mortalidade dos adultos, sendo que esses efeitos foram considerados diretamente relacionados aos níveis de biomassa vegetal disponível (pastos de 5 ha são inteiramente degradados em cerca de 5 meses com a densidade de 12 ind./ha). Quando o alimento não foi o fator limitante, encontrou-se um aumento significativo no número de interações agonísticas quando foi aumentado o tamanho do grupo de 5 para 10 indivíduos em piquetes de 32 e $130 \mathrm{~m}^{2}$.

Esses animais tem uma periodicidade diária bem definida em suas atividades, pastando nas horas mais frescas do dia, sendo seu pico de atividade crepuscular, permanecendo em descanso durante o dia, à sombra ou na água, nas horas mais quentes (Ojasti, 1973; Azcárate, 1976; Jorgenson, 1986; Michi, 1993).Em ambientes onde existe pressão de atividades humanas, a capivara apresenta um padrão comportamental mais noturno (Ojasti, 1973; Trebbau, 1980; González-Jiménez, 1995).

\subsection{Alimentação e digestão na capivara}

\subsubsection{Características gerais}

A capivara é um roedor herbívoro monogástrico, isto é, que possui estômago simples, realizando fermentação do material fibroso na região do ceco que é extremamente desenvolvido (Ojasti, 1973; González-Jiménez, 1978; Baldizan et al., 1983; Cheeke, 1987). 
Em vida livre, a capivara se alimenta de plantas aquáticas e gramíneas ribeirinhas e, ocasionalmente, rói a casca de árvores (Ojasti, 1973). Ojasti (1973) faz referência à relatos de Humboldt ${ }^{1}$ e Buffon ${ }^{2}$, segundo os quais a capivara também consumiria peixe em algumas circunstâncias especiais, o que foi observado também por Zara (1973), Fuerbringer (1974) e Trebbau (1980) com animais cativos. Em cativeiro, a capivara pode ser alimentada com milho, raizes secas de mandioca, batata-doce, frutas, capins e ervas diversas conforme relata Santos (1984). No projeto da CIZBAS (Lavorenti et al., 1989; Silva Neto, 1989; Albuquerque, 1993), os animais vêm sendo alimentados com capim elefante (Pennisetum purpureum) e ração à base de rolão de milho e farelo de soja com uma média de $16 \% \mathrm{~PB}$ e $3.200 \mathrm{kcal}$ de energia bruta $\mathrm{kg}$. Os animais têm aceitado também a Brachiaria humidicola, recusando a Brachiaria decumbens. GonzálezJiménez (1978) menciona que as seguintes espécies de capim têm tido boa aceitação pelos animais em cativeiro : Brachiaria mutica, Hyparrhenia rufa, Melinis minutiflora, Panicum maximum, Paspalum plicatum, Trypsacum laxum, Axonopus scoparius e Pennisetum purpureum.

Ojasti (1973), estudando a alimentação das capivaras, observou que este animal possui uma dentição especializada para o consumo de vegetação herbácea. A disposição e a conformação dos dentes permite que esses animais cortem até gramíneas pequenas rente ao solo. Este mesmo autor verificou que após a apreensão da forragem feita pelos incisivos, este material era triturado pelos molares até partículas muito pequenas - mais de $70 \%$ do material encontrado no estômago teria tamanho entre 0,001 e $0,01 \mathrm{~mm}^{2}$ sendo que apenas

\footnotetext{
'HUMBOLDT,A. Voyages aux régions équinoxiales du Nouveau Continent fait en $1799,1800,1801,1802,1803$ et 1804 por Al. de Humboldt et A.Bonpland. Tomo VI.Chez N.Maze, Paris. 1820.318 p.

${ }^{2}$ BUFFON, G.L.L.de. Oeuvres complétes, avec des extraits de Daubenton. Bur. Public. Illustrees, Paris. 1854. Vol.IV. $784 \mathrm{p}$.
} 
$1,9 \%$ ultrapassavam os $0,1 \mathrm{~mm}^{2}$ - o que contribuiria para a excelente habilidade digestiva da capivara no consumo de pastagens. Parra et al. (1980) observaram que $80,9 \%$ das partículas encontradas no estômago de capivaras, alimentadas apenas com pasto passavam em peneiras de malha de $0,5 \mathrm{~mm}$. Movimentos de mastigação para frente e para trás, devido a uma articulação especial, também ajudam a melhorar a eficiência da mastigação (González-Jiménez, 1978).

Mones (1975) estudou a dentição da capivara quanto a suas características morfológicas. Medina (1980) realizou um estudo histológico do trato digestivo do animal. Ao microscópio óptico ele constatou as seguintes estruturas particularizadas para a capivara : a língua é rica em glândulas serosas de Von Ebner, que são as responsáveis para diluir as substâncias que chegam às papilas gustativas, o que poderia ser uma das razões para explicar a capacidade seletiva das capivaras; o esôfago possui epitélio queratinizado sem glândulas no córion e submucosa, o que protege a mucosa da passagem de alimentos grosseiros como as forragens; o estômago apresenta glândulas fúndicas muito ricas em células parietais, indicando grande produção de ácido clorídrico; o duodeno não possui glândulas de Brünner e suas válvulas coniventes são mais desenvolvidas em tamanho e número (o que indica alto poder de absorção como nos ruminantes); o jejuno possui vilosidades curtas mas em grande número; o resto das estruturas é similar ao dos demais mamíferos.

Parra \& González-Jiménez (1971) estudaram as características do trato digestivo da capivara através da análise da digesta e de seç̧ões do trato gastro-intestinal de oito animais adultos (4 machos e 4 fêmeas) sacrificados. Os resultados são apresentados na Tabela 1. 
Tabela 1 : Características do trato digestivo da capivara.

\begin{tabular}{|c|c|c|c|c|c|c|}
\hline \multirow[t]{2}{*}{ Órgão } & \multicolumn{2}{|c|}{ Peso dos órgãos } & \multirow{2}{*}{$\begin{array}{l}\text { Conteúdo de MS nos } \\
\text { compartimen- } \\
\text { tos do trato }(\mathrm{g})\end{array}$} & \multirow{2}{*}{$\begin{array}{c}\text { \% de MS nos } \\
\text { compartimen- } \\
\text { tos do trato }\end{array}$} & \multirow{2}{*}{$\begin{array}{l}\% \text { do } \\
\text { total } \\
\text { em } \\
\text { MS }\end{array}$} & \multirow[t]{2}{*}{$\mathrm{pH}$} \\
\hline & $\begin{array}{l}\% \text { do } \\
\text { PV }\end{array}$ & $\begin{array}{c}\text { \% do Peso Total } \\
\text { do Trato }\end{array}$ & & & & \\
\hline Estômago & 0,55 & 10,4 & $113 \pm 58$ & 14,75 & 9,61 & 3,5 \\
\hline Int.Delg. & 1,61 & 30,7 & $38 \pm 16$ & 10,37 & 3,23 & 6,86 \\
\hline Ceco & 1,97 & 37,7 & $869 \pm 274$ & 18,07 & 73,96 & 6,03 \\
\hline Colo & 0,68 & 12,9 & $78 \pm 31$ & 19,93 & 6,64 & 6,32 \\
\hline Reto & 0.43 & 8,3 & $76 \pm 59$ & 30,27 & 6,45 & 6,73 \\
\hline Total & 5,24 & 100 & $1175 \pm 315$ & & & \\
\hline
\end{tabular}

Fonte : Parra \& González-Jiménez (1971)

Deste estudo os autores concluíram que o ceco corresponde ao componente mais importante do sistema digestivo da capivara pois, devido à sua capacidade e $\mathrm{pH}$, nele deve se desenvolver um ativo processo de fermentação, no qual são usados carboidratos estruturais, celulose e hemicelulose que compõem a maior parte da dieta desses animais. Ao mesmo tempo, deve desempenhar um papel muito importante na economia do nitrogênio e na síntese de aminoácidos essenciais e vitaminas hidrossolúveis.

Quando se compara a capacidade relativa dos diferentes compartimentos do trato digestivo da capivara com os de outros animais, se conclui, definitivamente que ela é um herbívoro de fermentação cecal e é o monogástrico que apresenta a maior capacidade relativa para esse órgão (Parra \& González-Jiménez, 1971). Vide a Tabela 2 : 
Tabela 2: Comparação do volume gastrointestinal da capivara com outras espécies .

\begin{tabular}{|c|c|c|c|c|c|c|c|}
\hline Sistema & Bovino & Ovino & Veado & Equino & Suino & Coelho & Capivara \\
\hline \multicolumn{8}{|l|}{ Gástrico } \\
\hline Rúmen & 53 & 53 & 58 & & & & \\
\hline Retículo & 2 & 5 & 1 & & & & \\
\hline Omaso & 5 & 2 & 0,5 & & & & \\
\hline Abomaso & 6 & 7 & 1,5 & 9 & 30 & 34 & 10 \\
\hline Total & 66 & 68 & 61 & 9 & 30 & 34 & 10 \\
\hline \multicolumn{8}{|l|}{ Gástrico } \\
\hline Int.Delg. & 20 & 20 & 26 & 30 & 33 & 11 & 3 \\
\hline Ceco & 2 & 2 & 2 & 16 & 4 & 49 & 74 \\
\hline Cólon + & 11 & 10 & 11 & 45 & 33 & 6 & 13 \\
\hline Reto & & & & & & & \\
\hline
\end{tabular}

Fonte : Parra \& González-Jiménez (1971).

González-Jiménez \& Parra (1972) estudaram o conteúdo do trato gastrointestinal de capivaras abatidas no período da manhã ou no período da tarde. A análise das frações matéria orgânica $(\mathrm{MO})$, cinzas $(\mathrm{Cz})$, matéria seca $(\mathrm{MS})$, proteína bruta $(\mathrm{PB})$, fibra bruta $(\mathrm{FB})$, extrato etéreo $(\mathrm{EE})$, fibra detergente ácido (FDA), celulose, lignina e sílica revelou que : o conteúdo de MO é menor pela manhã, o que pode ser a evidência de um certo grau de coprofagia noturna, pois a ingestão das fezes levaria a um conteúdo estomacal muito rico em elementos inorgânicos, observação essa corroborada pelo maior teor de sílica, pela manhã, nesse compartimento; a MO vai diminuindo até o cólon tendo um pequeno aumento no reto, o que, somado a um maior teor de MS, parece indicar uma forte reabsorção de água e eletrólitos nesse ponto, revelando um pronunciado mecanismo de economia hídrica. 
A capacidade digestiva da capivara parece ser similar a dos ruminantes de tamanho semelhante (ovino), inclusive na capacidade de digerir fibra, sendo o ceco o local principal de aproveitamento dos carboidratos estruturais via fermentação microbiana. $O$ desdobramento da celulose e hemicelulose é feito por diversas espécies de ciliados entre elas Cycloposthim caudatum, C. compresun, $C$. cristatum, C. elongatum, $C$. hydrochoerus, $C$. incurvum, C. magnum, C. minutum, C. toxodinium, Enterophrya elongata, Hidrochoerella intestinalis, Muniziella cunhai, Paraisotricha accuminata, P. hydrochoeri, Protohalia uncita, descritas por Tengler de MaClure (1968).

Ruminantes seriam menos eficientes do que a capivara, na utilização de pastagens nativas, apesar do processo de ruminação , pois a capivara seleciona melhor as gramíneas que consome (Milan, 1978) e consegue consumir espécies que os bovinos não alcançam. Em experimento realizado incubando-se diferentes amostras de pasto em pepsina com meio ácido e, depois, em líquido cecal ou ruminal, houve, respectivamente, um incremento da digestibilidade da MS de 17 e $11 \%$, em relação as amostras que não passaram pela digestão ácida (González-Jiménez, 1977). As digestibilidades in vitro das amostras incubadas apenas no suco ruminal de ovinos e no suco cecal de capivaras foram, respectivamente, 40,24 vs. $45,52 \%$.

Segundo Ojasti (1973), a capivara consome cerca de 0,153 kg de forragem fresca e $0,040 \mathrm{~kg}$ de concentrado por quilo de peso vivo, o que dá uma média de aproximadamente $8,0 \mathrm{~kg}$ de capim fresco por dia para um animal de 50 $\mathrm{kg}$, o que coincide com a média de consumo do projeto da CIZBAS, descrito por Silva Neto (1989) e Lavorenti et al.(1990). Trebbau (1980) mencionou que uma capivara adulta ingere cerca de 4,0 kg de capim em MS/dia chegando a digerir mais de $50 \%$ da matéria orgânica (inclusive a celulose). 
Em experimentos para determinar a taxa de passagem em capivaras, Ojasti (1973) encontrou que, em 24 horas , 68\% da dieta ingerida passa pelo intestino, e o total passa em 72 horas. González-Jiménez et al. (1976) observaram que $5 \%$ do marcador usado na dieta fornecida aos animais era recuperado nas fezes após $12 \mathrm{~h}$ e $85 \%$ após $60 \mathrm{~h}$.

Ojasti (1973) realizou um ensaio de digestibilidade com Paspalum fasciculatum obtendo 54,5\% de digestibilidade para fibra bruta, 64,5 \% para proteína bruta e 53,5 \% para matéria orgânica. Parra \& González-Jiménez (1971) encontraram uma digestibilidade de matéria orgânica de 61,7\%, de matéria seca de $60,75 \%$ e de fibra bruta de 60,25\% para uma dieta de Brachiaria mutica. Bernardi (1993) estudou o efeito de níveis crescentes de volumoso sobre a digestibilidade de nutrientes em rações para capivaras. Esta autora encontrou uma digestibilidade de fibra bruta variando de 78,58 a $62,11 \%$, sendo a digestibilidade de matéria orgânica de 79,84 a $62,41 \%$ para rações contendo entre 15 e $43 \%$ de feno de Cynodon dactylon, respectivamente, sendo que níveis até $22 \%$ de alimento volumoso (níveis de 15, 22, 29, 36 e $43 \%$ de volumoso) não afetaram a digestibilidade dos nutrientes.

Baldizan et al. (1982) estudaram o efeito da adição de farinha de mandioca à dieta de feno de Cenchrus ciliaris, sobre a digestibilidade de matéria seca e da fibra bruta para capivaras e ovelhas . Os resultados são mostrados na Tabela 3. 
Tabela 3 : Efeito da adição de farinha de mandioca sobre a digestibilidade em capivaras.

\begin{tabular}{lccc}
\hline & \multicolumn{3}{c}{ Ração } \\
\hline Conteúdo de Farinha de Mandioca & 0 & 15 & 30 \\
\hline Proteína Bruta & 11,6 & 8,9 & 8,4 \\
Coeficiente de Dig. aparente da MS & 44,6 & 49,8 & 56,6 \\
Coeficiente de Dig. aparente da FB & 50,7 & 52,9 & 52,0 \\
\hline
\end{tabular}

FONTE : Baldizan et al., 1982.

O ganho de peso médio de uma capivara em vida livre no seu primeiro ano de vida está entre 53,6 a 62-67 g/dia (Ojasti, 1973 e 1978). Lavorenti (1989) relata uma média de 109,82 g/dia, para animais dos 20 aos 40 $\mathrm{kg}$ de PV, em cativeiro com uma dieta a base de $80 \%$ de volumoso (capim elefante, Penisetum purpureum) e $20 \%$ de milho fornecidos ad libitum, para um consumo de 4,1\% do PV e uma conversão alimentar de 8,65:1, sendo possível obter animais com 35 a $40 \mathrm{~kg}$ de PV em 10 a 12 meses.

\subsubsection{Proteína e energia}

A proteína e a energia são dois nutrientes importantes da alimentação animal. O consumo de alimento pelo animal é determinado, primeiramente, pelas suas necessidade energéticas (energia para a manutenção e produção). Entretanto, para um perfeito funcionamento do organismo e para o crescimento, o animal necessita que, também, suas necessidades protéicas sejam atendidas (Maynard \& Loosli, 1966; Andriguetto et al., 1990). 
Os roedores têm sido, tradicionalmente, vistos como herbívoros. Contudo, existe entre eles uma ampla variedade de adaptações desenvolvidas quanto a alimentação que incluem espécies carnívoras, frugívoras, etc. . Portanto os roedores são considerados onívoros com tendência maior para o consumo de matéria vegetal. Em média, a base das dietas fornecidas a roedores em zoológicos consiste dos seguintes valores nutricionais : $25 \%$ de proteína bruta (PB), 7,5\% de extrato etéreo (EE), $2,25 \%$ de fibra bruta $(\mathrm{FB}), 0,8 \%$ de cálcio e $0,7 \%$ de fósforo. O leite de roedores é composto em média por $71,53 \%$ de umidade, $28,66 \%$ de matéria orgânica, $48,58 \%$ de $\mathrm{EE}, 35,82 \%$ de $\mathrm{PB}, 10,11 \%$ de carboidratos, 5,45\% de cinzas, com cerca de $7.000 \mathrm{kcal}$ de EB/kg (Clark et al., 1990).

Uma questão importante no processo digestivo da capivara é de como ela aproveita a proteína microbiana oriunda do ceco após a fermentação e de como mantém equilibrado seu balanço de nitrogênio. A proteína ingerida pela capivara como parte de sua alimentação é digerida e absorvida principalmente no duodeno, sendo a digestão iniciada no estômago (González-Jiménez, 1995). Entretanto, para explicar o metabolismo do nitrogênio na capivara a partir da proteína microbiana cecal existem duas hipóteses propostas por Parra (1978): a autólise da microflora a nível de intestino grosso e a cecotrofagia.

González-Jiménez \& Escobar (1975) conduziram um experimento a fim de comparar a eficiência alimentar de herbívoros não ruminantes - a capivara e o coelho (que faz cecotrofagia) - com ruminantes (ovinos) utilizando diferentes proporções de concentrado e de forragem. Estes autores constataram que as capivaras são mais eficientes na digestão da matéria seca de concentrados, sendo menos eficientes que os coelhos e semelhantes aos ovinos na digestibilidade de volumosos. Para a digestibilidade aparente da proteína da forragem a capivara mostrou ser menos eficiente quando comparada a 
coelhos e ovinos $(16,51,37,60$ e $37,74 \%$, respectivamente). sendo tão eficiente quanto o coelho na utilização da proteína advinda do concentrado (capivara $=$ $76,01 \%$, coelho $=78,80 \%$ e ovino $=70,40 \%$, o que pode ser um indicativo da possibilidade do uso de altas proporções de concentrado na sua dieta, com alta eficiência de utilização.

Neste mesmo experimento, entretanto, foi observado que as perdas endógenas de nitrogênio eram muito maiores nas capivaras do que em coelhos e ovinos (8,45, 4,31 e 2,23\% de PB endógena fecal, respectivamente), sendo que a capivara é capaz de manter um equilíbrio do balanço de $\mathrm{N}$ quase tão eficiente quanto o ovino (2,5 vs. 2,3 g de N/ kg de peso metabólico/dia). O coelho diminui as perdas da proteína microbiana sintetizada no ceco através da ingestão de fezes especiais denominadas cecotrofos, ricas em proteína e vitaminas do complexo B (Thacker \& Brandt, 1955). O hábito de ingerir fezes para aumentar a eficiência digestiva e a taxa de crescimento, contudo, não é exclusividade da ordem Lagomorpha. A coprofagia tem sido observada como uma importante característica comportamental e nutricional de roedores, sendo que esta prática provavelmente sirva a duas funções : manter normais os níveis da flora do trato digestivo através da reinoculação e utilizar nutrientes (proteínas, vitaminas do complexo B e vitamina $\mathrm{K}$ ) sintetizados no ceco e que seriam perdidos nas fezes (Clark et al. , 1990).

De acordo com González-Jiménez \& Escobar (1975), as perdas de $\mathrm{N}$ endógeno são tão elevadas que é possível supor que a capivara não realize a coprofagia, sugerindo que deveria haver um mecanismo de autólise dos microorganismos do ceco ainda no intestino grosso. Para confirmar a hipótese de que a capivara não faria coprofagia , González-Jiménez et al. (1976) realizaram um experimento utilizando uma alta dose de óxido de cromo como marcador na alimentação de capivaras, coelhos e carneiros. Ao comparar as curvas de excreção 
eles verificaram que a curva da capivara era similar a do cameiro, e bem diferente da curva de excreção em patamares do coelho, que caracteriza a reingestão do óxido de cromo através do consumo das fezes. Logo, a capivara utilizaria uma estratégia conjunta para manter seu equilíbrio protéico, além de microorganismos que fermentam mais rápido (extraem mais energia por unidade de tempo) e seleção das forragens que consome, efetuaria a quebra e absorção da proteína microbiana através de uma estrutura adensada e bem vascularizada (apêndice) na entrada do cólon (González-Jiménez, 1977; González-Jiménez, 1995). Segundo Parra (1978), a capivara como herbívoro de porte médio, alta taxa de ingestão de forragem e proteína, eficiente sistema de mastigação e baixos requerimentos energéticos não necessitaria praticar coprofagia.

Segundo Davidson et al. ${ }^{1}$ citados por González-Jiménez (1995), existiria ainda mais um mecanismo para que a capivara não necessitasse praticar a cecotrofagia. Ela poderia dispor de um mecanismo de refluxo cólico-cecal, o qual se realizaria mediante o refluxo dos conteúdos cecais até o cólon em sua parte proximal, misturando os conteúdos quase completamente mediante movimentos peristálticos, efetuando uma separação que permite a certos componentes circular para frente (líquidos) ou para trás no ceco (sólidos) quando o resto dos componentes circula caudalmente. Esse mecanismo permitiria uma fermentação mais completa e uma melhor digestão do conteúdo da digesta.

Todavia, Ojasti (1973) cita uma comunicação pessoal do próprio González-Jiménez, segundo a qual a capivara, às vezes, excretaria fezes moles e não estruturadas que ele relacionou aos cecotrofos de coelhos. Foi Herrera (1985) o primeiro a descrever o comportamento de coprofagia da capivara na natureza,

\footnotetext{
'DAVIDSON,I.;LAYCOCK, L. \& WOODS, T. Capybara Nutritional Ecology. Depto. Animal Sci. University of Guelp, Canadá. 1984. 49 p. (Apostila - Mimeografado).
} 
não constatando diferenças deste hábito entre machos e fêmeas e entre adultos e jovens. Este autor observou que a capivara executava a ingestão de fezes de forma semelhante ao coelho, apanhando o material fecal diretamente do ânus, na maioria das vezes, e que este comportamento era mais frequente logo pela manhã bem cedo, sendo a frequência de ingestão de fezes muito maior durante a estação seca quando a alimentação é escassa e pobre em nutrientes. Herrera (1985) atribuiu o fato de González-Jiménez \& Escobar (1975) não terem observado a coprofagia por terem trabalhado com animais em gaiolas metabólicas, o que pode ter inibido esse comportamento.

No projeto da CIZBAS, ESALQ/USP, o comportamento de coprofagia já foi observado várias vezes com os animais em cativeiro. Mendes et al. (1996) realizaram um experimento no qual submeteram animais adultos a diferentes dietas: ração concentrada, ração concentrada e forragem (Pennisetum purpureum) e somente forragem. Durante o período de fornecimento dessas três dietas, estes autores coletaram fezes comuns de forma ovalada e fezes disformes e de consistência pastosa, e analisaram suas composições bromatológicas, constatando haver uma diferença média de $37,35 \%$ de proteína a mais nas fezes disformes, sendo encontrados mais constituintes da parede celular nas fezes comuns. As diferenças encontradas são comparáveis as das encontradas entre as fezes comuns de coelho e seus cecotrofos. As diferenças variaram de acordo com a dieta fornecida, havendo uma frequência maior de fezes disformes e do comportamento de ingestão de fezes (que foi observado e semelhante ao padrão descrito por Herrera, 1985) quanto mais pobre em nutrientes era a dieta. A associação dos dados comportamentais e da análise bromatológica deste estudo indicaram que a capivara realiza a cecotrofagia. Muito provavelmente, contudo, todos os mecanismos descritos contribuam no equilíbrio do balanço de nitrogênio e no metabolismo protéico da capivara. 
A capivara obtém energia para seus processos metabólicos e desenvolvimento a partir dos lipídios presentes nos alimentos mas, principalmente através da digestão e absorção de carboidratos solúveis e dos produtos da fermentação dos carboidratos estruturais das paredes celulares das forragens, tais como os ácidos graxos voláteis (AGV). Baldizán et al. (1986) determinaram que existem altas concentrações de $\mathrm{AGV}$ no ceco. $\mathrm{O}$ acetato é encontrado em maior proporção, sendo que este valor tende a aumentar em dietas com maior quantidade de forragem. $\mathrm{O}$ butirato foi o AGV presente em menor quantidade, como na maioria dos herbívoros (exceto coelhos). Os ácidos graxos voláteis parecem ser absorvidos no intestino grosso (Parra, 1977; Baldizán et al., 1986).

A eficiência energética da capivara ainda não foi medida. Seu calor corporal em relação ao seu peso corporal é $17 \%$ menor do que a média interespecífica $(0,45 \%$ contra $0,55 \%)$ o que parece indicar uma baixa taxa de metabolismo basal. Isso explicaria porque a capivara acumula facilmente gordura na estação chuvosa nos llanos da Venezuela, quando há bastante forragem disponível, enquanto o gado bovino não engorda , é provavelmente, devido a menores exigências energéticas para a manutenção (González-Jiménez \& Parra, 1973).

Ojasti (1973) estimou em $1.042 \mathrm{kcal} /$ dia a energia basal de uma capivara com $40 \mathrm{~kg}$ de peso vivo, e a necessidade de cerca de $1.320 \mathrm{kcal} / \mathrm{dia}$ de energia digestível para manutenção deste animal. Em um estudo sobre capacidade de carga nas savanas de Apure, Venezuela, Ojasti (1978) determinou que o consumo diário de um grupo de 12 capivaras/ha era de cerca de $203 \mathrm{kcal} / \mathrm{m}^{2}$ por ano, o que equivaleria a somente $3,5 \%$ da produção primária líquida daquele ecossistema. 
Na natureza, é o conteúdo protéico aliado à palatabilidade que define a seletividade e a preferência da capivara por determinadas espécies de gramíneas (Ojasti, 1973;González-Jiménez \& Escobar, 1977). Ojasti (1973) determinou, em um experimento de preferência alimentar, que as capivaras consumiam mais forragens que tinham em média 9,92\% de PB e $3.880 \mathrm{kcal}$ de energia bruta/kg. Esses valores são semelhantes aos determinados por GonzálezJiménez (1977), que relatou que a média de proteína bruta dos vegetais consumidos pela capivara na natureza é de cerca de $9,23 \%$, sendo que mais de $50 \%$ do consumo total de volumoso foi atribuído às espécies Hymenachne amplexicaulis. e Leersia hexandra (gramíneas baixas, de hábito aquático e de alto teor protéico).

Alguns trabalhos têm sido feitos com capivaras em cativeiro para determinar o consumo diário, o tipo de alimentação, a ingestão diária protéica e energética, níveis de proteína na ração, proporção de concentrado e volumosos a serem fornecidos, conversão alimentar e ganho de peso para animais de diferentes categorias de peso. Ojasti (1973) determinou um consumo de 1,7 kg de gramíneas frescas e $440 \mathrm{~g}$ de MS por dia para animais jovens, sendo que um adulto consumiria em torno de 3 a $4 \mathrm{~kg}$ de forragem seca. Alho (1986) estimou um consumo de $5 \mathrm{~kg}$ de capim fresco por animal por dia. Parra \& González-Jiménez (1971) relataram um consumo de 829 g de MS/dia para animais com média de 15 $\mathrm{kg}$ de peso vivo médio.

Baldizán et al. (1986) em experimento para estudar o processo fermentativo da capivara registraram um consumo de $570 \mathrm{~g}$ de $\mathrm{MS} / \mathrm{dia}(8,1 \%$ de proteína e $71,1 \%$ de parede celular) para animais adultos alimentados com Pennisetum purpureum, fresco e picado, e um consumo de $551 \mathrm{~g}$ de MS/dia para animais alimentados com uma ração com 16,3 \% de PB. Baldizán et al. (1982) observaram, para animais de 18 a $25 \mathrm{~kg}$ de PV, um consumo de $400 \mathrm{~g}$ de $\mathrm{MS} / \mathrm{dia}$ 
de feno de Cenchrus ciliares (11,6\% PB), 476 g de MS/dia de ração com $15 \%$ de farinha de mandioca $(8,9 \%$ PB) e $518 \mathrm{~g}$ de $\mathrm{MS} /$ dia de ração com $30 \%$ de farinha de mandioca (8,4\% de PB). Parra (1976) relatou um ganho diário de peso (GDP) de 90 e 85 g para machos e fêmeas, respectivamente, com peso médio de $11,0 \pm 2,6 \mathrm{~kg}$ tratados com uma dieta de $70 \%$ de Pennisetum purpureum (aproximadamente 6,3\% de $\mathrm{PB}$ e $1.920 \mathrm{kcal}$ de $\mathrm{EB} / \mathrm{kg}$ ) e $30 \%$ de uma ração com $14 \%$ de $\mathrm{PB}$, sendo que os maiores ganhos de peso e as melhores conversões alimentares foram observadas até os $20 \mathrm{~kg}$ de PV.

Parra et al. (1978) observaram um GDP de 127,2 g para animais de 14-21 kg de PV alimentados com 50\% de capim elefante e $50 \%$ de ração com 14\% de PB; GDP de 89,3 g para animais de $22-27 \mathrm{~kg}$ tratados com 50\% de capim elefante e $50 \%$ de ração com $18 \%$ de PB e um GDP de 40,6 g para animais de 16$19 \mathrm{~kg}$ que alimentados somente com capim elefante. Em outro experimento, esses mesmos autores obtiveram os seguintes resultados para dietas de $100 \%$ capim elefante, $56 \%$ de capim $+44 \%$ de ração com $18 \%$ de PB e $43 \%$ de capim $+57 \%$ de ração com $14 \%$ de PB, respectivamente: GDP de 39,5 , 110,0 e 91,8 g; consumo diário de 81,6 , 69,8 e 78,4 /kg de peso metabólico (PM); e conversão alimentar de 19,5:1, 7,5:1 e 7,4:1.

Lavorenti (1989) obteve ganhos diários de 106,62, 107,32 e 111,54 g para capivaras em crescimento alimentadas com rações contendo 12, 15 e $18 \%$ de PB mais capim elefante (Pennisetum purpureum, com 2,6\% de PB e $1.200 \mathrm{kcal} / \mathrm{kg}$ de MS) ad libitum. Silva Neto (1989) obteve para capivaras, com peso vivo médio acima de $20 \mathrm{~kg}$, alimentadas com capim elefante e rações de $13,5,17$ e $20,5 \%$ de $\mathrm{PB}$ e $3.880 \mathrm{kcal}$ de $\mathrm{EB} / \mathrm{kg}$, respectivamente, os seguintes valores: $\mathrm{GDP}=105,35,106,34$ e 110,91 g; consumo diário de $\mathrm{MS}=1120,66$, $1123,43 \mathrm{~g}$ e 1075,01 g; consumo diário por kg de peso metabólico $=86,97,84,46$ e $82,3 \mathrm{~g} / \mathrm{kg}$; conversão alimentar $=13,62: 1,13,90: 1$ e 13,09:1, não havendo 
diferença estatística entre os tratamentos. Em outro experimento, este mesmo autor determinou um GDP de 129,76 g, com consumo de 582,45 g de MS e conversão de 12,40:1 para animais alimentados com uma ração de 17\% de PB e $4.193 \mathrm{kcal}$ de EB/kg mais capim elefante ad libitum, sendo que para animais que receberam apenas a ração de 17\%PB ad libitum o GDP foi de 100,1 1g, com um consumo diário de MS de 588,50 g e uma conversão alimentar de 6,69:1.

González-Jiménez \& Escobar (1975) determinaram que capivaras com $24,49 \pm 3,24 \mathrm{~kg}$ de PV e um consumo de $444 \pm 61 \mathrm{~g}$ de MS/dia de diferentes proporções $(0: 100,25: 75,50: 50,75: 25$ e $100: 0)$ de concentrado com $17,2 \%$ de $\mathrm{PB}$ e feno, respectivamente, tiveram uma ingestão de $411 \mathrm{mg}$ de N/kg de peso metabólico ou $30 \mathrm{~g}$ de proteína/animal/dia. Vasey (1979) observou que filhotes alimentados diariamente com $130 \mathrm{~g}$ de proteína e $2.200 \mathrm{Cal}$, obtiveram um GDP de $119 \mathrm{~g}$, consumindo $1,1 \mathrm{~g}$ de proteína e $18 \mathrm{Cal}$ para cada grama de ganho de peso. Em outro experimento este autor obteve um GDP de $134 \mathrm{~g}$, com o consumo de $0,5 \mathrm{~g}$ de proteína e $10 \mathrm{Cal}$ para cada grama de ganho de peso.

A Tabela 4 resume os principais trabalhos com níveis e consumo de proteína em dietas para capivaras com seus respectivos GDP, consumo diário, conversão alimentar e categoria de peso dos animais. 
Tabela 4 : Categorias de peso, tipo de dieta, nivel protéico, consumo, GDP e conversão alimentar de capivaras (H.h.hydrochaeris).

\begin{tabular}{|c|c|c|c|c|c|c|}
\hline $\begin{array}{l}\text { Au } \\
\text { to } \\
\text { res }\end{array}$ & $\begin{array}{l}\text { Categoria do } \\
\text { animal em } \\
\text { peso (kg) }\end{array}$ & Tipo de dieta & Nível Protéico & $\begin{array}{l}\text { Consumo } \\
\text { diário }\end{array}$ & GDP & $\begin{array}{l}\text { Conver- } \\
\text { são } \\
\text { Alimen- } \\
\text { tar }\end{array}$ \\
\hline 1 & $24.49 \pm 3,24$ & Feno+Concentrado de $17.2 \% \mathrm{~PB}$ & $\begin{array}{c}30 \mathrm{~g} \mathrm{de} \\
\text { prot./animal } \\
/ / \mathrm{dia}\end{array}$ & $444 \mathrm{~g}$ & - & - \\
\hline 2 & $11.0 \pm 2.6$ & $\begin{array}{c}\text { Capim elefante + ração com } \\
15 \% \mathrm{~PB}-(70: 30)\end{array}$ & $6,6 \% \mathrm{~PB}$ & & $85-90$ & \\
\hline 3 & $\begin{array}{l}14-21 \\
22-27\end{array}$ & $\begin{array}{l}\text { Capim+raçãol 8\%PB- (50:50) } \\
\text { Capim + ração 18\%PB-(50:50) }\end{array}$ & & & $\begin{array}{l}127.2 \\
89,3\end{array}$ & \\
\hline 3 & & $\begin{array}{l}\text { Capim+raçãol 8\%PB -(56:44) } \\
\text { Capim+ração 14\%PB - (43:57) }\end{array}$ & & $\begin{array}{c}69,8 \mathrm{~g} / \mathrm{kg} \\
\text { de } \mathrm{PM} \\
78,4 \mathrm{~g} / \mathrm{kg} \\
\text { de } \mathrm{PM}\end{array}$ & 91,8 & 7,4:1 \\
\hline 4 & filhotes até $4 \mathrm{lkg}$ & $\begin{array}{l}\text { Variada (capim. verduras. } \\
\text { tubérculos. concentrado) }\end{array}$ & $130 \mathrm{~g}$ de prot./dia & & $\begin{array}{l}119- \\
134\end{array}$ & \\
\hline 5 & $18-25$ & $\begin{array}{c}\text { Feno (Cenchrus ciliares) } \\
\text { Feno }+15 \% \text { de farinha de } \\
\text { mandioca }\end{array}$ & $\begin{array}{l}11,6 \% \mathrm{~PB} \\
8,9 \% \mathrm{~PB}\end{array}$ & $\begin{array}{l}400 \mathrm{~g} \\
476 \mathrm{~g}\end{array}$ & & \\
\hline 6 & & $\begin{array}{l}\text { Capim elefante } \\
\text { Ração }\end{array}$ & $\begin{array}{c}8.1 \% \mathrm{~PB} \\
16,3 \% \mathrm{~PB}\end{array}$ & $\begin{array}{l}570 \mathrm{~g} \\
551 \mathrm{~g}\end{array}$ & & \\
\hline 7 & $20-40 \mathrm{~kg}$ & $\begin{array}{c}\text { Capim+concentrado - }(80: 20) \\
\text { Ração }\end{array}$ & $\begin{array}{l}12 \% \mathrm{~PB} \\
15 \% \mathrm{~PB} \\
18 \% \mathrm{~PB}\end{array}$ & $4,1 \% \mathrm{PV}$ & $\begin{array}{l}109,8 \\
106,6 \\
107,3 \\
111,5\end{array}$ & $8.65: 1$ \\
\hline 8 & acima de $20 \mathrm{~kg}$ & Ração + capim & $\begin{array}{c}13,5 \% \mathrm{~PB} \\
17 \% \mathrm{~PB} \\
20.5 \% \mathrm{~PB} \\
17\end{array}$ & $\begin{array}{c}1120,66 \mathrm{~g} \\
1123,43 \mathrm{~g} \\
1075,01 \mathrm{~g} \\
588,50\end{array}$ & $\begin{array}{l}105,3 \\
106,3 \\
110,9 \\
100,1\end{array}$ & $\begin{array}{c}13,62: 1 \\
13,90: 1 \\
13,09: 1 \\
6,69: 1\end{array}$ \\
\hline 9 & $\begin{array}{c}2,6-17,16 \\
17,16-32,28 \\
32.28-47,36\end{array}$ & $\begin{array}{l}\text { Ração 14\%PB+capim } \\
\text { Ração 14\%PB+capim } \\
\text { Ração 14\%PB+capim }\end{array}$ & & $\begin{array}{r}296,4 \\
741,6 \\
1194.6\end{array}$ & $\begin{array}{l}80,89 \\
81,72\end{array}$ & $\begin{array}{c}3,7: 1 \\
9,1: 1 \\
28,9: 1\end{array}$ \\
\hline
\end{tabular}

FONTE: 1-González-Jiménez \& Escobar (1975); 2-Parra (1976); 3-Parra et al..(1978); 4-Vasey (1979);5-Baldizán et al.(1982); 6-Baldizán et al. (1986); 7-Lavorenti (1989): 8-Silva Neto (1989): 9-Adaptado de Andrade et al.(1996). 


\section{MATERIAL E MÉTODOS}

\subsection{Materiais :}

3.1.1. Animais: foram utilizados 64 filhotes de capivara (H. hydrochaeris hydrochaeris) de 70 e 150 dias de idade, com peso médio de 8,24 $\pm 2,13$ e 9,97 \pm $2,14 \mathrm{~kg}$, respectivamente.

3.1.2. Ração Experimental: foram utilizados dois níveis de proteína bruta $(13,5$ e 20,0 \%) - o menor e o maior usados por Silva Neto (1989) - e dois níveis de energia bruta $(4.000$ e $4.500 \mathrm{kcal} / \mathrm{kg})$. Os níveis de EB foram baseados nas exigências determinadas para capivaras em vida livre por Ojasti (1973), para capivaras em cativeiro, por Vasey (1979), Lavorenti (1989), Silva Neto (1989) e Albuquerque (1993), e para suínos em crescimento (Campos, 1981;Rostagno et al., 1994). As quatro rações, que constituíram os tratamentos, tiveram as seguintes composições percentuais e químico-bromatológicas (Tabelas 5 e 6): 
Tabela 5 : Composição percentual das rações experimentais.

\begin{tabular}{|c|c|c|c|c|}
\hline INGREDIENTES & $\begin{array}{c}\text { Tratamento } 1 \\
\mathrm{~PB}=13,5 \% \\
\mathrm{~EB}=4.000 \\
\mathrm{kcal} / \mathrm{kg}\end{array}$ & $\begin{array}{c}\text { Tratamento } 2 \\
\mathrm{~PB}=20,0 \% \\
\mathrm{~EB}=4.000 \\
\mathrm{kcal} / \mathrm{kg}\end{array}$ & $\begin{array}{c}\text { Tratamento } 3 \\
\mathrm{~PB}=13,5 \% \\
\mathrm{~EB}=4.500 \\
\text { kcal/kg }\end{array}$ & $\begin{array}{c}\text { Tratamento } 4 \\
\text { PB }=20,0 \% \\
\mathrm{~EB}=4.500 \\
\text { kcal/kg }\end{array}$ \\
\hline Milho & 81,54 & 59,79 & 81,41 & 59,66 \\
\hline Farelo de Soja & 13,35 & 33,13 & 13,35 & 33,13 \\
\hline $\begin{array}{l}\text { Feno de Coast cross } \\
\text { (Cynodon spp.) }\end{array}$ & 1,33 & 3,42 & 1,33 & 3,42 \\
\hline Fosfato Bicálcico & 2,93 & 2,94 & 2,93 & 2,94 \\
\hline Calcário & 0,19 & 0,08 & 0,19 & 0,08 \\
\hline Sal & 0,40 & 0,40 & 0,40 & 0,40 \\
\hline Premix Vitamínico 1 & 0,13 & 0,13 & 0,13 & 0,13 \\
\hline Premix Mineral $^{2}$ & 0,13 & 0,13 & 0,13 & 0,13 \\
\hline TOTAL & 100 & 100 & 100 & 100 \\
\hline Óleo de Soja & -- & -- & $56 \mathrm{~g} / \mathrm{kg}$ & $56 \mathrm{~g} / \mathrm{kg}$ \\
\hline
\end{tabular}

1 - Premix Vitamínico (em $1 \mathrm{~kg}$ de premix) : vit. $\mathrm{A}=12.000 .000 \mathrm{UI} ; \mathrm{D} 3=1.500 .000 \mathrm{UI} ; \mathrm{E}=$ $15.000 \mathrm{UI} ; \mathrm{B} 1=2 \mathrm{~g} ; \mathrm{B} 2=4 \mathrm{~g} ; \mathrm{B} 6=4 \mathrm{~g} ; \mathrm{B} 12=20.000 \mathrm{mcg}$; Pantotenato de $\mathrm{Ca}=15 \mathrm{~g}$; Biotina $=$ $0,1 \mathrm{~g}$; Vit. K3 $=3 \mathrm{~g}$; Ácido Fólico $=0,6 \mathrm{~g}$; Ácido Nicotínico $=20,0 \mathrm{~g}$; Bacitracina de Zinco $=20,0$ $\mathrm{g} ;$ Selênio $=0,1 \mathrm{~g} ; \mathrm{L}$ - lisina $=300 \mathrm{~g} ; \mathrm{BHT}=10 \mathrm{~g}$

2 - Suplemento Mineral (em l kg de premix) $: \mathrm{Fe}=180 \mathrm{~g} ; \mathrm{Cu}=20 \mathrm{~g} ; \mathrm{Co}=4 \mathrm{~g} ; \mathrm{Mn}=80 \mathrm{~g} ; \mathrm{Zn}=$ $140 \mathrm{~g} ; \mathrm{I}=4 \mathrm{~g}$ 
Tabela 6 : Composição químico-bromatológica das rações experimentais :

\begin{tabular}{|c|c|c|c|c|}
\hline \multirow[t]{2}{*}{ NUTRIENTES } & \multicolumn{2}{|c|}{$\begin{array}{c}\text { Energia Bruta }=4.000 \\
\mathrm{kcal} / \mathrm{kg}\end{array}$} & \multicolumn{2}{|c|}{$\begin{array}{c}\text { Energia Bruta }=4.500 \\
\mathrm{kcal} / \mathrm{kg}\end{array}$} \\
\hline & $\begin{array}{c}\mathrm{T} 1 \\
(13,5 \% \mathrm{~PB})\end{array}$ & $\begin{array}{c}\mathrm{T} 2 \\
(20,0 \% \mathrm{~PB})\end{array}$ & $\begin{array}{c}\mathrm{T3} \\
(13,5 \% \mathrm{~PB})\end{array}$ & $\begin{array}{c}\text { T4 } \\
(20,0 \% \text { PB })\end{array}$ \\
\hline $\begin{array}{l}\text { Matéria seca à } \\
105^{\circ} \mathrm{C}\end{array}$ & 95,19 & 95,23 & 95,08 & 94,78 \\
\hline $\begin{array}{l}\text { Matéria } \\
\text { orgânica }^{1}\end{array}$ & 89,40 & 88,39 & 89,90 & 88,38 \\
\hline Proteína bruta $^{1}$ & 13,41 & 20,30 & 14,04 & 19,92 \\
\hline Fibra bruta ${ }^{1}$ & 3,01 & 3,76 & 2,86 & 3,52 \\
\hline Fib. detg. neutro ${ }^{1}$ & 15,60 & 15,93 & 19,22 & 20,60 \\
\hline Fib. detg. ácido ${ }^{1}$ & 4,98 & 5,90 & 5,23 & 5,95 \\
\hline Extrato etéreo ${ }^{1}$ & 1,61 & 1,78 & 2,38 & 2,13 \\
\hline Matéria mineral $^{1}$ & 5,79 & 6,84 & 5,18 & 6,40 \\
\hline $\begin{array}{l}\text { Extrativo não } \\
\text { nitrogenado }\end{array}$ & 71,37 & 63,15 & 70,62 & 62,81 \\
\hline Cálcio $^{1}$ & 1,12 & 1,13 & 1,15 & 1,16 \\
\hline Fósforo ${ }^{1}$ & 0,90 & 0,94 & 0,93 & 0,97 \\
\hline Energia Bruta ${ }^{2}$ & $3.950,90$ & $3.986,99$ & $4.453,10$ & $4.487,22$ \\
\hline
\end{tabular}

1. MS à $105^{\circ} \mathrm{C} ; 2$. kcal $/ \mathrm{kg}$ de $\mathrm{MS}$. 
3.1.3. Análises bromatológicas : foram realizadas análises bromatológicas não apenas das rações que constituíram os tratamentos mas também das amostras de fezes e urina do ensaio de digestibilidade.

\subsubsection{Instalações :}

A) BAIAS EXPERIMENTAIS : Na primeira etapa deste estudo, os animais foram confinados (na densidade de $1 \mathrm{cab} / 20 \mathrm{~m}^{2}$ ) em 12 baias experimentais na área do projeto da Comissão de Investigação de Zootecnia e Biologia de Animais Silvestres (CIZBAS), no Departamento de Zootecnia da ESALQ / USP. Estas baias medem 4,0 $\mathrm{m} \times 10,0 \mathrm{~m}$, contendo um abrigo de alvenaria de tijolos coberto com telhas de amianto e medindo 2,0 $\mathrm{m} \mathrm{X} \mathrm{2,0} \mathrm{m,} \mathrm{tendo} \mathrm{piso} \mathrm{de} \mathrm{terra} \mathrm{e} \mathrm{um} \mathrm{tanque}$ de água em alvenaria (1,5 m X 1,5 m X 0,8 m). As baias são cercadas nas laterais e no fundo por alambrado de moirões de cimento e tela de malha quadrada de 2", fio de arame galvanizado n-12, com 1,4 m de altura, e na frente muro de alvenaria de tijolo (Figura 2).

Doze animais foram alojados em piquetes de $400 \mathrm{~m}^{2}$ (densidade de 1 cabeça/70 $\mathrm{m}^{2}$ ) a fim de que se pudesse comparar o desempenho das capivaras em crescimento em diferentes áreas de confinamento. Os piquetes são cercados com tela de alambrado de malha quadrada de 2,5 " e quatro fios arame farpado, atingindo uma altura de 1,6 m. Cada piquete possui um abrigo coberto com telhas de amianto para proteger os animais e os comedouros, são dotados também de tanques de água em alvenaria e árvores para sombreamento.

B) GAIOLAS METABÓLICAS : Na segunda etapa, foram utilizados os quatro animais mais adaptados (entre 10 que foram testados) para ficarem confinados 
individualmente em gaiolas metabólicas para o ensaio de digestibilidade das rações utilizadas na primeira etapa. As gaiolas utilizadas são gaiolas para bezerros $(1,63 \mathrm{~m} \times 1,04 \mathrm{~m})$, dotadas de tela de separação das fezes e coletor de urina, que foram adaptadas para a contenção de capivaras, conforme mostra a Figura 3 .

\subsection{Métodos :}

$\mathrm{O}$ trabalho foi dividido em duas fases. $\mathrm{Na}$ primeira fase (Experimento I) foi observado o desempenho dos animais em crescimento através da análise de ganho diário de peso (GDP), consumo diário, conversão alimentar e características de carcaça. O Experimento I foi dividido em três partes (A,B e C).

No Experimento I, parte A, foram analisados os efeitos de dois níveis de PB (13,5 e 20\%) e dois níveis de EB (4.000 e $4.500 \mathrm{kcal} / \mathrm{kg})$ em rações sobre o desempenho de capivaras em crescimento confinadas em baias experimentais ( 1 cabeça/20 $\left.\mathrm{m}^{2}\right)$.

Para analisar a influência do tamanho da área de confinamento e do tipo de dieta sobre capivaras em crescimento, foram utilizados os animais que sobraram da montagem da parte A, do Experimento I, e realizou-se o ensaio que constituiu a parte B do Experimento I.

$\mathrm{Na}$ parte $\mathrm{B}$, esses animais, de peso e idades similares, foram distribuídos em grupos que receberam os seguintes tratamentos : $\mathrm{Gl}=$ confinamento em baias ( 1 cabeça/20 $\mathrm{m}^{2}$ ) e ração peletizada (utilizaram-se os dados dos animais da parte A, do Experimento I ); G2 $=6$ animais confinados em baias experimentais ( 1 cabeça/ $20 \mathrm{~m}^{2}$ ) recebendo apenas capim elefante 
(Pennisetum purpureum) fresco com 8,82\% de PB e 35,52 \% de FB na MS; G3= 6 animais semiconfinados ( 1 cabeça/ $70 \mathrm{~m}^{2}$ ) recebendo ração peletizada com 17 $\%$ de $\mathrm{PB}, 4200 \mathrm{kcal}$ de $\mathrm{EB} / \mathrm{kg}$ e de $3 \%$ de fibra bruta (FB); e $\mathrm{G} 4=6$ animais semiconfinados $\left(1\right.$ cabeça $/ 70 \mathrm{~m}^{2}$ ) recebendo capim elefante mais ração farelada à base de rolão de milho e farelo de soja com cerca de $18 \%$ de PB, $3.300 \mathrm{kcal}$ de $\mathrm{EB} / \mathrm{kg}$ e $16,5 \%$ de FB. Cada animal dos diferentes grupos foi considerado uma unidade experimental. As variáveis analisadas foram as mesmas da parte A do Experimento I.

$\mathrm{Na}$ parte $\mathrm{C}$ do Experimento I, analisou-se o desempenho dos animais da parte A de acordo com a idade em que eles foram levados para as baias experimentais e começaram a receber ração. As variáveis observadas foram GDP, consumo diário e conversão alimentar.

$\mathrm{Na}$ segunda fase (Experimento II) realizou-se um ensaio de digestibilidade em gaiolas metabólicas, dos quatro tipos de rações usadas na parte A do Experimento I. 


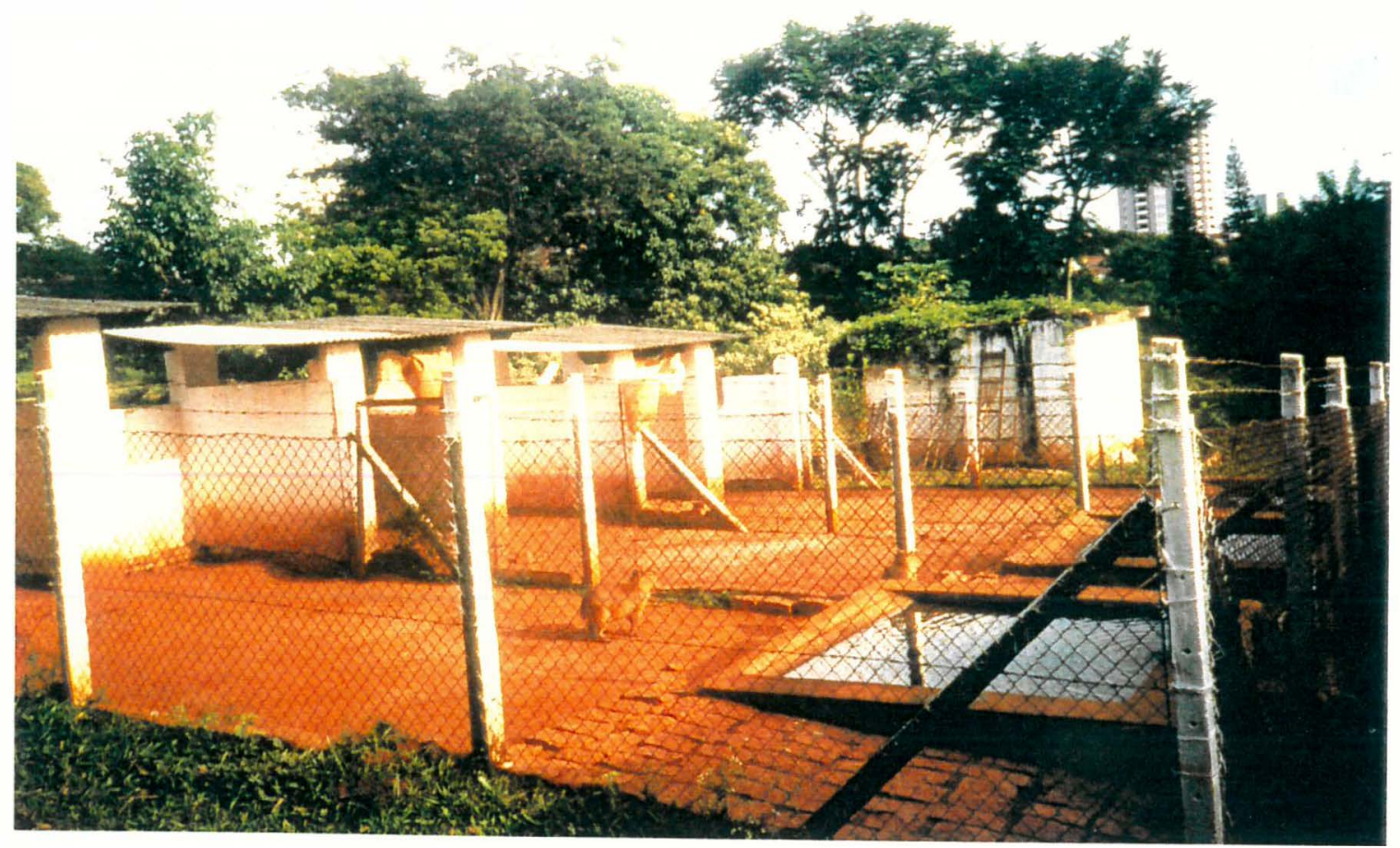

Figura 2: Baias experimentais .

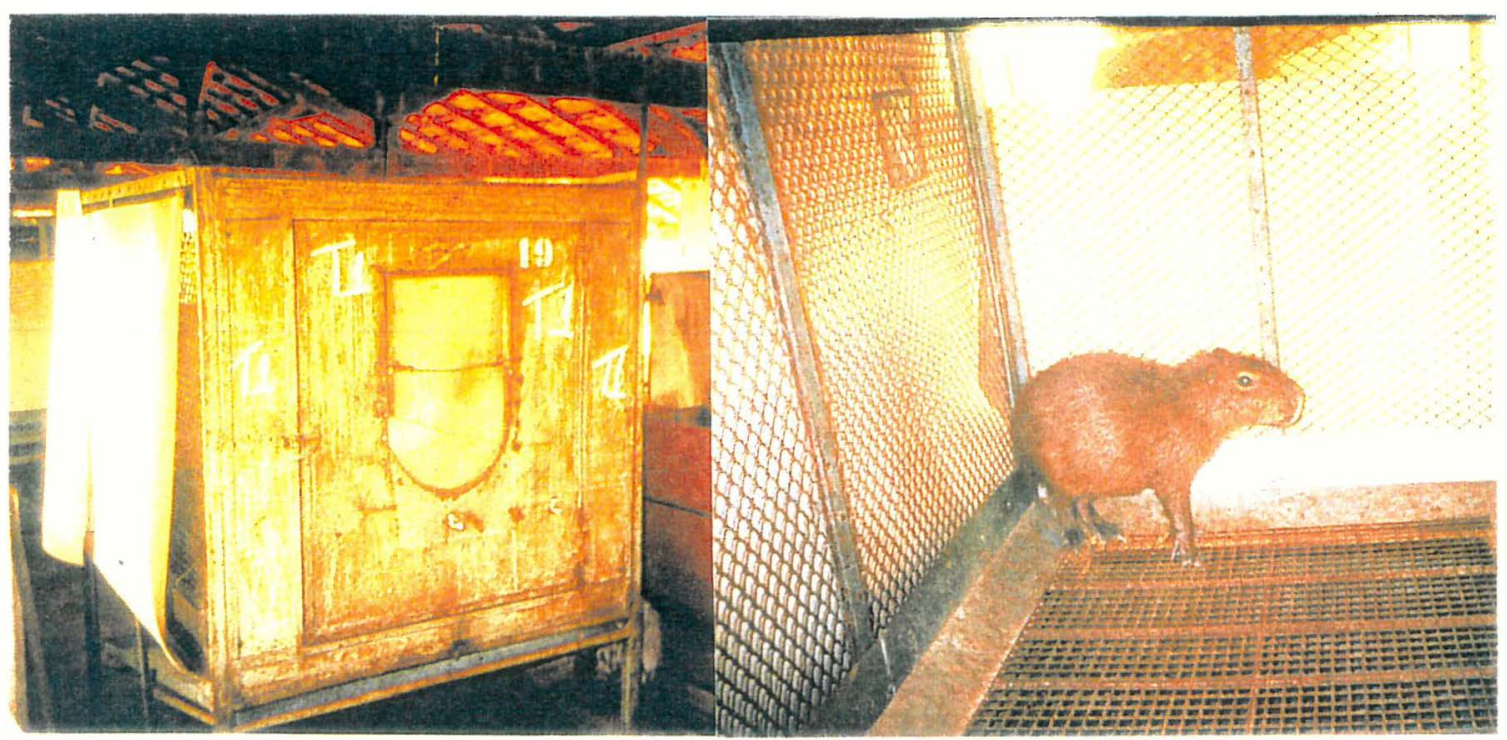

Figura 3 : Gaiolas metabólicas utilizadas no ensaio de digestibilidade. 


\subsubsection{Delineamento experimental :}

$\mathrm{Na}$ parte A do Experimento I, os tratamentos foram distribuídos em um delineamento aleatorizado em blocos, em um esquema fatorial $2 \times 2$, com dois níveis de PB (13,5 e $20 \%$ ) e dois níveis de EB (4.000 e $4.500 \mathrm{kcal} / \mathrm{kg}$ ). Os blocos foram montados de acordo com o peso e a idade dos animais. Não houve separação por sexo devido a dificuldade de se obter o número suficiente de filhotes, em cada período, que permitisse tal divisão, além disso segundo Parra et al.(1978) e Albuquerque (1993) não existem diferenças significativas no desenvolvimento de machos e fêmeas.

Foram feitas 5 repetições de cada tratamento, somando um total de 5 blocos montados ao longo do tempo: 2 blocos (I e II) no primeiro período de reprodução, em maio de 1994; e 3 blocos (III, IV e V) no segundo período, de novembro à janeiro de 1995. Cada repetição foi constituída de uma dupla de animais (fềmeas ou machos ou um casal). Isto foi feito devido a influência que o hábito gregário das capivaras poderia vir a ter sobre o consumo .

Na parte B do Experimento I, para comparar o desempenho entre animais que receberam as rações peletizadas experimentais confinados $(1 \mathrm{cb} / 20$ $\mathrm{m}^{2}$ ) nas baias experimentais, animais confinados que receberam somente capim, animais semiconfinados ( 1 cabeça/70 $\mathrm{m}^{2}$ ) em piquetes que receberam uma mistura das rações experimentais e os que receberam capim mais a ração farelada comum do projeto da CIZBAS, cada um destes grupos de animais foi considerado como recebendo diferentes tratamentos, G1, G2, G3 e G4, respectivamente. O grupo G1 foi constituído pelos animais que estavam participando dos blocos III,

IV e V da parte A do Experimento I. Consideraram-se os tratamentos como distribuídos inteiramente ao acaso, sendo cada animal considerado uma repetição. 
Na parte C do Experimento I, foram utilizados os dados de GDP, consumo diário e conversão alimentar dos animais da parte A do Experimento I. Os dados foram separados em dois grupos os dos blocos I e II, dos animais que entraram no experimento com 150 dias de idade, e os dos blocos III e IV, das capivaras que entraram com 70 dias.

$\mathrm{Na}$ análise dos dados da parte $\mathrm{C}$, estes foram rearranjados como em um delineamento aleatorizado em blocos. As idades (70 e 150 dias) foram consideradas os tratamentos. Cada tratamento da parte A passou a constituir um bloco, totalizando 8 blocos ( 2 blocos do Experimento I-A X 4 tratamentos do Experimento I-A) ou 8 repetições para cada tratamento da parte C. Foi utilizada, também, uma outra forma de análise, reunindo-se os dados da parte $\mathrm{A}$ em dois grupos de acordo com a idade inicial, sendo estes comparados através do teste $\mathrm{t}$ não-pareado.

O Experimento II teve delineamento tipo quadrado latino $4 \mathrm{X} 4$, com quatro animais passando por todos os tratamentos em quatro períodos de coleta. Os animais, 4 machos, foram confinados em gaiolas metabólicas, tendo idade e peso similares aos animais utilizados no Experimento I. As fêmeas não se adaptaram as gaiolas metabólicas, sofrendo estresse intenso e forte diarréia . Cada animal recebeu os quatro tratamentos ao longo do tempo, com um intervalo de duas semanas entre cada ensaio de digestibilidade.

\subsubsection{Tratamentos :}

$\mathrm{Na}$ parte A do Experimento I foram testadas quatro dietas, correspondentes aos quatro tratamentos a saber : 
- TRATAMENTO 01 : 13,5 \% de Proteína Bruta e 4.000 kcal de Energia Bruta;

- TRATAMENTO 02 : 20,0 \% de Proteína Bruta e 4.000 kcal de Energia Bruta;

- TRATAMENTO 03 : 13,5 \% de Proteína Bruta e 4.500 kcal de Energia Bruta;

- TRATAMENTO 04 : 20,0 \% de Proteína Bruta e 4.500 kcal de Energia Bruta.

Na parte B do Experimento I, foram analisados os efeitos de dois tamanhos da área de confinamento e de três tipos de dietas, que constituíram quatro tratamentos estudados segundo o quadro de contrastes da Tabela 7.

Tabela 7: Tratamentos da parte B do Experimento I.

\begin{tabular}{|c|c|c|}
\hline $\begin{array}{c}\text { Tamanho da área } \\
\text { - Densidade } \\
\end{array}$ & \multirow[t]{2}{*}{$\begin{array}{c}\text { Confinado } \\
\left(1 \text { cabeça/20 } \mathrm{m}^{2}\right)\end{array}$} & \multirow[t]{2}{*}{$\begin{array}{l}\text { Semiconfinado } \\
(1 \text { cabeça/70 m²) }\end{array}$} \\
\hline Tipo de dieta & & \\
\hline $\begin{array}{l}\text { - Capim elefante } \\
\text { - Capim + ração } \\
\text { farelada }\end{array}$ & $\mathrm{G} 2$ & G4 \\
\hline -Ração peletizada & G1 & G3 \\
\hline
\end{tabular}

Na parte C do Experimento I, considerou-se como tratamentos as duas diferentes idades em que as capivaras foram confinadas em baias e começaram a receber ração peletizada, 70 e 150 dias.

No Experimento II, determinou-se a digestibilidade das dietas testadas na parte A do Experimento I. 
O número de animais por tratamento foi o seguinte :

Experimento I - parte $A=10$ animais.

Experimento I - parte B - G2, G3 e G4 = 6 animais; G1= 12 animais.

Experimento I - parte $\mathrm{C}=16$ animais.

Experimento II $=1$ animal.

\subsubsection{Variáveis dependentes nos experimentos :}

\section{EXPERIMENTO I :}

- Ganho diário de peso (GDP) em gramas de peso vivo, medido quinzenalmente e por indivíduo;

- Consumo aparente (médio), em gramas e em percentual do peso vivo, medido diariamente;

- Conversão alimentar (média ), quinzenal;

- Os parâmetros de carcaça, medidos ao final do experimento com o abate de três animais de cada tratamento, foram os seguintes : peso vivo, perdas de peso, medidas lineares do animal, área de olho de lombo, rendimento de carcaça, cortes comerciais e dissecção física da carcaça (percentual de ossos, músculos e gordura). 


\section{EXPERIMENTO II :}

- Coeficientes de digestibilidade (individual), por tratamento: digestibilidade da matéria seca (DMS) em \% e digestibilidade dos nutrientes (DN) em \%.

\subsubsection{Condução dos experimentos :}

\section{EXPERIMENTO I :}

$\mathrm{Na}$ primeira fase, as dietas que constituíram os tratamentos do Experimento I, parteA e B, foram fornecidas diariamente, ad libitum, em uma base de $4 \%$ do peso vivo de cada animal, sendo que este fornecimento foi ajustado semanalmente de acordo com o consumo dos animais. O consumo foi medido através da pesagem diária das sobras no cocho.

Antes do início do período experimental, os animais receberam banho carrapaticida, através de pulverização à base de amitraz ${ }^{1}$, na diluição de 20 $\mathrm{ml} / 5 \mathrm{l}$ de água. Além do tratamento contra ectoparasitas, as capivaras do experimento também foram tratadas contra endoparasitas com um vermífugo oral, à base de febendazole ${ }^{2}$, na dosagem de $5 \mathrm{mg}$ de princípio ativo por quilo de peso vivo, ou com um produto injetável à base de cloridrato de levamisol a $7,5 \%{ }^{3}$, na dosagem de $2 \mathrm{ml}$ para cada $20 \mathrm{~kg}$ de peso vivo. Durante todo o período experimental foi feito o monitoramento das fezes dos animais, a fim de verificarse qualquer problema com endoparasitas.

Após 15 dias de adaptação às instalações experimentais e às dietas de cada tratamento, os animais passaram a ser pesados quinzenalmente. $\mathrm{O}$

\footnotetext{
${ }^{1}$ Triatox $\mathbb{}$

2 Panacur ${ }^{2}$

${ }^{3}$ Ripercol ${ }^{\circledR}$
} 
desempenho dos animais confinados nas baias experimentais que recebiam apenas capim, e dos animais alojados nos piquetes, também foi registrado.

Ao final do experimento, foram abatidos 3 animais de cada tratamento, com um intervalo de 14 dias, entre o primeiro e o último abate. Antes do abate foi feito um jejum de $24 \mathrm{~h}$, obtendo-se o peso vivo e o peso em jejum dos animais. $O$ peso do corpo vazio foi calculado pela diferença entre o peso em jejum e o conteúdo gastrointestinal.

O abate foi feito seguindo a metodologia do projeto da CIZBAS descrita por Albuquerque (1993), dividido em duas etapas : o atordoamento ou insensibilização, por concussão cerebral através de golpes de marreta, seguido de sangria pelo seccionamento da jugular, com posterior esfolamento do animal e retirada da cabeça e das patas. Após a esfola foi feita a evisceração e, em seguida, a carcaça foi serrada ao meio.

Os cortes comerciais foram feitos tomando por base os cortes de suínos e os cortes descritos para capivaras por Assaf \& Cruz (1976), Assaf et al. (1976), Godoy \& Gómez (1976) e Albuquerque (1993), já que ainda não existe uma padronização dos mesmos. Os cortes realizados foram os seguintes : pernil (desarticulado à altura da última vértebra lombar), lombo, filé, paleta, costela, acém e vazio. Os cortes comerciais foram medidos na meia carcaça esquerda. As Figuras 4 e 5 mostram a meia carcaça esquerda e os cortes comerciais. 


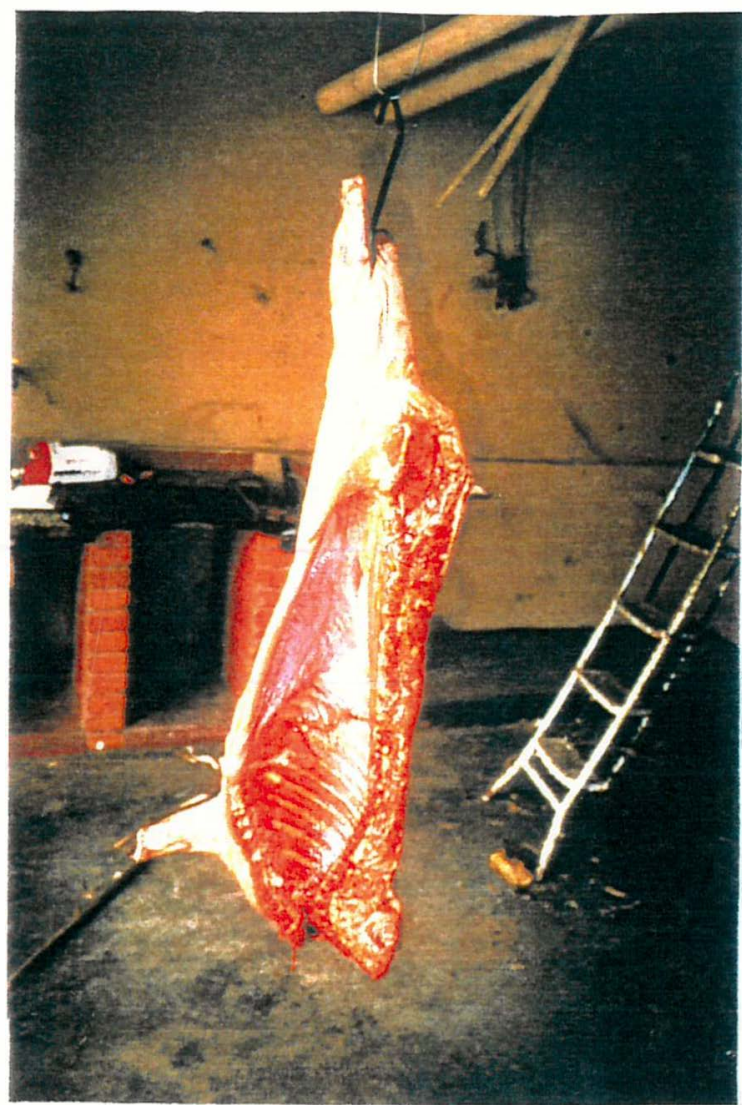

Figura 4 : Meia carcaça esquerda de capivara (H. h. hydrochaeris L. 1766)

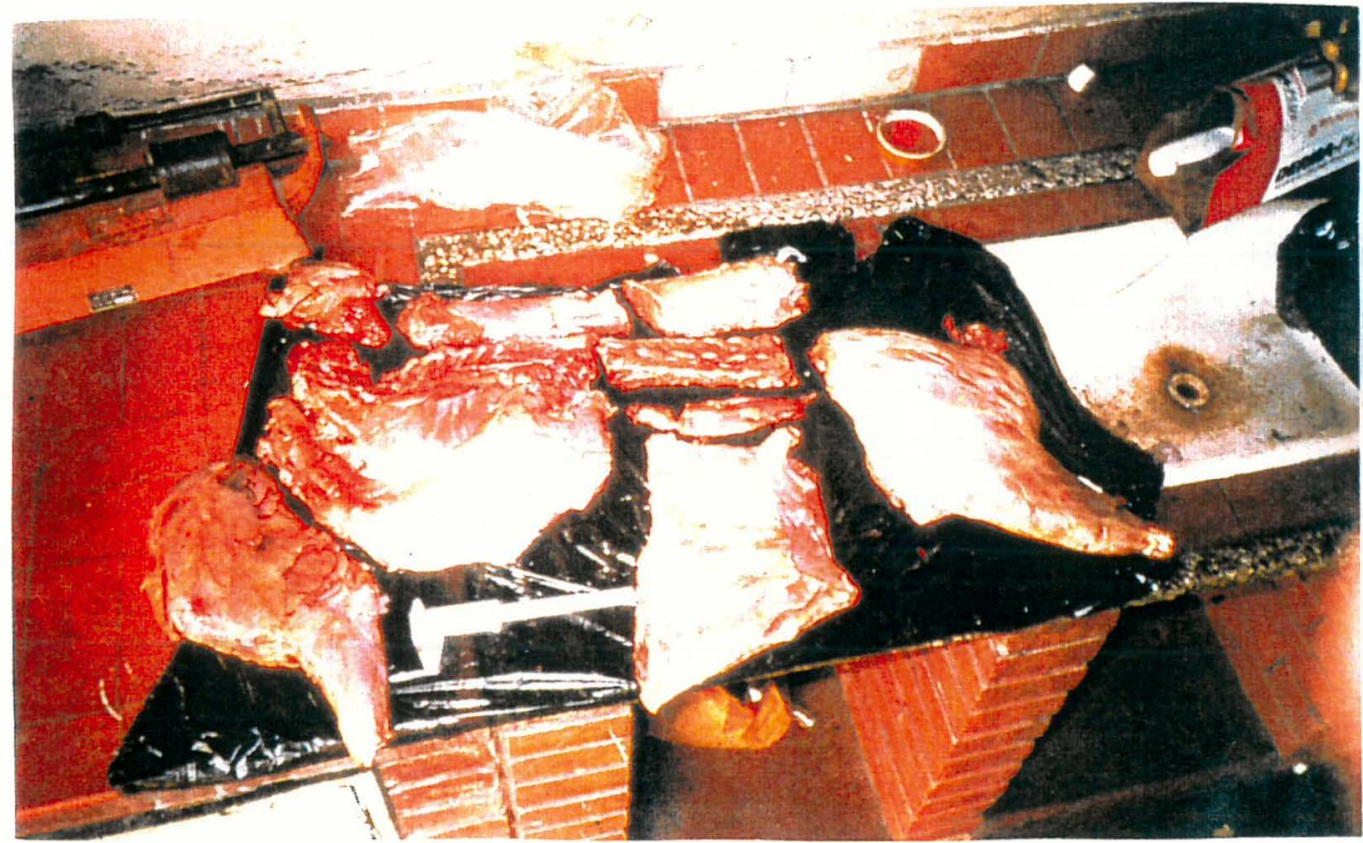

Figura 5: Cortes comerciais de capivara (H. h. hydrochaeris L., 1766). 
A dissecção física da carcaça em músculos, ossos e gordura foi feita na meia carcaça direita. Foi pesada também a gordura subcutânea, retirada na limpeza do couro.

\section{EXPERIMENTO II :}

Nas gaiolas metabólicas, os animais passaram por duas semanas de adaptação às novas condições. Neste período foram feitos todos os ajustes e aferições necessárias para a condução do ensaio de digestibilidade, que foi feito em um período de 5 dias de coleta (acima disto os animais começavam a apresentar problemas). Nos 3 últimos dias de adaptação foi feito uma restrição do consumo a aproximadamente $90 \%$ do menor consumo verificado, entre os animais, nos últimos dias de consumo ad libitum nas gaiolas.

Durante o ensaio de digestibilidade foi feita a coleta total das fezes e da urina duas vezes por dia, 6:00 e 18:00 horas, horários em que foi verificado também o consumo de água e de ração. As rações experimentais e a água eram fornecidas duas vezes por dia, por ocasião das coletas (fornecimento pela tarde e complementação pela manhã).

Mesmo selecionando os animais que mais se adaptavam às condições da gaiola metabólica, estes ainda apresentavam alto grau de estresse quando confinados nas mesmas, problema que foi atenuado através da utilização de florais de Bach, Rescue, fornecido na água do bebedouro (duas gotas) todos os dias durante os dois primeiros períodos experimentais do ensaio (Miranda ${ }^{1}$ ). O uso deste medicamento acalmava os animais e evitava a diarréia devido ao estresse.

\footnotetext{
${ }^{1}$ LUCIANA BATALHA DE MIRANDA, Veterinária do projeto da CIZBAS/ESALQ/USP, durante o período do experimento. 1995. Informação Pessoal.
} 
No Experimento II foram coletadas amostras diárias das rações, que, depois de homogeneizadas em uma amostra composta, foi guardada sob refrigeração até a realização das análises bromatológicas. No caso das fezes, todo material coletado foi pesado e, a cada coleta, metade do volume foi amostrada, acondicionada em saco plástico e armazenada a $-20{ }^{\circ} \mathrm{C}$. Ao final do período experimental as fezes foram descongeladas, homogeneizadas e levadas para a análise.

A urina foi recolhida em vidros colocados sob os coletores e seu volume medido em uma proveta. Para evitar sua evaporação e a volatilização da amônia se colocou em cada vidro $10 \mathrm{ml}$ de ácido clorídrico diluído a $50 \%$. Do total de urina coletado retirou-se $20 \%$ para amostra que foi guardado sob refrigeração para análise posterior.

\subsubsection{Análises das rações, das fezes e da urina :}

Os métodos analíticos utilizados para a análise das fezes, da urina e das rações experimentais foram os descritos pela Association of Official Agricultural Chemists (A.O.A.C., 1980). A determinação dos níveis dos constituíntes da parede celular (FDA e FDN) foi realizada de acordo com o método descrito por Goering \& Van Soest(1970). 


\subsubsection{Análise dos resultados :}

Os dados obtidos nos Experimentos I e II foram tabulados em planilha do microsoft EXCEL 5.0 e analisados no programa SAS (Statistical Analysis System) de análises estatísticas.

\section{EXPERIMENTO I :}

Para os dados de desempenho (GDP, consumo diário de MS, consumo diário em \% do PV e conversão alimentar) da parte A do Experimento I foi utilizado o esquema fatorial ( 2 níveis de $\mathrm{PB}$ : 13,5 e 20\% X 2 níveis de $\mathrm{EB}$ : 4.000 e $4.500 \mathrm{kcal} / \mathrm{kg}$ ) de análise de variância com delineamento em blocos aleatorizados.

O modelo estatístico adotado foi o seguinte :

$\mathbf{Y i j z}=\mu+\alpha_{i}+\beta \mathbf{j}+(\alpha \beta)_{i j}+\mathbf{b}_{z}+\mathbf{e}_{i j z}$ em que,

$\mathrm{Y}_{\mathrm{ij} z}=$ valor obtido na parcela que recebeu o nível $\mathrm{i}$ do fator EB com o nível $\mathrm{j}$ do fator PB no bloco z;

$\mu=$ média dos dados ;

$\alpha_{i}=$ efeito principal do nível i do fator EB;

$\beta \mathrm{j}=$ efeito principal do nível $\mathrm{j}$ do fator $\mathrm{PB}$;

$(\alpha \beta)_{\mathrm{ij}}=$ efeito da interação do nível i do fator EB com o nível j do fator PB;

$\mathrm{b}_{\mathrm{z}}=$ efeito do bloco $\mathrm{z}$;

$\mathrm{e}_{\mathrm{ijz}}=$ erro experimental.

Os dados de carcaça, dos animais das partes A e B do Experimento I, foram analisados ajustando-se as médias pelas cováriáveis peso do 
corpo vazio e peso da banda esquerda resfriada (no caso dos cortes comerciais), em um delineamento inteiramente aleatorizado. A análise dos dados dos animais do Experimento I, parte A seguiu o esquema fatorial de análise de variância.

O modelo estatístico utilizado para a análise de covariância foi o seguinte :

$\mathbf{Y}_{\mathrm{ijk}}=\mu+\alpha_{\mathrm{i}}+\beta \mathbf{j}+(\alpha \beta)_{\mathrm{ij}}+\mathbf{b}\left(\mathbf{X}_{\mathrm{ij}}-\mathbf{X}\right)+\mathbf{e}_{\mathrm{ijk}}$ em que,

$\mathrm{Y}_{\mathrm{i} \mathrm{j} \mathrm{k}}=$ valor obtido na parcela que recebeu o nível $\mathrm{i}$ do fator EB com o nível $\mathrm{j}$ do fator PB;

$\mu=$ média dos dados ;

$\alpha_{\mathrm{i}}=$ efeito principal do nível i do fator EB;

$\beta \mathbf{j}=$ efeito principal do nível $\mathbf{j}$ do fator $\mathrm{PB}$;

$(\alpha \beta)_{\mathrm{ij}}=$ efeito da interação do nível i do fator EB com o nível $\mathrm{j}$ do fator PB;

$\mathrm{b}=$ coeficiente de regressão linear entre $\mathrm{Y}$ e X;

$\mathrm{X}_{\mathrm{ij}}=$ covariável;

$\mathrm{X}=$ média da covariável ;

$\mathrm{e}_{\mathrm{ijk}}=$ erro experimental.

Para a comparação entre os diferentes tipos de alimentação e tamanho de área de confinamento, cada animal dos diferentes grupos (G1, G2, G3 e G4) do Experimento I, parte B, foi considerado uma repetição. Os dados de desempenho (GDP, consumo diário de MS, consumo diário em $\%$ do $\mathrm{PV}$ e conversão alimentar ) foram analisados em um modelo inteiramente casualizado. As médias de ganho diário de peso, consumo diário, conversão alimentar e características de carcaça foram comparadas através de contrastes ortogonais (teste F) e teste $\mathrm{t}$ (pelo LSMEANS do SAS). 
As médias de GDP, consumo diário de MS e conversão alimentar da parte $\mathrm{C}$ do Experimento I foram comparadas pelo teste $\mathrm{F}$ e pelo teste $\mathrm{t}$ não pareado (PROC TTEST do SAS).

\section{EXPERIMENTO II :}

Os dados do ensaio de digestibilidade das rações experimentais foram analisados segundo o delineamento de quadrado latino $4 \mathrm{X} 4$ (4 animais $\mathrm{X}$ 4 períodos). As médias de digestibilidade foram comparadas através de contrastes ortogonais pelo teste $\mathrm{F}$.

O modelo estatístico adotado foi o seguinte :

$\mathbf{Y}_{i j k z}=\mu+\alpha_{i}+\beta \mathbf{j}+(\alpha \beta)_{i j}+l_{k}+c_{\mathbf{z}}+\mathbf{e}_{i j k z}$ em que,

$\mathrm{Y}_{\mathrm{ijkz}}=$ valor obtido na parcela que recebeu o nível i do fator EB com o nível $\mathrm{j}$ do fator PB na linha $\mathrm{k}$ da coluna $\mathrm{z}$;

$\mu=$ média dos dados;

$\alpha_{i}=$ efeito principal do nível i do fator EB;

$\beta \mathrm{j}=$ efeito principal do nível $\mathbf{j}$ do fator $\mathrm{PB}$;

$(\alpha \beta)_{\mathrm{ij}}=$ efeito da interação do nível i do fator EB com o nível j do fator PB;

$1_{\mathrm{k}}=$ efeito da linha (animal) $\mathrm{k}$;

$\mathrm{c}_{\mathrm{z}}=$ efeito da coluna (período) $\mathrm{z}$;

$\mathrm{e}_{\mathrm{ijkz}}=$ erro experimental. 


\section{RESULTADOS E DISCUSSÃO}

\subsection{Experimento I-A:Níveis de proteína e energia bruta na ração:}

Os quadros de análise de variância das variáveis estudadas no Experimento I são mostrados no Apêndice 1.

\subsubsection{Ganho de peso :}

A Tabela 8 apresenta os resultados obtidos em ganhos médios diários de peso (GDP) para capivaras em crescimento submetidas a rações com diferentes níveis de proteína bruta (PB), 13,5 e 20,0 \%, e de energia bruta (EB), 4.000 e $4.500 \mathrm{kcal} / \mathrm{kg}$. Não houve diferença estatística significativa $(\mathrm{p}>0,05)$, pelo teste $\mathrm{F}$, entre os níveis de $\mathrm{PB}$ e $\mathrm{EB}$ e suas interações para esta variável. Os animais apresentaram durante os períodos experimentais ganhos médios diários de 70,05 $\pm 9,46 \mathrm{~g}$, sendo o menor valor médio por tratamento igual a 59,04 g/dia e o maior $81,05 \mathrm{~g} / \mathrm{dia}$. 
Tabela 8 : Efeito de níveis de $\mathrm{PB}$ e EB em rações sobre o ganho médio diário de peso (GDP) de capivaras em crescimento (g).

\section{Níveis de Energia Bruta}

Médias dos Níveis

de Proteína

Bruta $^{1}$

\begin{tabular}{|c|c|c|c|}
\hline Níveis de PB & $4.000 \mathrm{kcal} / \mathrm{kg}^{3 /}$ & $4.500 \mathrm{kcal} / \mathrm{kg}$ & 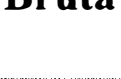 \\
\hline $13,5 \%^{4 /}$ & 66,42 & 59,04 & 62,73 \\
\hline $20,0 \%$ & 81,05 & 73,69 & 77,37 \\
\hline $\begin{array}{l}\text { Médias dos Níveis } \\
\text { de Energia Bruta }\end{array}$ & 73,73 & 66,36 & \\
\hline
\end{tabular}

$\mathrm{CV}=23,75 \%$

1- As médias dos níveis de $\mathrm{PB}$, na coluna, não diferem, estatisticamente, pelo teste $\mathrm{F}$ (Prob $>\mathrm{F}=0,07)$

2- As médias dos níveis de $E B$ não diferem, estatisticamente, pelo teste $F$ (Prob $>F=0,34$ ); 3/ e 4/ - A interação entre PB X EB para a variável GDP é, estatisticamente, não significativa pelo teste $\mathrm{F}$ (Prob > $\mathrm{F}=0,99$ ).

Apesar de não haver diferenças significativas $(p>0,05)$ entre $o$ GDP dos animais para os diferentes níveis de proteína bruta e energia bruta, é possível verificar uma tendência de maior ganho de peso médio diário com um maior nível de proteína na ração. Pode-se observar, também, que existe uma tendência à redução nos ganhos com as rações de maior nível energético (4.500 $\mathrm{kcal}$ de $\mathrm{EB} / \mathrm{kg})$.

Considerando-se que foram utilizados animais no período de maior velocidade de crescimento, portanto, no período de maior exigência protéica, e ainda que, procurou-se minimizar a heterogeneidade dos animais através do delineamento blocos casualizados, é possível serem inferidas algumas hipóteses sobre a não significância das diferenças entre o maior e o menor nível de proteína bruta.

Primeiramente, deve-se considerar que, apesar de terem sido montados blocos os mais uniformes possíveis, existia ainda uma variabilidade muito grande no potencial de ganho de peso entre os animais experimentais, visto 
que, nenhum processo efetivo de seleção artificial foi ainda exercido sobre esta espécie, mantendo-se ela, desta forma, com uma diversidade considerável em termos de desempenho (coeficiente de variação para o GDP $=23,75 \%$ no experimento). A diferença máxima entre os tratamentos foi de $22,01 \mathrm{~g} / \mathrm{dia}$, enquanto foi observado diferença de até $72,71 \mathrm{~g} /$ dia dentro dos tratamentos . Ainda com relação a variação existente, deve ser considerado que, em alguns animais do experimento, tornou-se clara a relação de dominância de um animal sobre o outro da dupla, em cada baia. O animal submisso, impedido de comer adequadamente, apresentava um desempenho bem inferior. Portanto, se for considerado o coeficiente de variação, pode-se dizer que existe diferença significativa a nível de $10 \%$, entre os níveis de PB.

Em segundo lugar, a capivara possui toda uma estratégia comportamental e fisiológica para manter o seu equilíbrio do balanço de nitrogênio. Logo, animais submetidos a dietas deficientes em proteína poderiam suprir, em parte, suas necessidades através do mecanismo de cecotrofagia (Herrera, 1985; Mendes et al., 1996) ou da quebra de proteína microbiana e absorção desta no cólon (González-Jiménez, 1995). Na natureza, a média de PB nos vegetais consumidos pelas capivaras é de cerca de $10 \%$ (Ojasti, 1973; González-Jiménez, 1977) . Embora o comportamento cecotrofágico não tenha sido observado nos animais do experimento (a frequência em animais alimentados com ração é bem menor do que em animais alimentados com volumoso, Mendes et al., 1996), é possível que os animais tenham se utilizado desse mecanismo, ingerindo as fezes ou cecotrofos em horários mais tranquilos e/ou durante à noite, quando não era possível observá-los.

Um terceiro aspecto a se considerar é o de que o excesso de proteína na ração poderia também estar acarretando prejuízos ao processo digestivo dos animais. Em coelhos, o excesso de proteína modifica o ambiente 
cecal de fermentação podendo, inclusive, gerar quadros de enterite. Essa alteração no meio de fermentação prejudica o bom aproveitamento e a digestibilidade dos nutrientes do bolo alimentar (Cheeke, 1987). O gasto energético com os processos de desaminação e degradação do excesso de proteína pelo organismo, com sobrecarga de trabalho para o figado e rins, e a utilização deste excesso protéico como fonte de energia, podem se equivaler aos ganhos obtidos com um maior nível protéico.

* Por fim, deve ser considerado o fato de que, por mais que cuidados tenham sido tomados, os animais do experimento estavam submetidos a uma carga de estresse bem superior aos demais animais do projeto, devido ao fato de estarem confinados em baias menores e sujeitos a manipulação frequente para pesagens e outros tratos. O estresse proporciona uma série de alterações no metabolismo de um animal, sendo que esta carga a qual os animais experimentais estavam submetidos pode ter influenciado em um menor aproveitamento do maior nível protéico (Allen \& Ullrey, 1992).

Na natureza, segundo Ojasti (1973), a capivara apresenta um GDP médio de $54 \mathrm{~g}$ nos dois primeiros anos de vida. Para animais jovens em cativeiro alimentados com cenouras, maçãs, alface e espinafre (na proporção de $19 \%$ da ingestão energética diária), ração para cães (71 \%) e lucerna (10\%), Vasey (1979) obteve ganhos diários de peso de 126,5 $\pm 10,6$ g. Segundo González-Jiménez (1995) animais alimentados com dietas com diferentes proporções de capim elefante e concentrado com $14 \%$ de PB (100:0, 65:35 e 53:47, respectivamente) obtiveram os respectivos GDP: 22,7, 93,0 e 92,4 g. Parra et al. (1978) encontrou que animais, entre os 4 e 10 meses de idade, alimentados com $70 \%$ de capim elefante e $30 \%$ de concentrado com $14 \%$ PB apresentavam GDP de 87,4 g/dia. Parra (1976) observou que capivaras pesando cerca de 
$11,0 \pm 2,6 \mathrm{~kg}$ de peso vivo (PV) obtinham um GDP de 85 a $90 \mathrm{~g}$, quando alimentadas com uma ração com $15 \%$ de PB e capim elefante (proporção de 70:30). Parra et al. (1978) obtiveram, alimentando capivaras de cerca de 14 a 21 kg de PV com capim elefante mais ração de 14\% de PB (50:50), um GDP de 127,2 g, e para animais de 22 a $27 \mathrm{~kg}$ de PV, alimentados com capim elefante mais ração contendo $18 \%$ de $\mathrm{PB}$ (50:50), um GDP de 89,3 g.

Lavorenti (1989) observou que animais de cativeiro do projeto da CIZBAS/ESALQ/USP, pesando entre 21 e $40 \mathrm{~kg}$ de PV, apresentaram uma média de 109,82 g de GDP sendo alimentados com uma dieta à base de $80 \%$ de alimento volumoso e $20 \%$ de alimento concentrado. Este mesmo autor relata que em capivaras em crescimento alimentadas com uma dieta contendo 12,15 e $18 \%$ de $\mathrm{PB}$, os ganhos de peso médio diário foram 106,62 , 107,32 e 111,54 g, respectivamente, não havendo entretanto diferenças significativas. Silva Neto (1989) relatou para animais, com peso médio inicial de $20 \mathrm{~kg}$, alimentados com capim elefante e ração contendo diferentes níveis de proteína $(13,5,17$ e 20,5 \% de PB) os seguintes GDP médios, respectivamente : 105,35 , 106,34 e 110,91 g/dia. Este mesmo autor observou ainda um GDP de 100,1 g/dia para animais com 22,25 kg de PV alimentados com uma ração com 16,25 \% de PB. Albuquerque (1993) obteve para capivaras entre 23 e $35 \mathrm{~kg}$ de PV ganhos de peso diário de 140, 134 e 162 g/dia para machos inteiros, machos castrados e fềmeas, respectivamente.

A Tabela 9 apresenta os valores de GDP em relação ao peso metabólico e ganho médio diário em percentual do peso vivo. Para essas variáveis as diferenças também não se mostraram significativas, mantendo uma tendência semelhante a do GDP. 
O valor médio de GDP em relação ao peso metabólico encontrado neste experimento foi de cerca de $10,05 \pm 1,04 \mathrm{~g} / \mathrm{kg}^{0,75}$ sendo inferior ao encontrado por Silva Neto (1989) para capivaras alimentadas com capim elefante e ração contendo diferentes níveis de proteína (13,5 , 17 e 20,5 \% de PB) que foi de $32,9 \mathrm{~g} / \mathrm{kg}^{0,75}$. O valor médio de GDP em percentual do peso vivo, $0,52 \pm 0,05 \% \mathrm{PV} / \mathrm{dia}$, foi superior ao encontrado por Silva Neto (1989), de 0,37 $\% \mathrm{PV} /$ dia.

Tabela 9 : Ganho médio diário de peso (GDP) em relação ao peso metabólico e em percentagem do peso vivo médio de capivaras em crescimento.

\begin{tabular}{lcc}
\hline & $\begin{array}{c}\mathbf{G D P}^{*} \\
\left(\mathbf{g} / \mathbf{k g}^{\mathbf{0} 75}\right)\end{array}$ & $\begin{array}{c}\mathbf{G D P}^{* *} \\
(\% \text { PV/dia })\end{array}$ \\
\hline Níveis de Proteína Bruta $^{1}$ & & \\
\hline PB1=13,5 \% & 9,71 & 0,54 \\
PB2=20,0\% & 10,39 & 0,50 \\
\hline Níveis de Energia Bruta $^{2}$ & & \\
\hline EB1=4.000 kcal/kg & 10,61 & 0,56 \\
EB2=4.500 kcal/kg & 9,48 & 0,53 \\
\hline Interações dos Níveis de PB X EB & & \\
\hline PB1 X EB1 (T1) & 10,89 & 0,56 \\
PB2 X EB1 (T2) & 10,34 & 0,53 \\
PB1 X EB2 (T3) & 8,53 & 0,45 \\
PB2 X EB2 (T4) & 10,44 & 0,54 \\
\hline
\end{tabular}

* -1- As médias dos níveis de PB, na coluna, não diferem, estatisticamente, pelo teste $\mathrm{F}$ (Prob $>\mathrm{F}=$ 0,55);2- As médias dos níveis de $\mathrm{EB}$, na coluna, não diferem, estatisticamente, pelo teste $\mathrm{F}$ $($ Prob $>\mathrm{F}=0,32) ; 3$ - As interações entre $\mathrm{PB} X \mathrm{XB}$ para a variável $\mathrm{GDP}^{0,75}$ são, estatisticamente, não significativas pelo teste $F$ (Prob $>F=0,28$ ).

** --1- As médias dos níveis de PB, na coluna, não diferem, estatisticamente, pelo teste $\mathrm{F}$ (Prob $>\mathrm{F}=$ 0,52);2- As médias dos níveis de EB, na coluna, não diferem, estatisticamente, pelo teste $\mathrm{F}$ (Prob $>\mathrm{F}=0,39) ; 3$ - As interações entre $\mathrm{PB} X$ EB para a variável \% de GDP em relação ao peso vivo médio são, estatisticamente, não significativas pelo teste $F(\operatorname{Prob}>F=0.28$ ).

A Figura 6 mostra os valores observados para crescimento em peso das capivaras submetidas às rações rações experimentais (T1,T2,T3 e T4), bem como a curva de crescimento das capivaras do projeto da CIZBAS/ESALQ (Andrade et al. , 1996) alimentadas com capim elefante (Pennisetum purpureum) 
e uma ração à base de rolão de milho e farelo de soja com cerca de em média $16 \%$ de $\mathrm{PB}$ e $3.200 \mathrm{kcal}$ de EB/kg. Foi observado que, até aproximadamente 206 dias de idade, a diferença entre os animais submetidos aos diferentes tratamentos é pequena. A partir desta idade pode-se verificar uma ligeira tendência de melhor desempenho dos animais alimentados com ração com menos energia e mais proteína, ou seja, a mesma tendência observada quando da análise de GDP. Contudo, também não existem diferenças significativas $(\mathrm{p}>0,05)$ entre os tratamentos para o peso vivo de capivaras com cerca de oito meses de idade (246 dias), como mostra a Tabela 10. Essa tendência se mostra mais pronunciada nos animais com cerca de 10 meses (282 dias). Os animais que foram mantidos até os 282 dias apresentaram os seguintes valores médios de peso vivo para cada tratamento $: \mathrm{T} 1=26,10 \mathrm{~kg} ; \mathrm{T} 2=35,30 \mathrm{~kg} ; \mathrm{T} 3=17,85 \mathrm{~kg} \mathrm{e} \mathrm{T} 4=20,50 \mathrm{~kg}$.

Tabela 10 : Efeito de níveis de PB e EB em rações sobre o peso vivo de capivaras em crescimento aos 246 dias de idade $(\mathrm{kg})$.

\begin{tabular}{|c|c|c|c|}
\hline \multirow[b]{2}{*}{ Níveis de PB } & \multicolumn{2}{|c|}{ Níveis de Energia Bruta } & \multirow{2}{*}{$\begin{array}{l}\text { Médias dos Níveis } \\
\text { de Proteína Bruta }^{1}\end{array}$} \\
\hline & $4.000 \mathrm{kcal} / \mathrm{kg}^{3 /}$ & $4.500 \mathrm{kcal} / \mathrm{kg}$ & \\
\hline $13,5 \%{ }^{4 /}$ & 18,20 & 17,59 & 17,89 \\
\hline $20,0 \%$ & 21,76 & 19,84 & 20,80 \\
\hline $\begin{array}{l}\text { Médias dos Níveis } \\
\text { de Energia Bruta }^{2}\end{array}$ & 19,98 & 18,71 & \\
\hline $\begin{array}{l}\mathrm{CV}=22,27 \% \\
\text { 1- As médias dos niveis } \mathrm{d} \\
\text { 2- As médias dos niveis } \mathrm{d} \\
\text { 3/ e } 4 / \text { - A interação entre } \\
\text { significativa pelo teste } \mathrm{F}\end{array}$ & $\begin{array}{l}\text { B não diferem, estat } \\
3 X \text { EB para a variáv } \\
\text { ob }>F=0,95 \text { ). }\end{array}$ & $\begin{array}{l}\text { mente, pelo teste } \\
\text { so vivo aos } 246 \mathrm{di}\end{array}$ & $\begin{array}{l}\text { lo teste } F(\text { Prob }>F=0,32) \\
\text { rob }>F=0,45) \\
\text { estatisticamente, não }\end{array}$ \\
\hline
\end{tabular}

Em comparação com os animais do plantel, as capivaras tratadas com as rações experimentais tiveram desempenho semelhante ou inferior, o que se deve, muito provavelmente, mais ao confinamento e ao intenso manejo 
(pesagens quinzenais) do que propriamente a alimentação. Todavia, pode-se verificar pela Figura 6 que, a partir dos oito meses, os animais que receberam dietas com menos energia e mais proteína ainda mantiveram um crescimento tendendo ao exponencial (potencial de atingirem maior peso à idade de abate) enquanto os animais do plantel começam a ter sua taxa de aceleração de crescimento reduzida. Aos dez meses de idade (meta de idade de abate considerada como ideal por González-Jiménez, 1995) os animais alimentados com dietas com 20,0\% de PB e $4.000 \mathrm{kcal} / \mathrm{kg}$ atingiram $35 \mathrm{~kg}$ de peso vivo (peso de abate considerado ótimo para o mercado) enquanto os animais do plantel atingiriam somente $26,03 \mathrm{~kg}$.

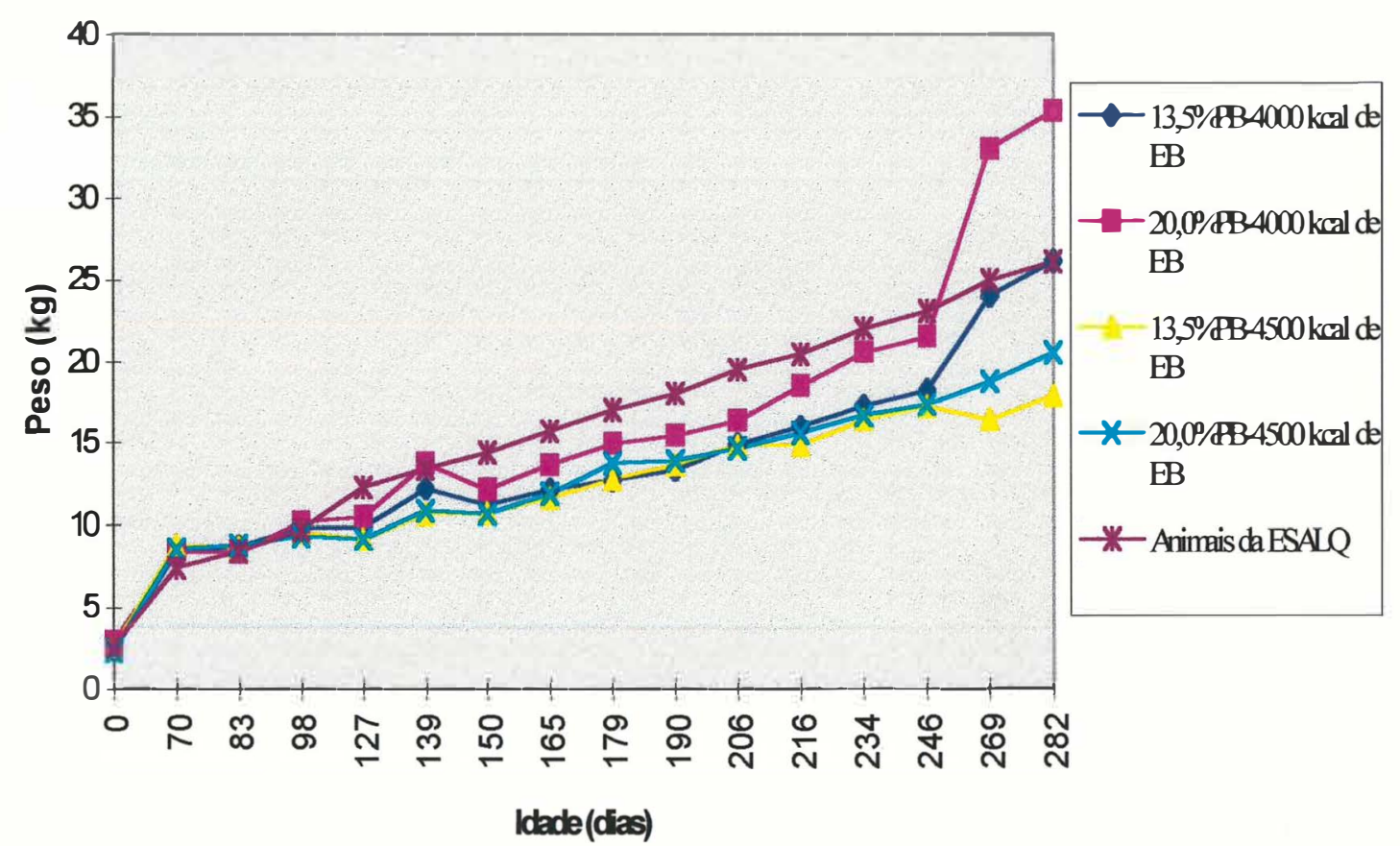

Obs: Curva de crescimento das capivaras da ESALQ adaptada de Andrade et al. (1996).

Figura 6 : Crescimento em peso de capivaras (H. h. hydrochaeris L. 1766) submetidas a rações com diferentes níveis de PB (13,5 e 20,0\%) e EB $(4.000$ e $4.500 \mathrm{kcal} / \mathrm{kg})$ e curva de crescimento das capivaras do projeto da CIZBAS/ESALQ/USP. 
Os resultados de GDP obtidos no presente experimento mostraram-se inferiores aos encontrados na literatura e semelhantes ao dos animais do projeto da CIZBAS que recebem uma dieta menos elaborada. Entretanto, deve ser considerado que esses animais não receberam capim, somente ração. $O$ capim entraria na alimentação não somente como fonte de fibra para uma fermentação cecal mais efetiva mas, também, como fonte de minerais e vitaminas. Como foi utilizado premix vitamínico e mineral na ração, possivelmente o menor desempenho não se deva a uma deficiência desses nutrientes, mas sim a uma modificação na eficiência digestiva das capivaras submetidas a uma dieta com baixo nível de fibra bruta (3,29\% em média), além de outros fatores que já foram mencionados anteriormente, entre eles: estresse pelo confinamento e manejo e variabilidade genética.

A alimentação exclusiva com ração contendo baixo nível de FB pode ter modificado o ambiente fermentativo cecal afetando o desempenho geral do animal. Contudo, deve-se considerar que a capivara, diferentemente do coelho, demonstrou, nesse experimento, ser tolerante a dietas com níveis reduzidos de fibra, sem apresentar grandes distúrbios fisiológicos. Hoje em dia, um dos grandes entraves nas grandes criações de coelhos é justamente o fornecimento de forragem de qualidade em quantidade suficiente (elevação dos custos com manutenção de capineira e mão-de-obra) ou a adição de altos níveis de fibra às rações - problemas com "pellets" quebradiços, maior desgaste das máquinas peletizadoras, etc. $\left(Z_{\text {insly }}{ }^{1}\right)$. No caso da criação de capivaras em regime intensivo, em regiões onde o clima não permita uma produção regular de forragem para o fornecimento aos animais, como no Sudeste do Brasil, a utilização, em determinados períodos, de uma dieta constituída somente de

\footnotetext{
${ }^{1}$ Dr. CIRO ZINSLY, professor de cunicultura do Depto. de Zootecnia da ESALQ/USP.1995. Informação pessoal.
} 
concentrado ou com maior proporção de matéria seca proveniente de concentrados que de volumosos, parece necessária e viável.

\subsubsection{Consumo :}

As Tabelas 11 e 12 apresentam os valores de consumo médio diário em gramas de matéria seca e em percentagem de peso vivo para os animais do experimento. Não foi observada nenhuma diferença significativa $(p>0,05)$ para essas variáveis entre os níveis de proteína e energia brutas utilizados, nem em suas interações. Os animais apresentaram um consumo médio diário de matéria seca de $301,58 \pm 16,40 \mathrm{~g} / \mathrm{dia}$, correspondendo a cerca de $2,78 \pm 0,15 \%$ do peso vivo.

Tabela 11 : Efeito de níveis de $\mathrm{PB}$ e EB em rações sobre o consumo médio diário em matéria seca para capivaras em crescimento (g/dia).

\begin{tabular}{|c|c|c|c|}
\hline \multirow[b]{2}{*}{ Níveis de PB } & \multicolumn{2}{|c|}{ Níveis de Energia Bruta } & \multirow{2}{*}{$\begin{array}{l}\text { Médias dos Níveis } \\
\text { de Proteína Bruta }\end{array}$} \\
\hline & $4.000 \mathrm{kcal} / \mathrm{kg}^{3 /}$ & $4.500 \mathrm{kcal} / \mathrm{kg}$ & \\
\hline $13,5 \%$ & 306,95 & 292,17 & 299,56 \\
\hline $20,0 \%$ & 322,05 & 285,14 & 303.59 \\
\hline $\begin{array}{l}\text { Médias dos Níveis } \\
\text { de Energia Bruta }\end{array}$ & 314,50 & 288,65 & \\
\hline $\begin{array}{l}\mathrm{CV}=13,85 \% \\
1-\text { As médias dos níveis d } \\
\text { 2- As médias dos níveis } \\
\text { interação entre } \mathrm{PB} X \mathrm{XB} \\
(\text { Prob }>\mathrm{F}=0,54) \text {. }\end{array}$ & $\begin{array}{l}\text { B, na coluna, não } \\
\text { EB não diferem, } \\
\text { ra a variável cons }\end{array}$ & $\begin{array}{l}\text { m, estatisticamente } \\
\text { icamente, pelo test } \\
\text {, estatisticamente, }\end{array}$ & $\begin{array}{l}\text { elo teste } F(\operatorname{Prob}>F=0,79) \\
(\text { Prob }>F=0,27) ; 3 / \text { e } 4 /- \\
\text { o significativa pelo teste }\end{array}$ \\
\hline
\end{tabular}


Tabela 12 : Efeito de níveis de $\mathrm{PB}$ e EB em rações sobre o consumo diário médio em $\%$ do peso vivo (PV) de capivaras em crescimento (\%).

\begin{tabular}{|c|c|c|c|}
\hline \multirow[b]{2}{*}{ Níveis de PB } & \multicolumn{2}{|c|}{ Níveis de Energia Bruta } & \multirow{2}{*}{$\begin{array}{l}\text { Médias dos Níveis } \\
\text { de Proteína Bruta }\end{array}$} \\
\hline & $4.000 \mathrm{kcal} / \mathrm{kg}^{3 /}$ & $4.500 \mathrm{kcal} / \mathrm{kg}$ & \\
\hline $13,5 \%{ }^{4 /}$ & 2,66 & 2,98 & 2,82 \\
\hline $20,0 \%$ & 2,81 & 2,68 & 2,74 \\
\hline $\begin{array}{l}\text { Médias dos Níveis } \\
\text { de Energia Bruta }^{2}\end{array}$ & 2,73 & 2,83 & \\
\hline $\begin{array}{l}\mathrm{CV}=10,72 \% \\
1 \text { - As médias dos niveis } \\
\text { 2- As médias dos niveis } \\
\text { interação entre } \mathrm{PB} X \mathrm{XB} \\
\text { teste } \mathrm{F} \text { (Prob > F }=0.12 \text { ) }\end{array}$ & ão diferem, & camente, pelo tes & $\begin{array}{l}\text { elo teste } \mathrm{F}(\mathrm{Prob}>\mathrm{F}=0,55) \\
(\text { Prob }>\mathrm{F}=0,49) ; 3 / \text { e } 4 / \text { - } \mathrm{A} \\
\text { nente, não significativa pelo }\end{array}$ \\
\hline
\end{tabular}

Observou-se que, embora não haja diferenças significativas entre os diferentes níveis de $\mathrm{PB}$ e EB para consumo médio diário de matéria seca e consumo médio diário em percentagem do peso vivo, pode-se considerar que houve uma tendência a um menor consumo de matéria seca nos tratamentos com maior nível energético (consumo regulado pela necessidade energética, Maynard \& Losli, 1966; Wohl \& Goodhart, 1964). A este fato pode ser relacionada a tendência a um menor GDP de animais submetidos aos tratamentos com maior nível energético, dado que, um menor consumo de ração levaria a reduzir a ingestão de outros nutrientes e, mesmo tendo suas necessidades energéticas atendidas, esses animais apresentariam deficiência em relação a esses outros nutrientes. Verificou-se ainda que, nos tratamentos com maior nível energético e com um maior nível de proteína os valores de GDP foram maiores do que aqueles em que havia um nível menor de proteína com maior nível de energia (73,69 e 59,04 g/dia, respectivamente), de onde se conclui que existiria também a necessidade de se elevar o nível dos demais nutrientes todas as vezes que se 
eleve o nível energético da ração para compensar a redução na ingestão de ração pelos animais.

Considerando-se que a ingestão diária média de energia bruta (EB) dos animais do experimento foi igual a 1.269,32 $\pm 38,86 \mathrm{kcal}$ é possível calcular que níveis de $\mathrm{PB}$ seriam necessários nas dietas com maior nível energético, para que os animais tivessem ingestão protéica equivalente a das capivaras que receberam uma dieta menos energética. $O$ consumo protéico ajustado à ingestão média diária de energia para as rações menos energéticas foram, respectivamente : $\mathrm{T} 1=46,07 \mathrm{~g} / \mathrm{dia}$ e $\mathrm{T} 2=64,86 \mathrm{~g} / \mathrm{dia}$. Para que os animais que receberam dietas com $4.500 \mathrm{kcal} \mathrm{de} \mathrm{EB} / \mathrm{kg}$, atingissem valores semelhantes de ingestão protéica, os níveis de PB deveriam ser elevados para : T3=16,16 \% e $\mathrm{T} 4=22,93 \%$.

Outra hipótese a ser considerada para essa tendência a um menor consumo de matéria seca nos tratamentos com maior nível energético é a de que essas rações estavam mais propensas à rancificação devido à maior conteúdo de extrato etéreo que possuíam. Como a capivara é um animal extremamente seletivo (Ojasti, 1973; González-Jiménez, 1995) quanto à palatabilidade de seus alimentos, é bem possível, que reduzisse o consumo quando ocorresse qualquer mudança no sabor da ração. Logo, quando da utilização de níveis mais elevados de energia e, conseqüentemente, de rações com maior teor de ex trato etéreo para capivaras, devem ser tomadas medidas necessárias para se evitar o mínimo de rancificação.

Os resultados obtidos para o consumo médio diário de matéria seca e em percentagem do peso vivo, 301,58 $\pm 16,40 \mathrm{~g} / \mathrm{dia}$ e $2,78 \pm 0,15 \%$ do $\mathrm{PV}$, foram inferiores aos encontrados na literatura . Ojasti (1973) determinou um consumo de $440 \mathrm{~g}$ de MS e 3,99 \% do PV para capivaras com 11,07 kg de peso 
vivo médio, e de $690 \mathrm{~g}$ de MS e de 1,72\% do PV para um animal de $40 \mathrm{~kg}$, sendo estes animais alimentados apenas com forragens. González-Jiménez \& Escobar (1975) observaram um consumo de $444 \pm 61 \mathrm{~g}$ de MS/dia para animais de 24,49 kg de PV médio, alimentados com dietas com diferentes proporções (100:0, 75:25, 50:50,25:75 e 0:100, respectivamente) de feno e de concentrado de 17,2\% de PB. Baldizán et al. (1982) registraram um consumo de 400 e 476 g de MS, para animais entre os 18-25 kg de PV, alimentados com feno de Cenchrus ciliares e com uma ração de $8,9 \%$ de PB com $15 \%$ de farinha de mandioca, respectivamente. Um consumo de 551 g de MS foi observado por Baldizán et al (1986) para animais alimentados com uma ração com 16,3\% de PB . GonzálezJiménez (1995) apresentou valores de 3,08\% do PV para capivaras que receberam uma dieta com $53 \%$ de capim elefante e $43 \%$ de concentrado ( $14 \%$ de PB).

Lavorenti (1989) relata um consumo de $4,1 \%$ do peso vivo para animais com 21 a $40 \mathrm{~kg}$ alimentados com $80 \%$ de capim e $20 \%$ de concentrado, no projeto da CIZBAS/ESALQ/USP. Silva Neto (1989) observou um consumo de $1.120,66$ e 1.075,01 g/dia para capivaras, acima dos $20 \mathrm{~kg}$ de PV, alimentadas com capim elefante ad libitum e ração contendo $13,5 \%$ e $20,5 \%$ de PB, respectivamente. Para animais com 22,25 kg de PV recebendo ração com 16,25\% de $\mathrm{PB}$ e $4.193 \mathrm{kcal}$ de EB/kg, esse mesmo autor encontrou um consumo de 588,5 g/dia. Bernardi (1993) observou para animais pesando 35,92 $\pm 5,61 \mathrm{~kg}$ de PV e confinados em gaiolas metabólicas e baias com $10 \mathrm{~m}^{2}$, consumos diários de $727,35 \pm 263,93$ e $715,34 \pm 181,24 \mathrm{~g}$ de MS/dia, respectivamente.

Em termos de consumo de MS/ kg de peso metabólico, Ojasti (1971) obteve um consumo de 46 e $124 \mathrm{~g}$ de $\mathrm{MS} / \mathrm{kg}^{0,75} / \mathrm{dia}$ para animais alimentados com Paspalum fasciculatum e Brachiaria mutica, respectivamente. González-Jiménez \& Escobar (1975) relatam um consumo diário por peso 
metabólico de $60,40 \mathrm{~g}$ de $\mathrm{MS} / \mathrm{kg}^{0,75}$ para capivaras alimentadas com feno e concentrado de $17,2 \%$ de PB em diferentes proporçôes. Parra et al. (1978) relata um consumo diário de 78,4 e $69,8 \mathrm{~g}$ de $\mathrm{MS} / \mathrm{kg}^{0.75}$ para animais com dietas de capim e ração com 14 e 18 \% de PB, respectivamente. Silva Neto (1989) obteve um consumo diário médio de $82,3 \mathrm{~g}$ de $\mathrm{MS} / \mathrm{kg}^{0,75}$ para capivaras alimentadas com capim elefante e ração (com 13,5, 17 e 20,5 \% de PB). Todos esses valores foram muito superiores a média encontrada no presente trabalho, 41,66 $\pm 1,5 \mathrm{~g}$ de $\mathrm{MS} / \mathrm{kg}^{0.75} / \mathrm{dia}$.

Os animais deste experimento apresentaram os seguintes consumos protéicos médios diários : $\mathrm{T} 1=44,01 \mathrm{~g}$ de $\mathrm{PB} / \mathrm{dia} ; \mathrm{T} 2=65,02 \mathrm{~g}$ de $\mathrm{PB} / \mathrm{dia} ; \mathrm{T} 3=40,41 \mathrm{~g}$ de PB/dia e T4 $=53,21 \mathrm{~g}$ de PB/dia. Analisando-se o consumo energético diário foram obtidos os seguintes valores : $\mathrm{T} 1=1.212,72$ $\mathrm{kcal}$ de $\mathrm{EB} ; \mathrm{T} 2=1.284,01 \mathrm{kcal}$ de EB; T3 $=1.301,06 \mathrm{kcal}$ de $\mathrm{EB}$ e $\mathrm{T} 4=1.279,49$ kcal de EB. Observa-se que o consumo energético diário é muito semelhante entre todos os tratamentos (embora, haja uma tendência a um maior consumo pelos animais que receberam dietas com maior nível de EB), o que demonstra que o consumo foi regulado pelas necessidades energéticas.

Vasey (1979) encontrou, para capivaras em crescimento, valores de consumo diário protéico (99 g de $\mathrm{PB} / \mathrm{dia}$ ) e energético (1780 kcal de EB/dia) superiores a média dos encontrados neste experimento, 50,66 g de PB/dia e $1.269,32 \mathrm{kcal}$ de EB/dia, respectivamente. Ojasti (1973) estimou, utilizando a equação proposta por Brody ${ }^{1}$ para o cálculo do metabolismo basal $(\mathrm{kcal} / \mathrm{dia}=$ 70,5. $\mathrm{M}^{0,75}$, em que $\mathrm{M}=$ peso vivo em $\mathrm{kg}$ ), que o gasto energético com o metabolismo basal para uma capivara de $40 \mathrm{~kg}$ é de $1.042 \mathrm{kcal} / \mathrm{dia}$. Esse mesmo

\footnotetext{
${ }^{1}$ BRODY, S. Bioenergetics and growth special references to the efficiency complex in domestic animals. Reinhold Publ. Corp., New York. 1945. 1023 p.
} 
autor verificou, através de um ensaio de digestibilidade de Paspalum fasciculatum uma necessidade diária de cerca de $1.320 \mathrm{kcal}$ de energia digestível para capivaras de $40 \mathrm{~kg}$ de PV.

Utilizando-se a mesma fórmula usada por Ojasti (1973) foram obtidos os seguintes valores de metabolismo basal para os animais deste estudo : $\mathrm{T} 1=501,71 \mathrm{kcal} / \mathrm{dia} ; \mathrm{T} 2=500,07 \mathrm{kcal} / \mathrm{dia} ; \mathrm{T} 3=456,72 \mathrm{kcal} / \mathrm{dia}$ e $\mathrm{T} 4=503,67$ $\mathrm{kcal} / \mathrm{dia}$. Os valores de necessidade calórica para manutenção, calculados pela equação kcal $=2 \times 70,5 \mathrm{X} \mathrm{M}^{0,75}$ (Andriguetto et al. , 1990), para os animais do experimento foram os seguintes: $\mathrm{T} 1=1.003,42 ; \mathrm{T} 2=1.000,14 ; \mathrm{T} 3=913,44 \mathrm{e}$ T4=1.007,34 kcal/dia. Esses valores são menores do que o consumo energético médio diário de $\mathrm{EB}$, indicando um saldo energético positivo médio de 288,23 $\mathrm{kcal} / \mathrm{dia}$.

Segundo Rostagno et al (1994) suínos na fase inicial de crescimento (entre os 15-30 kg de PV) necessitam de $220 \mathrm{~g}$ de PB/dia e 4.250 kcal de energia digestível/dia. Para cordeiros com peso médio de $30 \mathrm{~kg}$ as exigências de proteína e energia são em torno de $130 \mathrm{~g}$ de $\mathrm{PB} / \mathrm{dia}$ e de $3.560 \mathrm{kcal}$ de ED/dia (Campos, 1981).

\subsubsection{Conversão alimentar :}

A Tabela 13 apresenta os valores médios de conversão alimentar e GDP ajustado ao consumo por covariância. As dietas com maior nível de proteína bruta $(20 \%)$ apresentaram médias, estatísticamente $(\mathrm{p}<0,05)$, melhores (menor conversão alimentar e maior GDP ajustado) que as dietas com menor nível de PB. Não houve diferenças significativas $(p>0,05)$ para efeito dos níveis de energia bruta e nem entre as interações dos níveis de PB X EB. 
Tabela 13 : Efeito de níveis de PBe EB em rações sobre a conversão alimentar média e sobre o GDP médio ajustado ao consumo de capivaras em crescimento.

\begin{tabular}{|c|c|c|}
\hline & $\begin{array}{l}\text { Conversão } \\
\text { Alimentar* }\end{array}$ & $\begin{array}{l}\text { GDP ajustado ao } \\
\text { consumo (g/dia) }\end{array}$ \\
\hline \multicolumn{3}{|c|}{ Níveis de Proteína Bruta $^{1}$} \\
\hline PB1 $=13,5 \%$ & $6,18^{b}$ & $63,58^{b}$ \\
\hline PB2 $=20,0 \%$ & $5,08^{\mathrm{a}}$ & $76,51^{\mathrm{a}}$ \\
\hline \multicolumn{3}{|c|}{ Níveis de Energia Bruta ${ }^{2}$} \\
\hline $\mathrm{EB} 1=4.000 \mathrm{kcal} / \mathrm{kg}$ & 5,42 & 70,20 \\
\hline$E B 2=4.500 \mathrm{kcal} / \mathrm{kg}$ & 5,84 & 69,90 \\
\hline \multicolumn{3}{|c|}{ Interações dos Niveis de PB X EB ${ }^{3}$} \\
\hline PB1 X EB1 (T1) & 5,92 & 65,70 \\
\hline PB2 X EB1 (T2) & 4,93 & 74,70 \\
\hline PB1 X EB2 (T3) & 6,45 & 61,47 \\
\hline PB2 X EB2 (T4) & 5,23 & 78,32 \\
\hline
\end{tabular}

CV de conversão alimentar $=14,68 \% ;$ CV de GDP ajustado $=13,93 \%$

* -1- As médias dos niveis de PB, na coluna, seguidas de mesma letra não diferem, estatisticamente, pelo teste $\mathrm{F}$ (Prob $>\mathrm{F}=0,014) ; 2$ - As médias dos niveis de $\mathrm{EB}$, na coluna, não diferem, estatisticamente, pelo teste $F($ Prob $>F=0,52) ; 3$ - As interações entre $P B X$ EB para a variável conversão alimentar são, estatisticamente, não significativas pelo teste $\mathrm{F}$ (Prob $>\mathrm{F}=0,69$ ).

** - 1- As médias dos niveis de PB, na coluna, seguidas de mesma letra , não diferem, estatisticamente , pelo teste $\mathrm{F}$ (Prob $>\mathrm{F}=0,013$ ) ;2- As médias dos níveis de $\mathrm{EB}$, na coluna, não diferem, estatisticamente, pelo teste $F$ (Prob $>F=0,948) ; 3$ - As interações entre $P B X$ EB para a variável GDP ajustada ao consumo são, estatisticamente, não significativas pelo teste $F(\operatorname{Prob}>F=0,395)$.

A conversão alimentar média durante o período experimental foi de 5,63:1 variando de 1,83:1 até 18,52:1. Estes resultados foram melhores do que aqueles encontrados na literatura para capivaras que recebiam uma dieta contendo ração concentrada.

Parra et al. (1978) encontraram valores médios de conversão alimentar de 7,5:1 e 7,4:1 para animais alimentados com capim e ração contendo $18 \%$ e $14 \%$ de PB, na proporção de 56:44 e 43:57, respectivamente. Lavorenti (1989) determinou uma conversão alimentar média de 8,65:1 para animais que 
receberam $80 \%$ de capim e $20 \%$ de concentrado. Silva Neto (1989) obteve valores de conversão alimentar de 13,62:1, 13,90:1 e 13,09:1 para capivaras com peso vivo acima dos $20 \mathrm{~kg}$ e alimentadas com capim elefante e ração com 13,5, 17 e $20,0 \%$ de $\mathrm{PB}$, respectivamente. Esse mesmo autor observou que animais com 22,25 kg de PV alimentados apenas com ração de 16,25 \% de PB apresentavam uma conversão alimentar de 6,69:1. González-Jiménez (1995) relata valores de conversão alimentar média de $10: 1$ em animais alimentados com $53 \%$ de capim elefante e $47 \%$ de ração com $14 \%$ de $\mathrm{PB}$, sendo que para animais alimentados somente com capim a conversão foi de 22,7:1. Utilizando a curva de crescimento proposta por Andrade et al. (1996), foi estimado um valor de conversão alimentar de 9,1:1 para os animais com cerca de 17 a $32 \mathrm{~kg}$ de PV, em cativeiro no projeto da CIZBAS/ESALQ/USP, recebendo uma dieta básica de capim elefante e ração com cerca de $14 \%$ de PB e $3.200 \mathrm{kcal}$ de EB/kg, à uma taxa de arraçoamento em torno de $4 \%$ do peso vivo.

Segundo Cheeke (1987), em coelhos, maiores níveis energéticos na dieta melhoram a conversão alimentar, o que não aconteceu no presente estudo com capivaras. Isto, provavelmente, foi devido ao fato de não haverem sido ajustados os níveis dos outros nutrientes da dieta ao maior nivel energético, o que proporcionou um menor GDP e uma tendência a pior conversão nas dietas mais energéticas.

Comparando os valores de conversão protéica (consumo diário de proteína em gramas/GDP) dos animais do experimento, verifica-se que os animais do tratamento 1 , necessitaram de $0,66 \mathrm{~g}$ de $\mathrm{PB}$ para converter em $1 \mathrm{~g}$ de peso vivo, enquanto os animais de T2, T3 e T4 utilizaram, respectivamente, 0,81, 0,68 e $0,72 \mathrm{~g}$ de $\mathrm{PB}$. Estes valores mostram que, apesar dos animais que receberam o maior nível protéico (20\% de PB) apresentarem uma tendência a um maior GDP, foram os animais que consumiram menos proteína $(13,5 \%$ de $P B)$ que 
apresentaram por apresentar uma melhor conversão protéica. Essa melhor utilização da pouca proteína de uma dieta pelas capivaras pode, muito provavelmente, estar relacionada, como mencionado anteriormente, a eficientes adaptações fisiológicas e comportamentais para manter o equilíbrio do balanço de nitrogênio.

Outro aspecto, que pode ser relacionado a essa pior conversão protéica dos animais que receberam maiores níveis de $\mathrm{PB}$, está relacionado ao fato de que, ao ingerirem maior quantidade de proteína, esses animais podem estar atendendo a suas necessidades em determinados aminoácidos, mas podem também ter ingerido certos aminoácidos em excesso. Esse excesso de aminoácidos é degradado pelo organismo aravés do processo de desaminação, sendo seus esqueletos carbônicos utilizados para a síntese de outros aminoácidos ou convertidos, por exemplo, na gluconeogênese em substâncias energéticas. Ou seja, altos níveis protéicos podem levar a ingestão de um excesso de aminoácidos, que levam a uma pior conversão protéica devido aos gasto de energia para degradação dos aminoácidos em excesso e pelo fato do animal aproveitar proteína como fonte de energia (Morrison, 1948; Wohl \& Goodhart, 1964).

Todavia, quando se analisaram os valores médios de conversão energética, foi observado que os animais que receberam mais proteína tenderam a utilizar mais eficientemente a energia para converter em peso vivo $(\mathrm{T} 2=16,58$ kcal e T4 $=16,15 \mathrm{kcal}$ para ganhar um grama de peso vivo), enquanto, os animais que receberam menos proteína necessitaram de mais energia para converter em um grama de peso vivo $(\mathrm{Tl}=18,96 \mathrm{kcal}$ e $\mathrm{T} 3=20,32 \mathrm{kcal})$. Como o consumo energético é semelhante, a menor eficiência em termos da conversão da energia do alimento em peso vivo só pode ser explicada, justamente, pela menor ingestão protéica, que estaria portanto abaixo das necessidades do animal. Além disso, deve-se considerar, também, o gasto energético que a capivara submetida a uma 
dieta deficiente em proteína deve ter ao se utilizar de seus mecanismos para manter o balanço de nitrogênio (cecotrofagia, autólise da proteína microbiana cecal, etc.).

Nos animais que receberam $20 \%$ de PB, o excedente protéico foi aproveitado como fonte de energia e, como não chegou a níveis problemáticos com extrema sobrecarga para o figado e os rins, acabou por beneficiar o animal lhe proporcionando uma energia extra, possivelmente, utilizada na produção de músculo e/ou gordura, levando com isso a um incremento a mais no ganho de peso.

Vasey (1979) obteve valores de conversão protéica entre 1,1 e 0,5 gramas de proteína para cada grama de peso vivo e valores de conversão energética de 18 e $10 \mathrm{kcal}$, respectivamente, por grama de ganho de peso para animais em crescimento alimentados com ração para cães, cenouras, alfaces, maçãs e lucerna.

Segundo González-Jiménez (1995) animais mais novos apresentam maior GDP e melhor conversão alimentar do que animais mais velhos. Animais de $15-20 \mathrm{~kg}$ que receberam capim elefante e ração concentrada com $18 \%$ de PB , na proporção de 60:40, apresentaram uma conversão alimentar igual a 5,9:1, sendo que animais de $20-25 \mathrm{~kg}$ que receberam a mesma dieta apresentaram uma conversão de $8,88: 1$. A mesma tendência pode ser observada ao se utilizar a curva de crescimento para capivaras em cativeiro proposta por Andrade et al. (1996). Capivaras de 17,16 a 32,28 kg de PV apresentaram uma conversão alimentar de 9,1:1. No presente estudo não foi observada essa tendência, não sendo significativa a regressão entre a conversão alimentar e a idade dos animais para os diferentes tratamentos, sendo obtidos os seguintes valores de $\mathrm{r}^{2}: \mathrm{T} 1=0,20 ; \mathrm{T} 2=0,26 ; \mathrm{T} 3=0,10$ e $\mathrm{T} 4=0,05$. 
Os animais deste experimento apresentaram, de modo geral, menor GDP e menor consumo diário do que os encontrados para capivaras na literatura. Contudo, apresentaram valores de conversão alimentar melhores ou semelhantes aos da literatura, indicando que seu desempenho foi, possivelmente, afetado pela menor ingestão de MS, sendo que esta por sua vez deve ter sido influenciada pelo estresse, devido ao confinamento e ao excesso de manejo, e pelo apetite do animal que, sendo herbívoro, prefere muito mais consumir forragens verdes do que rações concentradas.

\subsubsection{Mortalidade}

Durante o experimento, alguns animais apresentaram problemas de ordem clínica, que os levaram à morte ou à retirada do experimento. Esses problemas foram os seguintes: quebra de dentes ; fratura de membros ; anorexia e diarréia causada por virose. Em virtude dos problemas com virose, um bloco (repetição) do experimento (inicialmente planejado para seis blocos) foi descartado, entretanto seus dados foram incluídos para a análise da taxa de incidência de doenças e de mortalidade.

A taxa de mortalidade dos animais do experimento foi de $20 \%$, valor maior que a taxa média encontrada por Lavorenti et al. (1989) que foi de $15,05 \%$ da desmama até um ano de idade e, menor que a taxa obtida por Nogueira Filho et al. (1996) que foi de $31,83 \%$ para os animais do projeto da CIZBAS e que a taxa encontrada por Ojasti (1973) para os animais na natureza ( $35 \%$ até os 7 meses de idade).

Todos os animais foram vermifugados e pulverizados contra parasitas, antes e no meio do período experimental. As baias foram rigorosamente 
higienizadas. Pelo monitoramento das fezes dos animais experimentais, foi verificado que os mesmos não apresentaram problemas de endoparasitose.

A primeira hipótese, para o problema de animais quebrarem os dentes ou fraturarem o membro anterior (em todos os casos no osso rádio), foi de que haveria uma deficiência nutricional em termos de cálcio $(\mathrm{Ca})$ e fósforo $(\mathrm{P})$ que poderia estar levando os animais a um processo de descalcificação óssea. Foi feita a análise de $\mathrm{Ca}$ e $\mathrm{P}$ nos ossos da costela dos animais experimentais abatidos, sendo verificado que não havia diferenças significativas entre o teor desses minerais nos ossos dos animais experimentais e de outros animais do projeto que foram abatidos. Os níveis de Ca e P, na MS, encontrados nos ossos dos animais do experimento e outros animais do projeto foram respectivamente: $\mathrm{T} 1=14,17 \mathrm{e}$ $10,90 \% ; \mathrm{T} 2=14,55$ e $11,19 \% ; \mathrm{T} 3=14,09$ e $10,84 \% ; \mathrm{T} 4=14,55$ e $11,19 \%$; animais da $\mathrm{CIZBAS}=14,01$ e $10,78 \%$.

A análise de densidade óssea, através da radiografia dos membros anteriores de 10 animais do experimento, também não revelou nenhuma modificação significativa da estrutura dos ossos. Por essas evidências e pelo fato da proporção de Ca:P utilizada nas rações experimentais (1,3:1) ser a mesma que vem sendo utilizada, sem problemas, em outras rações do projeto da CIZBAS/ESALQ/USP, concluiu-se que, possivelmente, a causa das fraturas dos membros anteriores e a quebra dos dentes não era por deficiência de Ca e P.

Os três animais que fraturaram o rádio morreram. Dois destes animais foram enviados para necrópsia nas Faculdades de Veterinária da UNESP (Universidade Estadual de São Paulo), um para o campus de Jaboticabal e outro para o de Botucatu. O laudo da UNESP-Botucatu não foi conclusivo. O laudo da UNESP-Jaboticabal informou que o animal necropsiado apresentava um processo de osteocondrose generalizado, provavelmente, por crescimento esquelético 
excessivamente rápido, o que talvez estivesse ligado a um excesso de calorias. Houve uma nítida retenção de núcleo cartilaginoso de ossificação junto a metáfise femural. $\mathrm{O}$ fato da musculatura estar fixa na região da epífise levou ao surgimento de pontos de tensão com o crescimento dos ossos e o não acompanhamento da musculatura, o que tornou os ossos longos dos membros mais susceptíveis a fraturas.

É relatado na literatura (Lewis, 1979; Rezende et al., 1996) que potros jovens que recebem suplementação alimentar com concentrados tornam-se mais propensos a distúrbios no metabolismo ósseo que podem trazer como consequência a epifisite. Lewis (1979) menciona que a causa da epifisite é o rápido crescimento que os potros submetidos a suplementação apresentam. $\mathrm{O}$ aumento da taxa de crescimento ocasionado pela ingestão de grandes quantidades de proteína e energia não é acompanhado por uma deposição satisfatória de cálcio e fósforo nos ossos. Thompson et al. (1987) verificaram que existe uma relação entre o ganho de peso acima da média e a ocorrência de epifisite. Rezende et al. (1996) observou que potros alimentados, do nascimento aos 12 meses, com concentrados acrescido de mistura mineral tiveram uma menor incidência de epifisite.

No presente estudo, os animais mais pesados, realmente apresentavam uma estrutura corporal mais alongada, sendo animais bem desenvolvidos em tamanho sem apresentarem, entretanto, grande massa muscular. Isto ficou confirmado, posteriormente, quando da dissecção física da carcaça dos animais (maior proporção óssea nos animais do experimento do que em outros animais abatidos no projeto).

Contudo, pelo que foi observado durante o experimento, verificou-se que, provavelmente, a causa principal da fratura de dentes e ossos 
nas capivaras deveu-se bem mais ao manejo a que estes animais estavam submetidos, com capturas quinzenais para pesagens, em baias com espaço restrito. Por mais que fossem tomados todos cuidados necessários, durante a captura, muitos animais se chocavam contra as telas ou muros das baias, sendo que, os casos de fratura do rádio se manifestaram sempre após um dia de pesagem e, na necrópsia dos mesmos, esses apresentavam pontos de miopatia de captura nos membros.

Animais que entraram no experimento mais velhos (150 dias de idade) não apresentaram nenhum tipo de problema. Todos os casos de fratura de membro e quase todos os casos da virose (com exceção de um animal) ocorreram com animais menores e mais leves. Verificou-se que esses animais, mesmo que não fossem acometidos por qualquer distúrbio, apresentavam um baixo desempenho, com grandes oscilações entre perdas e ganhos de peso. Foi observado que esses animais mais leves eram, em sua maioria, originalmente problemáticos, sendo os menores de sua ninhada ou pertencentes a ninhadas de filhotes pequenos. Este fato pode tanto estar ligado a variabilidade genética da espécie quanto a organização hierárquica das capivaras, que se manifesta já enquanto filhotes.

A quebra de dentes pode ter gerado diversos prejuízos, não só pela redução do consumo e, consequentemente, maior debilidade do animal, bem como pela formação de abcessos que acabaram por se constituir em porta de entrada para outras infeç̧ões. Esse problema apareceu somente nos animais que entraram no experimento com menor idade (70 dias).

Esses animais mais novos, provavelmente, sofreram uma carga de estresse muito maior ao serem colocados no experimento. Além da desmama precoce, por volta dos 60 dias (na natureza, ocorre entre 90 - 120 dias), e do 
afastamento do grupo, esses animais apresentavam uma estrutura óssea bem mais frágil, e portanto, mais sujeita a traumatismos durante as capturas para pesagens.

Todos esses fatos interligados provocaram um quadro geral de depressão na imunidade desses animais, o que, provavelmente, culminou no surto virótico que acometeu um dos blocos do experimento.

Os sintomas que os animais apresentaram foram anorexia, ataxia, diarréias intermitentes e profusas, emagrecimento rápido e desidratação, e alteração na forma de caminhar com enrijecimento dos dedos (andavam na "ponta dos dedos"). Foram coletadas fezes e tecido intestinal dos animais que vieram a óbito. Esse material foi enviado para análise no Instituto Biológico de São Paulo. Com o resultado dessas análises foi constatada a presença de Coronavírus, similares aos de cepa suína, nas fezes e nos tecidos dos animais (Catroxo et al., 1995).

O Coronavirus é um vírus intestinal oportunista que provoca um quadro de sintomas muito similar ao descrito para os animais doentes do experimento, sendo que suas diferentes cepas provocam mortalidade em leitões, potros e até em aves.

Durante o surto havia animais de mesma idade mantidos junto às suas mães dentro dos grupos de reprodução e, portanto, com aleitamento completo. Esses animais se desenvolveram normalmente e não manifestaram o menor sinal da doença, o que leva a crer que teria sido a soma das condições anteriormente citadas, como estresse, problemas de manejo, abcessos pela quebra de dentes e até um ambiente cecal mais propício, devido à modificação do meio fermentativo pela ingestão de uma dieta concentrada com menos fibra, que levou a uma menor resistência e ao ataque do vírus. Animais do experimento que 
apresentavam maior peso não apresentaram a doença, indicando uma maior resistência.

Dos animais acometidos com a doença, $60 \%$ morreram e $40 \%$ se recuperaram. Destes $40 \%$, apenas um chegou até a fase mais aguda da doença. Nenhum tratamento alopático, tais como aplicação de antibióticos, soro e complexos vitamínicos, nem a mudança de alimentação ofereceram resultados. Os animais que sobreviveram à doença foram aqueles realojados em piquetes, permanecendo aí sem qualquer tipo de manejo. Esses animais. mantidos longe do confinamento e do estresse experimental, se recuperaram lentamente, até não apresentarem mais sintomas da doença, atingindo inclusive, posteriormente, bom desenvolvimento.

Não houve diferenças, entre os tratamentos, no número de animais acometidos de doenças ou outros distúrbios (doentes $=14$; sadios $=35$ ) e no número de animais que morreram - mortalidade: sobreviventes $=39$; mortos $=10$ - pelo teste qui-quadrado de Mantel-Haenszel, probabilidade igual a 0,22 e 0,18, respectivamente.

As análises de variância das taxas de incidência de doenças e de mortalidade também não apresentaram diferenças significativas entre os tratamentos como mostra a Tabela 14.

Pode-se verificar que houve uma tendência de os animais que receberam uma dieta com maior nível de energia apresentaram uma menor incidência de doença $(16,67 \%)$ e uma menor mortalidade (11.85\%). Animais sob estresse passam por modificações metabólicas para se ajustarem a novas situações, essas modificações demandam um gasto maior de energia, que deve ser reposto para que o animal não entre em colapso. 
Tabela 14: Efeito de níveis de $\mathrm{PB}$ e EB em rações de capivaras em crescimento sobre a taxa de incidência de doenças e a taxa de mortalidade dos animais.

\section{Taxa de Incidência de Doenças (\%)*}

Taxa de Mortalidade

$(\%)^{* *}$

\begin{tabular}{lcc}
\hline Níveis de Proteína Bruta $^{1}$ & & \\
\hline PB1=13,5 \% & 29,17 & 20,8 \\
PB2=20,0 \% & 25,0 & 20,2 \\
\hline Níveis de Energia Bruta $^{2}$ & & \\
\hline EB1=4.000 kcal/kg & 37,5 & 29,15 \\
EB2=4.500 kcal/kg & 16,67 & 11,85 \\
\hline Interações dos Níveis de PB X & & \\
EB $^{3}$ & 41,67 & 33,3 \\
\hline PB1 X EB1 (T1) & 33,33 & 25,0 \\
PB2 X EB1 (T2) & 16,67 & 8,3 \\
PB1 X EB2 (T3) & 16,67 & 15,4 \\
PB2 X EB2 (T4)
\end{tabular}

CV da taxa de incidência de doenças $=78,65 \%$; CV da taxa de mortalidade $=121,21 \%$

* -1 - As médias dos níveis de PB, na coluna, não diferem, estatisticamente, pelo teste $F$ (Prob $>F=$ 0,55);2- As médias dos níveis de $\mathrm{EB}$, na coluna, não diferem, estatisticamente, pelo teste $\mathrm{F}$ $($ Prob $>F=0,32) ; 3$ - As interações entre $P B X$ EB para a variável taxa de incidência de enfermidades são , estatisticamente, não significativas pelo teste $F$ (Prob $>F=0,28$ ).

** --1- As médias dos níveis de PB, na coluna, não diferem, estatisticamente, pelo teste $F$ (Prob $>F=$ 0,52);2- As médias dos niveis de $\mathrm{EB}$, na coluna, não diferem, estatisticamente, pelo teste $\mathrm{F}$ (Prob $>\mathrm{F}=0,39) ; 3$ - As interações entre $\mathrm{PB} X \mathrm{XB}$ para a variável taxa de mortalidade são, estatisticamente, não significativas pelo teste $F$ (Prob $>F=0,28)$.

Segundo Gedek et al. (1993) maiores níveis de energia metabolizável (EM) nas rações melhoram a saúde e a eficiência alimentar dos animais. Latshaw (1991) observou que variações na ingestão energética têm resultado em efeito sobre a imunocompetência.

Praharaj et al. (1995) estudaram os efeitos de níveis de proteína e energia em rações sobre o crescimento, a imunocompetência e a resistência a doenças de poedeiras comerciais leves (PCL), frangos de linhagem comercial 
(FLC) e frangos de linhagem precoce (FLP). Estes autores verificaram que poedeiras (PCL) alimentadas com uma ração com 17\% a mais de EM e $20 \%$ a mais de proteína do que uma dieta basal de controle, apresentavam maiores taxas de imuno-resposta quando inoculadas com vírus da doença "marble spleen". Jose et al. (1973) observaram que camundongos desmamados submetidos a dietas com menos proteína e energia têm menor resposta de imunidade em relação aos animais que receberam uma dieta controle ou apenas com menor nível protéico, mesmo após voltarem a consumir a dieta controle por 12 semanas.

Blood et al. (1979) afirmaram que nos animais os efeitos de uma deficiência energética são mais graves do que os de uma deficiência protéica, pelo menos na sua fase inicial. Em animais jovens um suprimento insuficiente de energia resulta em atraso no crescimento e no aparecimento da puberdade, além de debilidade e maior taxa de mortalidade.

De acordo com Maynard \& Loosli (1966) não existe uma tendência nítida de redução da incidência de doenças e da taxa de mortalidade para animais que receberam maior nível protéico. A reserva proteínica, formada a partir de um excedente protéico, é importante fonte da qual dependem as proteínas do plasma e a hemoglobina. Uma dessas proteínas é a soro-globulina, a partir da qual os anticorpos são produzidos, entretanto a subnutrição protéica está mais ligada a ocorrência de doenças infecciosas. Níveis adequados de proteína são importantes para aumentar a resistência a infecções. Contudo, Wohl \& Goodhart (1964) mencionaram que a ingestão excessiva de proteína além de reduzir a eficiência da utilização protéica, leva a um desbalanço de fluidos, pelo aumento das exigências em água e dos produtos finais do metabolismo protéico na corrente sanguínea e isto pode gerar uma sobrecarga nas funções do figado e rins dos animais, que poderia agravar o estado geral de animais doentes ou estressados. 


\subsubsection{Parâmetros de carcaça :}

Na Tabela 15 são apresentados os valores da análise quantitativa da carcaça dos animais experimentais abatidos. As médias das variáveis foram ajustadas , quando possível, à covariável peso do corpo vazio (Albuquerque, 1993), sendo que a covariância só foi significativa $(\mathrm{p}<0,05)$ para as variáveis rendimento em carne e teor de gordura corporal. Não houve diferenças estatísticas significativas $(\mathrm{p}>0,05)$ para as seguintes variáveis : peso vivo do animal em jejum

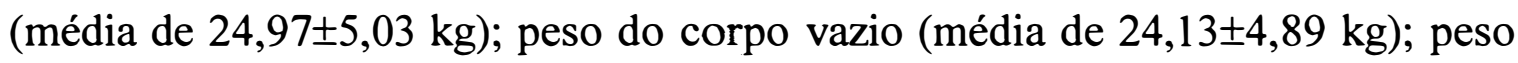
da carcaça quente $(15,44 \pm 3,43 \mathrm{~kg})$; perdas por resfriamento $(5,36 \pm 4,08 \%$ ); rendimento de carcaça em relação ao peso do animal em jejum (61,64 $\pm 2,79 \%$ ); rendimento de carcaça em relação ao peso do corpo vazio $(63,57 \pm 2,69 \%)$ e peso do couro $(2,08 \pm 0,33 \mathrm{~kg})$.

Houve diferença entre os tratamentos $(p<0,05)$, para o rendimento de carne e para o teor de gordura corporal (gordura intramuscular e subcutânea) em relação a meia carcaça direita resfriada. Pelo teste t, animais que receberam uma ração com menos proteína apresentaram um maior rendimento em carne $(70,45 \%)$ e tiveram uma tendência a um menor teor de gordura $(17,02 \%)$. Animais alimentados com dietas com maior nível energético apresentaram uma tendência a ter um maior teor de gordura. Animais que receberam dietas com menos proteína tenderam a acumular mais gordura subcutânea e menos gordura intramuscular (703,5 e 820,0 g, respectivamente) do que animais que receberam mais proteína (432,5 e 1056,2 g). Animais que receberam uma dieta menos energética tiveram menor acúmulo de gordura subcutânea e maior acúmulo de gordura intramuscular $(523,7$ e $987,5 \mathrm{~g}$, respectivamente) do que os que receberam mais energia $(612,5$ e $888,7 \mathrm{~g})$. 
Tabela 15: Análise quantitativa de carcaça de capivaras (H. h. hydrochaeris L., 1766) alimentadas com rações com diferentes níveis de PB (\%) e EB $(\mathrm{kcal} / \mathrm{kg})$ e abatidas aos 10 meses de idade.

\begin{tabular}{|c|c|c|c|c|c|}
\hline & $\begin{array}{c}\text { Carcaça } \\
\text { Quente } \\
(\mathbf{k g})^{\#}\end{array}$ & $\begin{array}{c}\text { Rendimento } \\
\text { de Carcaça } \\
(\%)\end{array}$ & $\begin{array}{c}\text { Rendimento } \\
\text { em Carne } \\
(\%)^{\#-1}\end{array}$ & $\begin{array}{c}\text { Teor de } \\
\text { Gordura } \\
(\%)^{\#-1}\end{array}$ & $\begin{array}{c}\text { Peso do } \\
\text { Couro } \\
\text { (kg) }\end{array}$ \\
\hline \multicolumn{6}{|l|}{$\begin{array}{l}\text { Médias dos E- } \\
\text { feitos Principais }\end{array}$} \\
\hline $\mathrm{PB} 1=13,5 \%$ & 15,09 & 62,58 & $70,45^{\mathrm{a}}$ & 17,02 & 2,20 \\
\hline PB2=20,0\% & 15,76 & 65,55 & $65,65^{b}$ & 17,88 & 2,04 \\
\hline $\mathrm{EB} 1=4.000 \mathrm{kcal}$ & 14,86 & 61,87 & 67,32 & 15,91 & 2,25 \\
\hline $\mathrm{EB} 2=4.500 \mathrm{kcal}$ & 15,98 & 65,33 & 68,78 & 18,99 & 2,04 \\
\hline \multicolumn{6}{|l|}{$\begin{array}{l}\text { Médias das } \\
\text { Interações }\end{array}$} \\
\hline PB1 X EB1(T1) & 14,43 & 61,98 & $73,06^{\mathrm{a}}$ & $10,38^{5-}$ & 2,50 \\
\hline PB2 X EB1(T2) & 15,30 & 61,66 & $61,58^{b}$ & $21,45^{a b}$ & 1,75 \\
\hline PB1 X EB2(T3) & 15,76 & 63,17 & $67,84^{a b}$ & $23,66^{\mathrm{a}}$ & 1,89 \\
\hline PB2 X EB2(T4) & 16,21 & 67,49 & $69,72^{\mathrm{a}}$ & $14,32^{\mathrm{ab}}$ & 2,19 \\
\hline
\end{tabular}

\# - Médias ajustadas pela covariável Peso do Corpo Vazio.

1 - Médias seguidas de letras diferentes, nas colunas de cada grupo (efeitos principais e interações), diferem estatísticamente, ao nível de $5 \%$, pelo teste $\mathrm{t}$.

As interações entre PB X EB foram significativas $(p<0,05)$ para $o$ rendimento em carne e teor de gordura. Os animais que receberam uma dieta com menos proteína e menos energia (T1) apresentaram maior rendimento em carne e menor teor de gordura confirmando a tendência observada quando da análise da conversão e eficiência protéica. Esses animais aproveitaram melhor a pouca proteína que receberam convertendo-a em came e não a utilizando como fonte de energia (conversão em gordura). Animais que receberam mais proteína em um baixo nível energético (T2) apresentaram o menor rendimento em came e um alto teor de gordura. Esses animais foram os que apresentaram os maiores GDP durante o experimento, contudo, essa análise de carcaça confirma um excesso de proteína que foi utilizado como fonte de energia, ou seja, os animais de T2 
tiveram um maior peso vivo devido ao acúmulo de gordura e não ao aumento da massa muscular.

Animais que receberam maior nível de energia mas com um menor nível protéico (T3) tiveram o maior teor de gordura e um rendimento em came superior a T2. Neste caso, como os animais dispunham de um maior nível de energia mas possuíam deficiência em proteína, ficaram impossibilitados de usar o excedente energético para a produção de carne, convertendo-o em gordura. Com um maior nível protéico e um maior nível de energia (T4), os animais aproveitaram mais eficientemente o excedente de energia convertendo a maior quantidade de proteína ingerida em carne, apresentando um menor teor de gordura do que T3.

Ojasti (1973) encontrou para capivaras de vida livre abatidas na

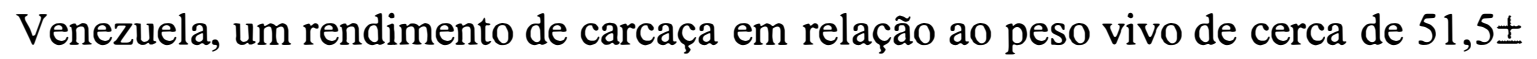
$0,33 \%$. Esse mesmo autor citando Ledger ${ }^{1}$ afirma que esse rendimento coincide com o que foi registrado para 19 espécies de mamíferos domésticos e silvestres (entre 41,9 e $65,0 \%)$ sendo ligeiramente abaixo da média geral $(55,7 \%)$. Godoy et al (1976) também relataram um rendimento em torno de $51,51 \%$ em relação ao peso vivo. Assaf et al. (1976) encontraram um rendimento médio de $54,25 \%$ em relação ao peso vivo. Albuquerque (1993) obteve os seguintes rendimentos de carcaça quente (\%) em relação ao peso em jejum e ao peso do corpo vazio para animais de cerca de $35 \mathrm{~kg}$ de $\mathrm{PV}$ : machos inteiros, 50,70 e 54,30 \%; machos castrados , 49,80 e 54,90 \%; e fêmeas, 50,40 e 54,90\%. Esses valores são inferiores aos encontrados no presente experimento , 61,64 \% em relação ao peso vivo em jejum e $63,57 \%$ em relação ao peso do corpo vazio, que se aproximam do valor preconizado por Lavorenti (1989) como meta a ser alcançada.

\footnotetext{
${ }^{1}$ LEDGER,H.P. Wildlife and Food Production. World Rev. Anim. Prod. 1967. 3(11): 13-37.
} 
Assaf et al. (1976) e Godoy \& Gómez (1976) obtiveram, respectivamente, rendimentos em carne de $87,12 \%$ e $84,88 \%$ em animais com PV entre 30 e $50 \mathrm{~kg}$. Albuquerque (1993) encontrou um rendimento em carne de $75,26 \pm 0,58 \%$ para animais pesando aproximadamente $35 \mathrm{~kg}$ de PV. Esse rendimento em carne foi maior do que o encontrado neste estudo, provavelmente, pelo fato dos animais do experimento apresentarem maiores proporções de gordura (devido a uma dieta com maiores níveis energéticos e protéicos) e ossos em relação à massa muscular. Albuquerque (1993) obteve um teor médio de

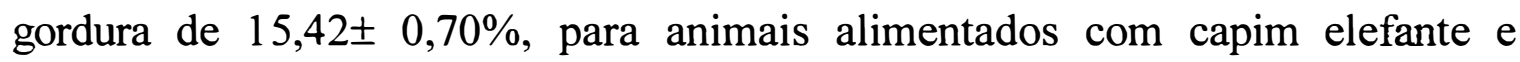
concentrado com $13,3 \%$ de $\mathrm{PB}$ e $3092 \mathrm{kcal}$ de EB/kg. Os animais analisados por Albuquerque (1993) foram alimentados com menores níveis energéticos e protéicos do que os animais deste experimento e apresentaram a mesma tendência destes, ou seja, acumularem mais gordura subcutânea do que intramuscular.

O percentual médio do peso do couro em relação ao peso vivo para os animais deste estudo, $8,63 \pm 1,38 \%$, foi similar ao encontrado por Albuquerque (1993) que foi de 9,5 $\pm 0,58 \%$.

$\mathrm{Na}$ Tabela 16 são apresentados os valores de rendimento médio dos principais cortes comerciais de capivara. $\mathrm{O}$ rendimento dos cortes foi medido em relação ao peso do corpo vazio $(\% \mathrm{CV})$ e em relação ao peso da meia carcaça esquerda resfriada (\%MCE), de onde foram retirados os cortes. Não houve diferenças estatísticas significativas entre os tratamentos, para o rendimento dos cortes em relação ao peso da meia carcaça esquerda (\%MCE). Para o rendimento dos cortes em relação ao peso do corpo vazio $(\% \mathrm{CV})$ houve interações significativas $(\mathrm{p}<0,05)$ dos níveis de $\mathrm{PB} X \mathrm{XB}$, para o rendimento de paleta e de costela. 
Tabela 16: Rendimento dos cortes comerciais de capivaras $(H . h$ hydrochaeris L., 1766) alimentadas com rações com diferentes níveis de proteína bruta $(\mathrm{P} 1=13,5 \%$ e $\mathrm{P} 2=20,0 \%)$ e energia bruta $(\mathrm{E} 1=4.000 \mathrm{kcal} / \mathrm{kg}$ e $\mathrm{E} 2=4.500 \mathrm{kcal} / \mathrm{kg})$.

\begin{tabular}{lcccccccc}
\hline & \multicolumn{3}{c}{$\begin{array}{c}\text { Médias dos Efeitos } \\
\text { Principais }\end{array}$} & \multicolumn{5}{c}{ Médias das Interações } \\
\cline { 2 - 9 } & P1 & P2 & E1 & E2 & P1xE1 & P2xE1 & P1xE2 & P2xE2 \\
\hline Pernil & & & & & & & & \\
\hline - \% MCE & 30,2 & 34,2 & 26,4 & 36,0 & 24,9 & 29,5 & 35,5 & 36,5 \\
- \% CV & 17,8 & 20,5 & 15,5 & 21,5 & 14,3 & 17,8 & 21,3 & 21,8 \\
\hline Paleta & & & & & & & & \\
\hline - \% MCE & 18,7 & 18,3 & 19,1 & 18,2 & 18,2 & 20,90 & 19,2 & 17,1 \\
- \% CV & 10,9 & 11,0 & 11,1 & 10,9 & $10,3^{\mathrm{b}}$ & $12,6^{\mathrm{a}}$ & $11,6^{\text {ab }}$ & $10,2^{\mathrm{b}}$ \\
\hline Lombo & & & & & & & & \\
\hline -\% MCE & 12,1 & 11,0 & 11,6 & 11,6 & 12,7 & 9,4 & 11,4 & 11,8 \\
-\% CV & 7,0 & 6,6 & 6,7 & 6,9 & 7,3 & 5,7 & 6,8 & 7,1 \\
\hline Costela & & & & & & & & \\
\hline -\% MCE & 17,4 & 15,8 & 17,8 & 15,9 & 19,6 & 14,4 & 15,3 & 16,5 \\
-\% CV $^{*}$ & 10,2 & 9,5 & 10,3 & 9,6 & $11,1^{\text {a }}$ & $8,7^{\text {b }}$ & $9,2^{\text {ab }}$ & $9,9^{\text {ab }}$ \\
\hline
\end{tabular}

* - Médias seguidas de letras diferentes, nas linhas, diferem estatisticamente, ao nivel de $5 \%$ de probabilidade, pelo teste $t$.

Foi observada uma tendência dos animais que receberam maior nível de energia e daqueles que receberam maior nível de proteína de apresentarem maior rendimento de pernil. Animais que receberam menos energia tiveram uma tendência de apresentar maior rendimento de paleta. Isso deve ocorrer não só pelo fato dos animais com dieta menos energética terem desenvolvido menos o trem posterior mas também pelo maior acúmulo de gordura e a maior massa muscular estarem no pernil. Os rendimentos de came e os teores de gordura para pernil e paleta em relação a meia carcaça foram os seguintes , respectivamente: came $=23,36$ e $12,10 \%$; gordura $=4,06$ e $1,73 \%$. Os animais que receberam dietas mais energéticas apresentam maior teor de gordura no pernil e menor na paleta $(12,14$ e $8,65 \%)$ do que os que receberam dietas com menos 
energia $(6,73$ e 9,4\%). Animais que receberam dietas com maior nível protéico acumularam mais gordura no pernil $(11,74 \%)$ do que os que receberam um nível de $13,5 \%$ de PB $(7,76 \%)$.

Para o rendimento de costela, como essa se constitui em sua maior parte de matéria óssea em proporção a musculatura e a gordura, os animais que apresentaram o maior rendimento foram os que tiveram um menor acúmulo de gordura (T1). Os animais com maior acúmulo de gordura e/ou musculatura, portanto com maiores rendimentos em pernil e paleta tiveram menor rendimento de costela . Para o lombo (longisimus dorsi), como este corte contém apenas carne, houve uma tendência dos animais que tiveram menor rendimento em carne e maior acúmulo de gordura, T2 e T3, em apresentarem menores valores de rendimento em lombo.

González-Jiménez (1995) relata os seguintes rendimentos para os cortes comerciais e seu percentual em carne e ossos, respectivamente : Pernil, $32,5 \%$ sendo $83,3 \%$ de carne e $10,5 \%$ de ossos; paleta, $19,6 \%$, com $86,7 \%$ de carne e $13,6 \%$ de ossos; lombo, $21 \%$, com $83,2 \%$ de carne e $16,8 \%$ de ossos; peito, $10,4 \%$, com $83,5 \%$ de carne e $16,5 \%$ de ossos. Assaf \& Cruz (1976) observaram que o pernil apresenta $2,22 \%$ de gordura, enquanto a paleta apresenta somente $0,41 \%$, sendo as partes com maior teor de gordura o acém e o peito. Albuquerque (1993) encontrou para animais de $35 \mathrm{~kg}$ de PV os seguintes

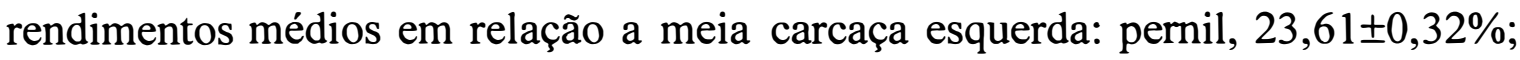
paleta, $17,27 \pm 0,88 \%$; lombo, $12,30 \pm 0,74 \%$; e costela, $9,00 \pm 0,12 \%$.

Em relação ao peso da meia carcaça esquerda, os animais deste experimento apresentaram menores rendimentos apenas para lombo em comparação com os dados médios de literatura. Em relação ao corpo vazio os resultados são inferiores aos da literatura em todos os cortes exceto para costela. 
Isto se deve, possivelmente, ao fato dos animais deste estudo serem mais novos do que os dos trabalhos anteriormente citados. Animais mais velhos além de maior massa muscular em relação ao esqueleto, apresentam também menores proporções relativas de cabeça e patas.

A Tabela 17 apresenta a análise das medidas lineares de carcaça dos animais abatidos no experimento. Não houve diferenças estatísticas significativas $(p>0,05)$ entre os níveis de proteína bruta e energia bruta e suas interações para comprimento do rádio e da tíbia, $13,27 \pm 1,47 \mathrm{~cm}$ e $17,01 \pm 0,42 \mathrm{~cm}$ , respectivamente. Animais que receberam menos energia tiveram carcaças menores, com menor circunferência corporal média e foram mais altos $(\mathrm{p}<0,05)$, embora não tenha havido diferenças significativas $(\mathrm{p}>0,05)$ para estas variáveis quanto ao nível de proteína e para as interações de PB X EB. As capivaras que receberam rações com maior nível protéico e com maior nível energético tiveram maior área de olho de lombo $(\mathrm{p}<0,05)$. 
Tabela 17 : Análise de medidas lineares de carcaça de capivaras $(H . h$. hydrochaeris L., 1766) em crescimento recebendo dietas com diferentes níveis de PB (\%) e EB ( $\mathrm{kcal} / \mathrm{kg})$.

\begin{tabular}{|c|c|c|c|c|c|c|}
\hline & $\begin{array}{c}\text { Compri- } \\
\text { mento da } \\
\text { carcaça } \\
(\mathrm{cm})^{*}\end{array}$ & $\begin{array}{c}\text { Perímetro } \\
\text { corporal } \\
\text { médio } \\
(\mathrm{cm})^{*}\end{array}$ & $\begin{array}{c}\text { Área } \\
\text { do olho } \\
\text { do } \\
\text { lombo } \\
\left(\mathrm{cm}^{2}\right)^{*}\end{array}$ & $\begin{array}{l}\text { Altura } \\
(\mathbf{c m})^{*}\end{array}$ & $\begin{array}{c}\text { Com- } \\
\text { pri- } \\
\text { mento } \\
\text { do } \\
\text { rádio } \\
\text { (cm) } \\
\end{array}$ & $\begin{array}{c}\text { Com- } \\
\text { primen } \\
\text { to da } \\
\text { tíbia } \\
(\mathrm{cm})\end{array}$ \\
\hline \multicolumn{7}{|l|}{$\begin{array}{l}\text { Médias dos E- } \\
\text { feitos Principais }\end{array}$} \\
\hline PB1 $=13,5 \%$ & 68,2 & 67,93 & $27,12^{6-}$ & 41,55 & 13,9 & 16,77 \\
\hline $\mathrm{PB} 2=20,0 \%$ & 69,05 & 66,8 & $35,45^{\mathrm{a}}$ & 42,45 & 12,65 & 17,25 \\
\hline$E B 1=4.000 \mathrm{kcal}$ & $66,55^{\mathrm{b}}$ & $66,25^{\mathrm{b}}$ & $27,52^{b}$ & $45^{\mathrm{a}}$ & 13,55 & 17,1 \\
\hline $\mathrm{EB} 2=4.500 \mathrm{kcal}$ & $70,7^{\mathrm{a}}$ & $68,46^{\mathrm{a}}$ & $33,07^{\mathrm{a}}$ & $39^{\mathrm{b}}$ & 13 & 16,92 \\
\hline \multicolumn{7}{|l|}{$\begin{array}{l}\text { Médias das } \\
\text { Interações }\end{array}$} \\
\hline PB1 X EB1(T1) & 68,3 & 69,5 & $26,50^{6}$ & $\overline{45,5}$ & 15,25 & 16,6 \\
\hline PB2 X EB1(T2) & 64,8 & 63 & $29,56^{\mathrm{ab}}$ & 44,5 & 11,86 & 17,6 \\
\hline PB1 X EB2(T3) & 68,1 & 66,37 & $27,75^{\mathrm{b}}$ & 37,6 & 12,53 & 16,95 \\
\hline PB2 X EB2(T4) & 73,3 & 70,6 & $38,40^{\mathrm{a}}$ & 40,4 & 13,45 & 16,9 \\
\hline
\end{tabular}

Nos animais que receberam rações com maior nível de proteína, foi observado, entretanto, uma tendência a um maior desenvolvimento em comprimento, altura e tamanho da tíbia com uma menor circunferência corporal (animais longilíneos). Os animais que receberam dieta com menos energia também apresentaram um aspecto mais longelíneo. Animais que receberam menos proteína e aqueles que receberam mais gordura apresentaram um crescimento mais lento, contudo mais uniforme, com desenvolvimento tanto em largura como em comprimento, sendo entretanto mais baixos (animais brevilíneos). 
Os animais do experimento apresentaram um volume (em que volume $=$ altura $\mathrm{X}$ comprimento $\mathrm{X}$ diâmetro) médio estimado de $0,062 \pm 0,007$ $\mathrm{m}^{3}$, não havendo diferença significativa $(\mathrm{p}>0,05)$ entre os tratamentos. Contudo, ao ser analisada a relação perímetro corporal/altura, encontrou-se a mesma tendência descrita anteriormente, animais que receberam dietas com mais proteína e dietas com menos energia apresentaram valores menores (1,58 e 1,48, respectivamente) do que animais que receberam dietas com menos proteína e dietas com mais energia (1,65 e 1,75, respectivamente).

Esses resultados confirmam a hipótese de que a capivara, assim como os potros jovens, também sofreria um desenvolvimento do esqueleto muito acelerado quando recebendo ração concentrada com excesso de proteína ou com pouca energia para metabolizar o excedente protéico. Como os animais do experimento encontravam-se confinados, ou seja, sujeitos a uma menor movimentação e atividade natatória, este fato foi agravado com consequente menor desenvolvimento e menor elasticidade da musculatura. Em potros, os exercícios físicos e/ou a restrição no fornecimento de suplementação de concentrados são recomendados para diminuir a incidência de epifisite (Rezende et al. , 1996).

Albuquerque (1993) encontrou os seguintes valores médios para medidas lineares de machos inteiros, machos castrados e fêmeas com cerca de 35 kg de PV e idade de 419 dias : altura, 53,25 $\pm 0,55 \mathrm{~cm}$; comprimento, 74,16 $\pm 2,44$ $\mathrm{cm}$; e perímetro torácico, $71,91 \pm 0,90 \mathrm{~cm}$. A relação média perímetro/ altura $(1,35)$ para os resultados obtidos por essa autora , foi inferior ao valor médio encontrado nesse experimento $(1,61)$ o que pode estar relacionado a menor idade dos animais desse estudo. 
Resumindo o que foi exposto, através da análise conjunta das variáveis GDP, consumo diário, conversão alimentar, taxa de mortalidade e parâmetros de análise quantitativa de carcaça, podem ser feitas as seguintes inferências: os animais que receberam dietas contendo um nível de EB de 4.000 $\mathrm{kcal} / \mathrm{kg}$ e um nível de PB de $20 \%$ apresentaram um maior desenvolvimento corporal e um maior GDP, contudo apesar de terem melhores taxas de conversão alimentar, não aproveitaram eficientemente a proteína que lhes foi fornecida transformando esse excesso em gordura, que se constituiu na realidade em uma boa parte de seu ganho de peso. Logo, para o nível energético de $4.000 \mathrm{kcal}$ de $\mathrm{EB} / \mathrm{kg}$, o nível protéico ótimo para proporcionar maiores ganhos de peso e maior eficiência protéica deve ser um valor intermediário entre os dois níveis de PB testados.

Animais que receberam dietas com $4.500 \mathrm{kcal}$ de EB/kg apresentaram um desempenho inferior aos tratamentos com nível de $4.000 \mathrm{kcal}$ de $\mathrm{EB} / \mathrm{kg}$. Isto deveu-se a uma menor ingestão de MS, o que levou a uma redução da ingestão dos outros nutrientes. Possivelmente, o ajuste do nível de proteína bruta a esse maior nível energético proporcione melhores resultados, visto que, os animais tiveram melhor performance quando receberam 20\% de PB nesse nível energético. Contudo, assim como foi observado para o nível de $4.000 \mathrm{kcal}$ de $\mathrm{EB} / \mathrm{kg}$, um nível protéico de $20 \%$ de $\mathrm{PB}$ já representa um excesso de ingestão protéica, sendo esse excesso utilizado como fonte de energia. $\mathrm{O}$ nível ótimo de PB deve se encontrar entre os valores de 13,5\% e 20\% também para esse nível de EB. O nível protéico de $20 \%$ de $\mathrm{PB}$ até poderia ser utilizado, mas em dietas com maior nível energético.

Como os animais que receberam maior nível energético tiveram menores taxas de incidência de doenças e menores taxas de mortalidade, seria mais recomendável utilizar para capivaras em crescimento, principalmente, no 
caso de animais submetidos a uma maior carga de estresse, maiores níveis energéticos (maior ou igual a $4.500 \mathrm{kcal} \mathrm{de} \mathrm{EB} / \mathrm{kg}$ ) e um maior nível de proteína bruta, intermediário entre 13,5 e $20 \%$ de $\mathrm{PB}$ e ajustado a esse maior nível energético, para que haja um melhor desempenho do animal com uma maior eficiência protéica e uma maior resistência ao estresse e às doenças.

\subsection{Experimento I-B: Diferentes tipos de dieta e de áreas de confinamento:}

\subsubsection{Ganho de peso, consumo em matéria seca e conversão alimentar:}

Para analisar a influência do grau de confinamento e da presença ou não de capim na alimentação de capivaras em crescimento, durante o acompanhamento dos blocos III, IV e V da parte A do Experimento I, animais de peso e idade similares aos dos animais do experimento anterior foram distribuídos em grupos que receberam os seguintes tratamentos: $\mathrm{G} 2=6$ animais confinados em baias experimentais ( 1 cabeça/ $20 \mathrm{~m}^{2}$ ) recebendo apenas capim elefante; $G 3=6$ animais semiconfinados $\left(1\right.$ cabeça/ $70 \mathrm{~m}^{2}$ ) recebendo ração peletizada com $17 \%$ de $\mathrm{PB}, 4200 \mathrm{kcal}$ de $\mathrm{EB} / \mathrm{kg}$ e $3 \%$ de fibra bruta (FB); e G4= 6 animais semiconfinados ( 1 cabeça/70 $\mathrm{m}^{2}$ ) recebendo capim elefante mais ração

farelada à base de rolão de milho e farelo de soja com $18 \%$ de PB, $3.300 \mathrm{kcal}$ de $\mathrm{EB} / \mathrm{kg}$ e $16,5 \%$ de $\mathrm{FB}$. Os animais dos blocos III, IV e V do experimento I-A constituíram o grupo Gl (animais confinados recebendo ração peletizada).

A Tabela 18 apresenta os valores médios de GDP, consumo de matéria seca e conversão alimentar para os animais dos diferentes grupos . Não houve diferenças significativas $(p>0,05)$, pelo teste $t$, entre os animais que receberam apenas ração peletizada (confinados e semiconfinados) e os animais 
semiconfinados que receberam ração farelada mais capim. Animais que receberam somente capim tiveram GDP significativamente menor que os demais, e aqueles que foram alimentados apenas com ração (confinados e semiconfinados) apresentaram menor consumo diário de MS e melhor conversão alimentar do que os animais que receberam só capim ou capim mais ração farelada.

Tabela 18 : Ganho médio diário de peso, consumo de MS e conversão alimentar de capivaras em crescimento sob diferentes dietas e áreas de confinamento.

Grupos ou tratamentos

Médias

N GDP (g) ${ }^{*} \quad$ Consumo Conversão

$\operatorname{deMS}(\mathbf{g})^{* *}$ Alimentar ${ }^{* *}$

\begin{tabular}{lllll}
\hline G1- Confinado alimentado & 12 & $67,09 \pm 26,5^{\mathrm{a}}$ & $312,29 \pm 54,9^{\mathrm{a}}$ & $5,1: 1^{\mathrm{a}}$
\end{tabular} com ração peletizada

G2- Confinado alimentado $\quad 6 \quad 18,80 \pm 5,3^{\mathrm{b}} \quad 430,93 \pm 83,2^{\mathrm{b}} \quad 22,2: 1^{\mathrm{b}}$ com capim elefante

G3- Semiconfinado $\quad 6 \quad 52,65 \pm 26,9^{\mathrm{a}} \quad 337,11 \pm 71,7^{\mathrm{a}} \quad 8,64: 1^{\text {ab }}$

alimentado com ração

peletizada

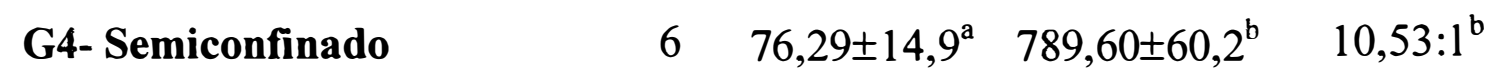

alimentado com ração

farelada + capim elefante

$\mathrm{CV}$ de $\mathrm{GDP}=39,03 \%$; $\mathrm{CV}$ de consumo de $\mathrm{MS}=13,06 \% ; \mathrm{CV}$ de conversão alimentar=37,75\%.

* - Médias seguidas de mesma letra, na coluna, não diferem estatísticamente, ao nível de $5 \%$ pelo teste $\mathrm{t}$ ; ** - Médias seguidas de mesma letra, na coluna, não diferem estatísticamente, ao nível de $1 \%$ pelo teste $\mathrm{t}$. 
A Tabela 19 apresenta os valores de probabilidade do teste F para os contrastes dos tratamentos feitos a partir da análise de variância dos mesmos.

Tabela 19 : Valores de probabilidade do teste F na comparação por contrastes ortogonais de GDP médio, consumo médio de MS e conversão alimentar de capivaras em crescimento submetidas à diferentes dietas e áreas de confinamento.

\section{Prob>F}

CONTRASTES

GDP (g) Consumo Conversão de MS (g) Alimentar

\section{TIPO DE DIETA:}

\begin{tabular}{llll}
\hline 1 - Capim X ração concentrada & 0,004 & 0,0013 & 0,0001
\end{tabular}
(confinado)
2- Capim X ração farelada comum +
0,003
0,0001
0,0001 capim (semiconfinado)

3- Ração farelada comum+capim

0,19

0,0001

0,049

(semiconfinado) $X$ ração concentrada

3.1- Semiconfinado $X$ confinado $\quad 0,47 \quad 0,0001 \quad 0,006$

3.2 - Semiconf. X semiconfinado $\quad 0,13 \quad 0,0001 \quad 0,005$

SISTEMA DE CRIAÇÃO:

1- Confinado X semiconfinado

0,80

$0,0001 \quad 0,005$

2- Ração concentrada confinado X ração $\quad 0,26$

0,412

0,062 concentrada semiconfinado

Analisando-se as Tabelas 18 e 19 em conjunto, verifica-se que os animais que receberam somente capim tiveram desempenho inferior a todos os outros grupos, apresentando o menor GDP $(18,80 \pm 5,3 \mathrm{~g} / \mathrm{dia})$ e o pior valor de 
conversão alimentar 22,2:1. Pelo que foi observado durante o experimento além de apresentarem um desempenho bastante inferior, os animais alimentados apenas com capim elefante apresentavam um aspecto geral de debilidade, tornando-se extremamente magros e com pêlos sem brilho, $25 \%$ desses animais morreram durante este ensaio. Para evitar que o mesmo acontecesse com os demais animais deste tratamento, eles foram retirados do experimento e passaram a receber ração farelada, após um período experimental de 70 dias .

Segundo Parra et al. (1978) animais com cerca de 16 a $19 \mathrm{~kg}$ de PV alimentados apenas com capim elefante apresentaram um GDP de 40,6 g enquanto que animais alimentados com $50 \%$ de capim e $50 \%$ de ração com $18 \%$ de PB tiveram um GDP médio de 127,3 g. González-Jiménez (1995) observou que animais entre 15 e $20 \mathrm{~kg}$ de PV apresentam uma conversão alimentar de 15,12:1 e que em animais com 20 a $25 \mathrm{~kg}$ de PV, esse valor aumenta para 23,8:1. Parra et al. (1978) encontraram para capivaras alimentadas com $100 \%$ de capim elefante um GDP de 22,7 g, um consumo diário de 3,43 \% do PV e uma conversão alimentar de 22,8:1. Silva Neto (1989) afirma que animais com peso acima dos $20 \mathrm{~kg}$ de $\mathrm{PV}$, perderam cerca de 39,75 g de peso/dia ao serem alimentados apenas com capim elefante, apresentando um consumo de MS de 669 g/dia. Esses valores são similares aos resultados encontrados neste estudo, em que animais alimentados apenas com capim elefante apresentam um desempenho bastante inferior, com um menor GDP, pior conversão alimentar e maior debilidade fisica.

Isso se deve ao fato de que apenas uma forragem não é capaz de atender a todas as exigências nutricionais de capivaras. Na natureza esse animal é extremamente seletivo na escolha das forragens de que se alimenta, consumindo um número reduzido de espécies por período, mas variando bastante essas espécies consumidas ao longo do ano (González-Jiménez \& Escobar, 1977). A 
capivara escolhe as forragens mais ricas em proteína (com cerca de $10 \%$ de PB) e de maior palatabilidade em cada época do ano, consumindo preferencialmente gramíneas (González-Jiménez, 1977). Sob manejo intensivo recebendo apenas capim ou em manejo extensivo em pastagens solteiras sem suplementação, a única opção da capivara para conseguir obter o mínimo de nutrientes necessários para sua manutenção é aumentar sua taxa de ingestão diária, o que resulta em um pior valor de conversão alimentar, contudo, isso muitas vezes não é suficiente, e o animal nem mesmo consegue apresentar um GDP reduzido, passando a perder peso e tornando-se menos saudáveis.

Não foram observadas diferenças estatísticas significativas ( $>0,05)$ para GDP entre os animais que consumiram apenas ração concentrada peletizada (Gl e G3) e aqueles que receberam capim elefante suplementado por ração farelada (G4), embora estes últimos tenham apresentado maiores valores de GDP. Animais confinados que receberam ração concentrada (G1), entretanto, apresentaram GDP mais próximo ao dos animais semiconfinados que recebiam ração farelada e capim (G4). Isto pode indicar que, apesar de terem um menor desempenho devido ao estresse, a uma redução na ingestão de matéria seca e à modificação do ambiente cecal pelo menor nível de fibra bruta, esses fatores devem ser, em parte, compensados pela redução nos gastos energéticos com atividades fisicas, característica do processo de confinamento. Os animais do grupo G3, como encontravam-se semiconfinados, tiveram maiores gastos energéticos e apresentaram um menor valor de GDP.

As capivaras que receberam ração concentrada peletizada apresentaram um menor consumo de MS em relação aos animais que foram alimentados com capim e ração farelada (G4). A conversão dos animais confinados recebendo ração peletizada foi melhor do que os animais de G4, 
entretanto, estes últimos não diferiram em termos de conversão alimentar dos animais de G3.

Parra et al. (1978) obtiveram para animais de 15 a $20 \mathrm{~kg}$ de PV, alimentados com capim elefante e ração com 14 \% (proporção de 60:40) e com capim mais ração com 18 \% de PB (proporção de 50:50) ganhos médios diários de peso de 120,4 e 127,2 g/dia, respectivamente. Silva Neto (1989) encontrou para animais acima dos $20 \mathrm{~kg}$ de $\mathrm{PV}$, alimentados com capim elefante e ração de 16,25\% de PB ad libitum, um GDP de 129,76 g/dia. Esse mesmo autor observou que o GDP reduzia para $48,24 \mathrm{~g} /$ dia quando a ração era restringida a $35 \%$ do consumo ad libitum do tratamento anterior. Para animais alimentados apenas com ração, Silva Neto (1989) encontrou um GDP de 100,11 g/dia.

Silva Neto (1989) encontrou valores de consumo de 797,59 e 588,5 g de MS/dia e de conversão alimentar de 12,4:1 e 6,69:1, para animais alimentados com capim e ração com $16,25 \%$ de PB e somente com ração, respectivamente. Esses resultados foram piores do que os encontrados no presente estudo.

Não houve diferenças estatísticas significativas $(p>0,05)$ para GDP entre animais confinados e semiconfinados. Os animais de Gl, apesar do estresse conseguiram apresentar um bom desempenho. Animais confinados tiveram menor consumo e melhor conversão alimentar do que animais semiconfinados. Animais que receberam ração concentrada semiconfinados não diferiram ( $p>0,05)$ em GDP, consumo de MS e conversão alimentar daqueles que foram confinados e receberam o mesmo tipo de dieta. Todavia, animais confinados apresentaram uma taxa de mortalidade de $20 \%$, enquanto nenhum dos animais semiconfinados morreu. Isto deveu-se a maior carga de estresse e manejo a qual os animais de G1 estavam submetidos. 
Ojasti \& Sosa Burgos (1985) estudando a influência do tamanho do grupo (5, 10 e 15 animais) e do tamanho de piquetes $\left(32\right.$ e $130 \mathrm{~m}^{2}$ ) para capivaras em cativeiro, encontraram influência apenas do tamanho do grupo sobre o número de interações agonistas individuais, a performance reprodutiva e a taxa de mortalidade que foram maiores nos grupos com 15 indivíduos adultos. Os resultados foram aproximadamente os mesmos em piquetes grandes e pequenos, não sendo detectado nenhum efeito do tamanho da área das instalações. $O$ tamanho mínimo de grupo no menor piquete do experimento de Ojasti \& Sosa Burgos (1985) apresenta uma densidade de 1 cabeça/ $6,4 \mathrm{~m}^{2}$, densidade muito maior do que a utilizada para os animais confinados em baias no presente experimento, o que reforça a hipótese de que a maior mortalidade dos animais confinados foi devida ao estresse e aos raumatismos causados pelo manejo e pelas pesagens.

\subsubsection{Parâmetros de carcaça :}

Os valores obtidos para os animais confinados (G1) e para a média dos animais em piquetes (G3 e G4) foram, respectivamente: peso do corpo vazio $(24,13 \pm 4,89$ e $27,67 \pm 6,36 \mathrm{~kg})$; carcaça quente $(15,44 \pm 3,43$ e $16,55 \pm 2,05$ $\mathrm{kg})$; rendimento da carcaça em relação ao peso do corpo vazio $(63,86 \pm 3,70 \mathrm{e}$ $64,02 \pm 2,21 \%)$; rendimento de came $(68,97 \pm 3,70 ; 67,05 \pm 4,32 \%)$; comprimento da carcaça $(69,18 \pm 4,31 ; 74,25 \pm 1,06 \mathrm{~cm})$; perdas por resfriamento $(5,36 ; 4,50 \%)$; rendimento em pernil $(31,88 \pm 6,68 ; 33,17 \pm 2,79 \%)$ e rendimento em lombo $(11,62 \pm 1,78 ; 10,44 \pm 0,35 \%)$. Não existem diferenças significativas para essas variáveis.

Diferenças estatísticas significativas $(\mathrm{p}<0,05)$ foram observadas para teor de gordura entre os animais confinados e semiconfinados. Animais 
criados em semiconfinamento com ração farelada e capim apresentaram um menor teor de gordura corporal, 8,81 \%, que os animais tratados com ração peletizada em semiconfinamento, 20,70\%, e em confinamento, $16,88 \%$ (vide Tabela 20).

Tabela 20: Análise quantitativa de carcaças de capivaras (H. h. hydrochaeris L., 1766) confinadas e semiconfinadas alimentadas com diferentes dietas.

\begin{tabular}{|c|c|c|c|}
\hline & \multicolumn{3}{|c|}{ Médias dos tratamentos } \\
\hline & $\begin{array}{c}\text { Ração } \\
\text { Peletizada }+ \\
\text { Confinamento } \\
\end{array}$ & $\begin{array}{l}\text { Ração Peletizada }+ \\
\text { Semiconfinamento }\end{array}$ & $\begin{array}{c}\text { Ração Farelada e } \\
\text { Capim }+ \\
\text { Semiconfinamento }\end{array}$ \\
\hline $\begin{array}{l}\text { - Carcaça } \\
\text { Quente (kg) }\end{array}$ & 15,86 & 16,17 & 15,48 \\
\hline $\begin{array}{l}\text { - Rendimento de } \\
\text { Carcaça (\%) }\end{array}$ & 63,85 & 65,59 & 62,46 \\
\hline $\begin{array}{l}\text { - Rendimento em } \\
\text { Carne (\%) }\end{array}$ & 68,98 & 70,10 & 64,01 \\
\hline $\begin{array}{l}\text { - Teor de } \\
\text { Gordura (\%) }\end{array}$ & $16,88^{\mathrm{a}}$ & $20,70^{a}$ & $8,81^{b}$ \\
\hline $\begin{array}{l}\text { - Peso do Couro } \\
\text { (kg) }{ }^{1}\end{array}$ & $2,18^{b}$ & $2,75^{\mathrm{a}}$ & $2,19^{\mathrm{ab}}$ \\
\hline
\end{tabular}

$\mathrm{Na}$ Tabela 21 são apresentados os rendimentos dos cortes comerciais para cada grupo. Não houve diferenças estatísticas significativas $(p>0,05)$ para os cortes de pernil, paleta e lombo entre os grupos (G1,G3 e G4). Animais criados em áreas maiores tendem a apresentar um maior rendimento de pernil do que animais criados confinados, que tendem a apresentar um maior rendimento em paleta e em lombo e têm um maior rendimento de costela. 
Tabela 21: Rendimento dos cortes comerciais de capivaras $(H . h$ hydrochaeris L., 1766) confinadas e semiconfinadas com diferentes dietas.

\begin{tabular}{|c|c|c|c|}
\hline & \multicolumn{3}{|c|}{ Médias dos tratamentos } \\
\hline & $\begin{array}{c}\text { Ração } \\
\text { peletizada }+ \\
\text { Confinamento } \\
\end{array}$ & $\begin{array}{l}\text { Ração Peletizada }+ \\
\text { Semiconfinamento }\end{array}$ & $\begin{array}{c}\text { Ração farelada e } \\
\text { capim }+ \\
\text { Semiconfinamento }\end{array}$ \\
\hline Pernil - \% MCE & 31,88 & 31,20 & 35,15 \\
\hline$-\% \mathrm{CV}$ & 18,95 & 20,575 & 19,91 \\
\hline Paleta - \% MCE $^{1}$ & 18,31 & 17,58 & 16,66 \\
\hline$-\% C V^{2}$ & 10,86 & 11,18 & 9,63 \\
\hline Lombo-\% MCE & 11,62 & 10,69 & 10,19 \\
\hline$-\% \mathrm{CV}$ & 6,85 & 7,06 & 5,75 \\
\hline Costela-\% MCE * & $16,72^{\mathrm{a}}$ & $12,13^{b}$ & $14,97^{\mathrm{ab}}$ \\
\hline$-\% \mathrm{CV}^{*}$ & $9,87^{\mathrm{a}}$ & $7,98^{\mathrm{b}}$ & $8,48^{a b}$ \\
\hline
\end{tabular}

1- Médias ajustadas pela covariável peso da meia carcaça esquerda resfriada.

2- Médias ajustadas pela covariável peso do corpo vazio.

* - Médias seguidas de letras diferentes, nas linhas, diferem estatisticamente, ao nível de $5 \%$ pelo teste $t$.

Embora não tenha havido diferenças significativas para a maioria das variáveis analisadas, os animais criados em semiconfinamento ( 1 cabeça/70 $\mathrm{m}^{2}$ ) tenderam a apresentar um desempenho superior em relação aos animais confinados. Silva Neto (1989) observou que animais que dispunham de tanques para banhos de imersão e atividades natatórias apresentavam maiores GDP (0,52\% do PV ) e melhor conversão alimentar (7,83:1)quando comparados com animais sem acesso aos tanques (GDP $=0,39 \%$ do PV e conversão alimentar de 13,13:1). Esses resultados mostram que a capivara tende a apresentar maior desenvolvimento quando possui maiores condições para movimentação e ouras atividades, o que parece advir não só de uma maior atividade física como também da redução do estresse do cativeiro. 


\subsection{Experimento I-C : Diferentes idades iniciais de arraçoamento (70 e 150 dias):}

Na Tabela 22 é mostrado o efeito das diferentes idades iniciais de arraçoamento das capivaras utilizadas no experimento I-A sobre as médias de GDP, consumo diário de MS e conversão alimentar. Não foram observadas diferenças estatísticas significativas $(p>0,05)$ para as variáveis GDP e conversão alimentar. Os animais que começaram a receber ração mais precocemente apresentaram um maior consumo.

Assim como pode ser observado nas capivaras deste experimento, o aleitamento restrito ou desmame precoce afetam o desempenho de bezerros e aumentam linearmente sua ingestão de forragens (Lusby et al., 1976; Sowell et al., 1996). Estes efeitos podem ser amenizados por um maior período até a separação das mães e pela qualidade do alimento fornecido (Neville \& McCormick, 1981).

Tabela 22 : Ganho diário de peso, consumo diário de ração em MS (CDR) e conversão alimentar de capivaras com diferentes idades iniciais de arraçoamento.

\begin{tabular}{lcccc}
\hline IDADE & \multicolumn{2}{c}{ Médias } & Prob $>$ F & Prob $>|\mathbf{T}|$ \\
\cline { 2 - 3 } & $\mathbf{7 0}$ dias & $\mathbf{1 5 0}$ dias & & \\
\hline GDP (g) & $\mathbf{7 8 , 0 2 \pm 2 5 , 7}$ & $\mathbf{7 4 , 4 9 \pm 1 5 , 1}$ & 0,77 & 0,7423 \\
CDR (g) & $339,70 \pm 40,9^{\mathrm{b}}$ & $285,50 \pm 53,3^{\mathrm{a}}$ & 0,06 & 0,0387 \\
Conversão & $4,75: 1$ & $3,88: 1$ & 0,12 & 0,1538 \\
Alimentar & & & & \\
\hline
\end{tabular}

$\mathrm{CV}$ de GDP $=30,34 \% ; \mathrm{CV}$ de $\mathrm{CDR}=15,99 \% ; \mathrm{CV}$ de $\mathrm{CA}=23,13 \%$.

*- Médias seguidas de mesma letra, na linha, não diferem estatísticamente ao nível de $5 \%$ pelo teste $t$. 
Na Figura 7 são apresentadas as curvas de crescimento para os animais que foram confinados nas baias experimentais e começaram a receber ração com 70 e com 150 dias. As regressões quadráticas apresentaram um ajuste regular $\left(r^{2}=0,66\right.$ e 0,63$)$ aos valores observados pelo fato que este período inicial (até aos 10 meses de idade) pode ser considerado um período de crescimento tendendo ao exponencial.

Pode-se observar que os animais que foram confinados e começaram a receber a ração experimental somente aos 150 dias, apresentaram um desenvolvimento mais lento do que os que começaram aos 70 dias. $\mathrm{O}$ desmame natural da capivara ocorre por volta dos 90-120 dias (Ojasti, 1973), sendo que, animais nascidos no cativeiro do projeto da CIZBAS/ESALQ/USP, quando permanecem no grupo após esse período, se alimentam da mesma dieta do grupo de reprodução. A mudança do leite para outra dieta é feita gradualmente e como, em geral, a dieta dos adultos é uma ração suplementar ao fornecimento de capim, com baixo nível protéico e energético (14\% PB e $3200 \mathrm{kcal} / \mathrm{kg}$ ), é possivel que não atenda às exigências dos filhotes e estes acabam por ter uma redução no seu desenvolvimento.

Foram registrados os ganhos médios diários de peso de quatro filhotes que foram mantidos junto com o grupo de reprodução mesmo depois de 90 dias. O GDP médio desses animais foi maior (93,48 g/dia) do que os animais que foram confinados e receberam ração (74,49 e 78,02 g/dia). Entretanto, o GDP até os 90 dias, dos animais que permaneceram com as mães, que foi de 109,89 g/dia caiu para 86,30 g/dia aos 190 dias, o que está relacionado não só à redução da velocidade de crescimento devido a idade mas, possivelmente também, ao não atendimento das exigências nutricionais das capivaras em crescimento. Esse problema pode ser minimizado com a adoção do sistema de "creep feeding", permitindo apenas o acesso dos filhotes a uma ração concentrada mais energética 
e protéica, evitando que eles sofram deficiência nutricional nessa fase da mesma forma como é feito para os potros jovens (Rezende et al., 1996).

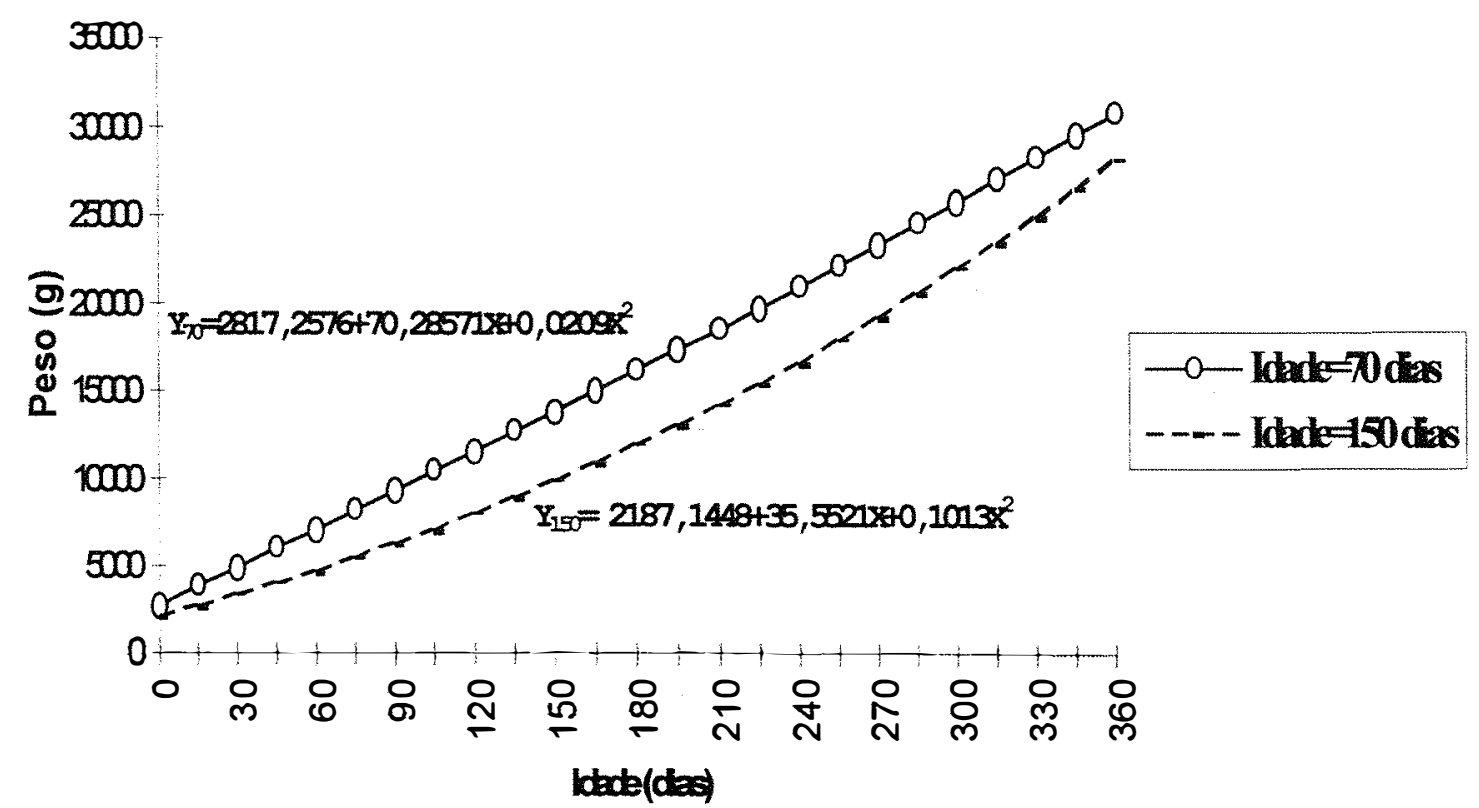

Figura 7 : Curvas de crescimento de capivaras (H. h. hydrochaeris L. , 1766) com diferentes idades iniciais de arraçoamento e confinamento.

Apesar do crescimento inicial mais lento, os animais que começaram a receber a ração experimental somente aos 150 dias, não diferem dos que começaram a receber aos 70 dias em termos de GDP e, ao serem analisadas as curvas de crescimento verifica-se que acima dos 10 meses (300 dias) de idade as diferenças entre os dois grupos seriam menores, o que parece indicar um possível ganho de peso compensatório nos animais.

Os animais que foram confinados e começaram a receber ração experimental aos 70 dias apresentaram uma taxa de mortalidade de 30,3\%, enquanto que nos animais de 150 dias não houve nenhum óbito. Isso foi devido 
não só ao maior estresse pela separação precoce das mães e mudança abrupta de alimentação mas, provavelmente, devido a maior fragilidade desses animais e ao manejo durante o experimento (captura para as pesagens) e talvez a uma menor resistência a doenças proporcionada pelo desmame precoce.

Além do que foi observado pode-se acrescentar que, os animais que são confinados e começam a receber uma ração concentrada que atenda melhor a suas exigências mais tardiamente irão apresentar junto a um menor consumo e uma menor susceptibilidade a doenças com menor taxa de mortalidade, também uma menor demanda de mão-de-obra para a alimentação (recebem a alimentação até aproximadamente 5 meses na mesma baia da mãe) e um menor período de arraçoamento (considerando-se o abate aos 10 meses, seriam necessários somente 150 dias versus 230 dias dos animais de 70 dias). Outro fator importante está no processo de aprendizado desses animais (Azcaráte, 1978), por serem animais extremamente gregários, quanto mais tempo o filhote permanece no grupo mais condições terá de observar e aprender o comportamento dos animais adultos : processo de corte, parição e cria de filhotes, estabelecimento de hierarquia, etc.(Nogueira Filho ${ }^{1}$ ).

Desmamar os filhotes mais tardiamente seria então, por essa série de fatores, mais conveniente, entretanto deve ser ressaltado que a dificuldade para formar os grupos de filhotes para engorda aumenta à medida que estes ficam mais velhos e pesados (Souza et al., 1989). Portanto, deve-se conciliar o desmame tardio a um bom manejo de formação de grupos de filhotes, colocando os filhotes em áreas neutras para os mesmos, no mesmo dia, e de preferência em áreas bem grandes, possibilitando a fuga das interações agonísticas mais severas, até que todos os animais do grupo se adaptem.

\footnotetext{
${ }^{1}$ SÉRGIO LUIZ GAMA NOGUEIRA FILHO, MSc., pesquisador do Depto. de Zootecnia/ESALQ/USP. Informação pessoal.
} 
A taxa de mortalidade dos animais de 70 dias poderá ser reduzida com uma menor intensidade de manejo sobre eles (menos estresse e problemas de traumatismos durante as capturas).

Dependendo dos objetivos do criador - produzir animais para um abate precoce aos 8 meses com $20 \mathrm{~kg}$ de $\mathrm{PV}$, produzir reprodutores e matrizes para a venda ou reposição de seu plantel - e do custo da ração, qualquer dos dois sistemas poderá ser adotado.

\subsection{Experimento II : Ensaio de digestibilidade das rações experimentais:}

Os quadros de análise de variância e as tabelas com os coeficientes de digestibilidade de cada tratamento por período experimental são apresentados no Apêndice 2.

Durante o período de coleta, foi adotada restrição de consumo alimentar para evitar que esse fator interferisse na digestibilidade dos nutrientes.

Mesmo selecionando, entre 10 animais, os quatro que mais se adaptaram às condições das gaiolas metabólicas, ainda houve problemas de estresse. Todos os animais escolhidos foram machos. As fêmeas não se adaptaram, apresentando anorexia e diarréia. Nos dois primeiros períodos experimentais do quadrado latino, os animais apresentaram maiores alterações comportamentais (agressividade) e fisiológicas, mesmo havendo um período de adaptação antes de que fosse iniciado cada período de coleta.

Tirar os animais das gaiolas entre um período experimental e outro, levando-os para as baias experimentais e fornecendo ração e capim, parece ter dado resultados, minimizando o estresse que os acometia. $\mathrm{O}$ uso de florais de 
Bach (Rescue), nos dois primeiros períodos, para acalmar os animais também apresentou efeitos. Foi observado que, quando se deixava de fornecer o medicamento por apenas um dia, os animais tornavam-se agitados e alguns apresentavam, inclusive, diarréia. Estes sintomas desapareciam, imediatamente, quando se retomava a medicação. No terceiro e quarto períodos experimentais, os animais se mostraram mais adaptados não apresentando mais nenhum tipo de distúrbio. O uso de florais foi suspenso nesses períodos.

Não houve diferenças estatisticamente significativas $(p>0,05)$ para o consumo de matéria seca (MS), matéria orgânica (MO), energia bruta (EB), extrato etéreo (EE), fibra bruta (FB), fibra em detergente neutro (FDN), fibra em detergente ácido (FDA) e extrativo não nitrogenado (ENN). Houve uma ingestão significativamente maior $(p<0,05)$ de proteína bruta e nitrogênio para os tratamentos com maior nível de PB (20\%). As tabelas com o consumo de nutrientes são mostradas no Apêndice 3.

\subsubsection{Digestibilidade da matéria seca}

Os coeficientes médios de digestibilidade aparente da matéria seca (CDMS) obtidos para as rações experimentais são apresentados na Tabela 23. Rações com maior nível protéico (20\% de PB) apresentaram menor CDMS, não houve diferenças estatisticamente significativas ( $p>0,05$ ), para os CDMS das rações com diferentes níveis de energia bruta nem entre as interações de $\mathrm{PB} X$ EB. 
Tabela 23 : Efeito de níveis de PB e EB sobre os coeficientes de digestibilidade aparente da matéria seca em rações para capivaras em crescimento $(\%)$.

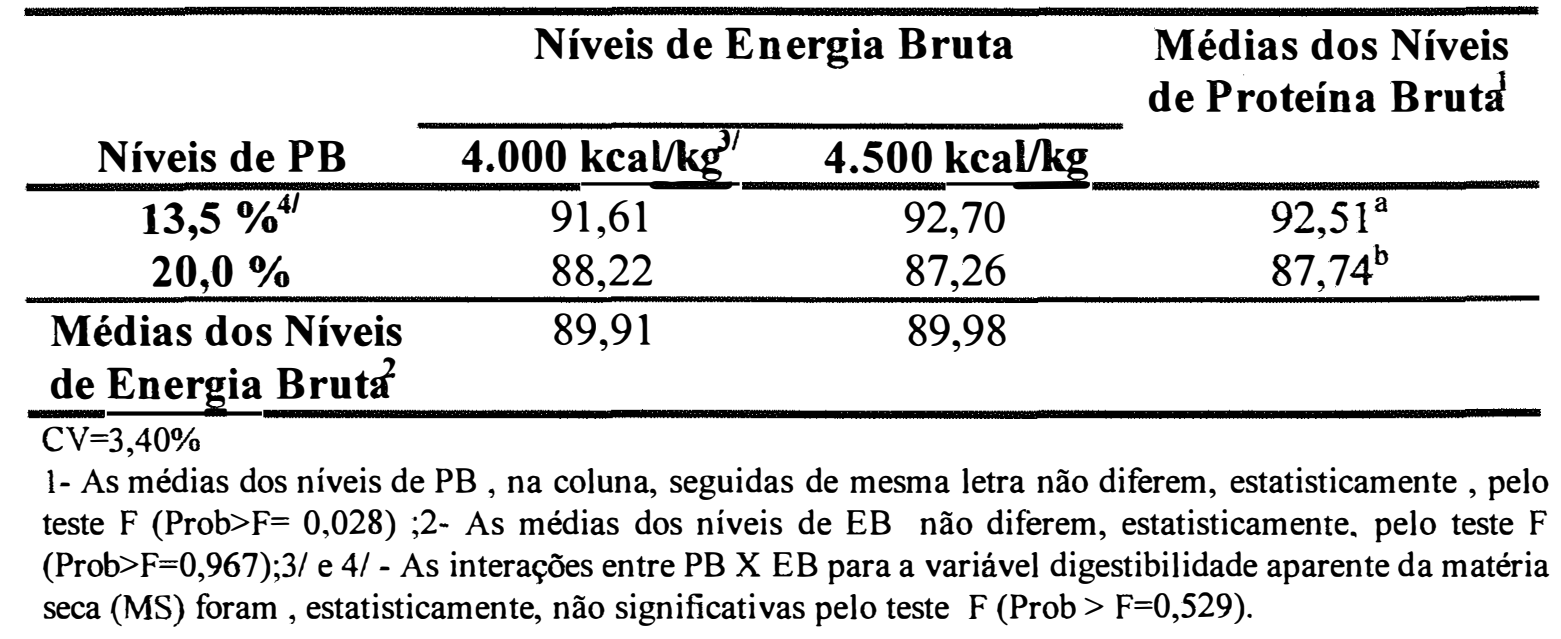

Ojasti (1971) estimou em 53,5, 61,7 e 55,8 \%, os coeficientes de digestibilidade aparente da matéria seca (CMDS) de Paspalum fasciculatum, Brachiaria mutica e Echinochloa polystachya na alimentação de capivaras. González-Jiménez \& Parra (1972) encontraram um coeficiente médio de digestibilidade da matéria seca (CDMS) de $60,75 \%$ para capivaras alimentadas com Brachiaria mutica. Parra \& Escobar (1976) obtiveram coeficientes de digestibilidade da matéria seca de $43,3 \%$ e $52,0 \%$ em capivaras alimentadas, respectivamente, com Paspalum fasciculatum e feno de Cynodon dactylon.

González-Jiménez \& Escobar (1975) observaram em capivaras, de aproximadamente $25 \mathrm{~kg}$ de $\mathrm{PV}$, alimentadas com diferentes proporções de concentrado e volumoso (100:0, 75:25, 50:50, 25:75 e 0:100) os seguintes CDMS : 84,76, 76,06, 67,56, 59,06 e 50,56\%, respectivamente. González-Jiménez et al. (1976) encontraram coeficientes de digestibilidade da MS de 50,5, 64,2, 71,0 e $84,7 \%$ para capivaras alimentadas, respectivamente com $0,40,60$ e $100 \%$ de concentrado na ração.Baldizan et al. (1982) determinaram para capivaras 
alimentadas com feno de Cenchrus ciliaris e 0, 15 e $30 \%$ de farinha de mandioca, respectivamente, $44,6,49,8$ e $56,6 \%$ de digestibilidade aparente sobre a matéria seca.

Bernardi (1993) encontrou para capivaras de cerca de $35 \mathrm{~kg}$ de PV, alimentadas com rações contendo diferentes níveis de volumoso (15, 22, 29, 36 e $43 \%$ ), respectivamente, os seguintes coeficientes de digestibilidade aparente da MS : 77,80, 73,64, 68,28, 65,21 e 60,15\%.

\subsubsection{Digestibilidade da matéria orgânica}

A Tabela 24 apresenta as médias dos coeficientes de digestibilidade aparente da matéria orgânica (CDMO). Rações com menor nível protéico apresentaram maior CDMO. Rações com menor quantidade de energia tenderam a apresentar maiores valores de CDMO.

Tabela 24 : Efeito de níveis de PB e EB sobre os coeficientes de digestibilidade aparente da matéria orgânica em rações para capivaras em crescimento (\%).

\begin{tabular}{|c|c|c|c|}
\hline \multirow[b]{2}{*}{ Níveis de PB } & \multicolumn{2}{|c|}{ Níveis de Energia Bruta } & \multirow{2}{*}{$\begin{array}{l}\text { Médias dos Níveis } \\
\text { de Proteína Bruta }\end{array}$} \\
\hline & $4.000 \mathrm{kcal} / \mathrm{kg}^{3 /}$ & $4.500 \mathrm{kcal} / \mathrm{kg}$ & \\
\hline $13,5 \%$ & 94,30 & 95,22 & $94,76^{\mathrm{a}}$ \\
\hline $20,0 \%$ & 91,82 & 91,72 & $91,77^{\mathrm{b}}$ \\
\hline $\begin{array}{l}\text { Médias dos Níveis } \\
\text { de Energia Bruta2 }\end{array}$ & 93,06 & 93,47 & \\
\hline $\begin{array}{l}C V=1,99 \% \\
\text { 1- As médias dos niveis de } \\
\text { teste } F(P r o b>F=0,01) ; 2 \\
(\text { Prob }>F=0,66) ; 3 / \text { e } 4 /-A s\end{array}$ & $B$, na coluna, & $\begin{array}{l}\text { e mesma letra não } \\
\text { EB não diferem }\end{array}$ & $\begin{array}{l}\text { rem, estatisticamente, pelc } \\
\text { tatisticamente, pelo teste } \\
\text { ilidade aparente da matéri }\end{array}$ \\
\hline
\end{tabular}


Ojasti (1973) determinou um coeficiente de digestibilidade aparente da MO (CDMO) de 53,5\% para capivaras alimentadas com Paspalum fasciculatum. González-Jiménez \& Parra (1972) obtiveram um CDMO médio de 61,7\% para animais que receberam Brachiaria mutica. Para o coeficiente de digestibilidade aparente da matéria orgânica, Bernardi (1993) observou uma média de $71,08 \pm 4,40 \%$ em capivaras de $35,92 \mathrm{~kg}$ de PV submetidas a rações com diferentes níveis de volumoso (15 a 43\%)

\subsubsection{Digestibilidade da proteína bruta}

Os coeficientes médios de digestibilidade aparente da proteína bruta (CDPB) são apresentados na Tabela 25. As diferenças entre os tratamentos não foram significativas $(p>0,05)$.

Tabela 25 : Efeito de níveis de PB e EB sobre os coeficientes de digestibilidade aparente de proteína bruta $(\mathrm{PB})$ em rações para capivaras em crescimento (\%).

Níveis de Energia Bruta Médias dos Níveis de Proteína Bruta

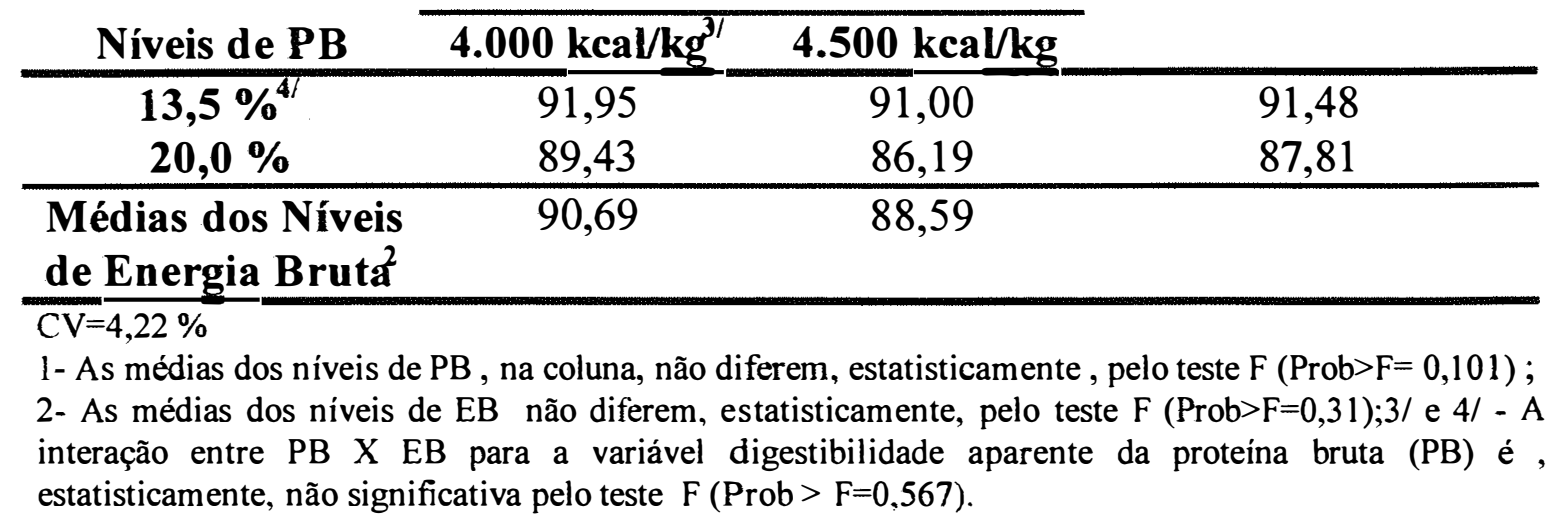

Embora, não tenham ocorrido diferenças significativas entre os tratamentos, verificou-se que existe uma tendência dos tratamentos com maior 
nível energético e daqueles com maior nível protéico em apresentar menor CDPB. Segundo Maynard \& Loosli (1966), à medida que aumenta o nível protéico de uma dieta o CDPB tende a diminuir, isto porque sendo o nitrogênio metabólico regulado pela ingestão total de alimentos, ele tende a permanecer constante embora a ingestão protéica aumente. Dessa forma o nitrogênio endógeno fecal não aumenta proporcionalmente à ingestão protéica. A digestibilidade aparente da proteína, então, diminui, mesmo que seu valor real não se altere significativamente.

Ojasti (1971) estimou em 64,5, 68,8 e 63,0\% os coeficientes de digestibilidade aparente de proteína bruta (CDPB) de Paspalum fasciculatum, Brachiaria mutica e Echinochloa polystachya em capivaras. González-Jiménez \& Parra (1972) encontraram um CDPB médio de 68,65\% para capivaras alimentadas com Brachiaria mutica .Para capivaras alimentadas com ração contendo diferentes níveis de volumoso $(15,22,29,36$ e $43 \%)$, Bernardi (1993) determinou um coeficiente médio de digestibilidade aparente da proteína bruta de 71,51 $\pm 6,46 \%$. González-Jiménez \& Escobar (1975) estimaram em 76,01 , 46,26 e $16,51 \%$ a digestibilidade do nitrogênio de capivaras alimentadas com dietas contendo concentrado e forragem nas proporções de 100:0, 50:50, 0:100, respectivamente

No presente estudo, o nitrogênio endógeno fecal foi estimado em aproximadamente $7,93 \mathrm{mg}$ de $\mathrm{N} / \mathrm{kg}$ de peso metabólico por dia, através da regressão $\left(r^{2}=0,91\right)$ entre a quantidade de nitrogênio fecal e os níveis protéicos utilizados nas rações : Nitrogênio fecal $(\mathrm{g})=0,050840+0,102423$ X nível de PB. $\mathrm{O}$ nitrogênio endógeno urinário também foi estimado em cerca de $625,60 \mathrm{mg}$ de $\mathrm{N} / \mathrm{kg}$ de peso metabólico por dia, pela regressão $\left(\mathrm{r}^{2}=0,66\right)$ entre a quantidade de nitrogênio da urina e os níveis protéicos utilizados nas rações : $\mathrm{N}$ urinário $=$ 4,01008 - 0,438379 X nível de PB. 
Através das estimativas do nitrogênio endógeno fecal e urinário pode ser realizado o balanço de nitrogênio para cada nível protéico utilizado no experimento. Pela regressão $\left(r^{2}=0,91\right)$ entre o balanço de nitrogênio e o consumo diário de nitrogênio dos animais submetidos a diferentes níveis de $\mathrm{PB}$, foi estimado que, para que capivaras em crescimento (com média de PV de 11,92 $\mathrm{kg}$ ) alimentadas com rações concentradas possam manter em equilíbrio seu balanço de nitrogênio (balanço $=0$ ) são necessárias 490,33 $\mathrm{mg}$ de $\mathrm{N} / \mathrm{kg}$ de peso metabólico ou 3,0106 g de N/dia, ou ainda, 18,82 g de proteína/dia.

O valor obtido é similar ao encontrado por González-Jiménez \& Escobar (1975) para capivaras de cerca de $25 \mathrm{~kg}$ de PV alimentadas com

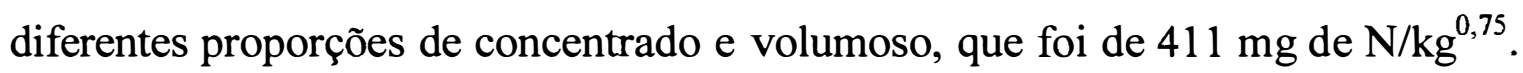
Entretanto, esses autores encontraram valores bem maiores de nitrogênio endógeno fecal, 5,32 g/dia o que, possivelmente, se deva, em parte, ao maior peso e idade dos animais utilizados por eles, bem como a dieta utilizada que, contendo volumoso em sua composição, era mais grosseira do que a ração utilizada no presente estudo, aumentando dessa forma as perdas de nitrogênio endógeno pelas fezes. A Figura 8 mostra a regressão entre o balanço e o consumo diário de nitrogênio. 


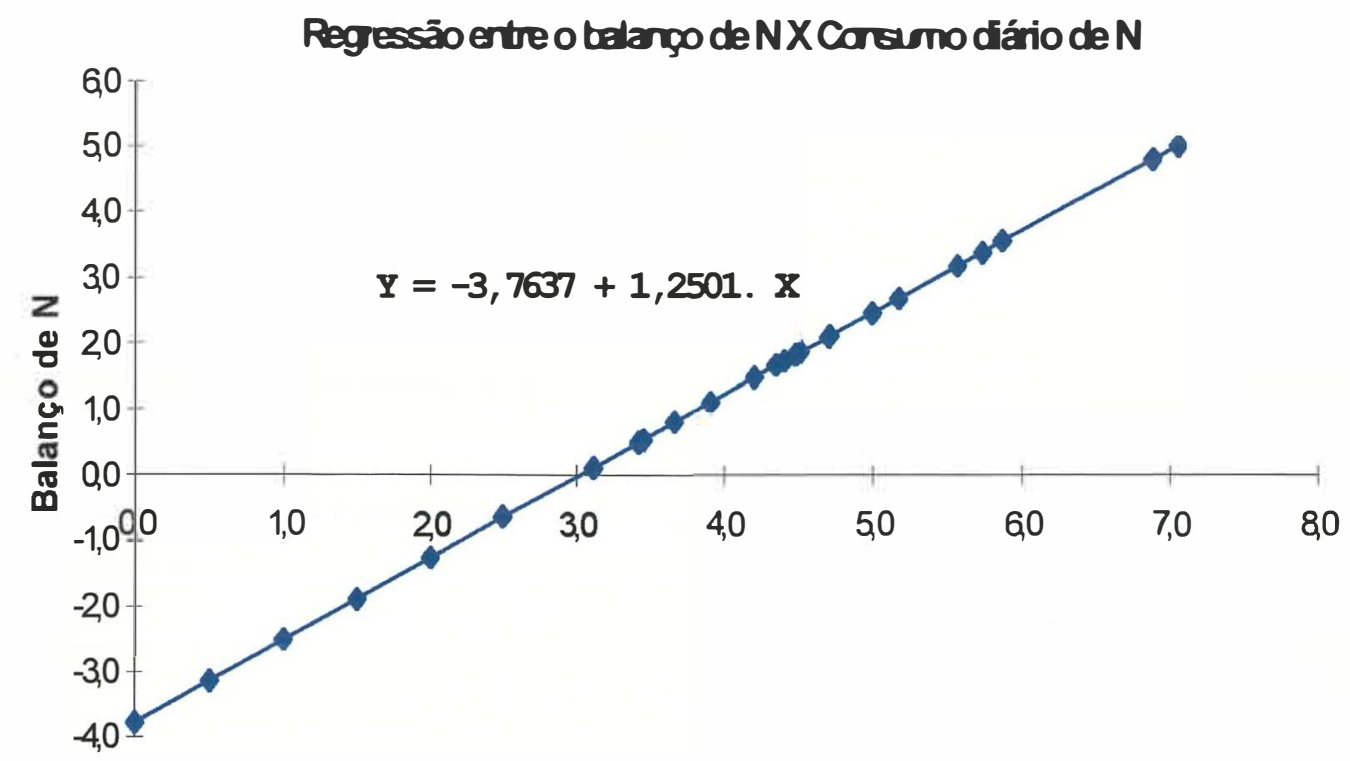

Consumodiáriode $\mathrm{N}(\mathrm{g})$

Figura 8: Regressão entre o consumo diário de nitrogênio e o balanço de nitrogênio para capivaras com $12 \mathrm{~kg}$ de $\mathrm{PV}$ alimentadas com ração concentrada com diferentes níveis de proteína bruta (13,5 e 20,0\%).

A quantidade de $\mathrm{N}$ necessária para o equilíbrio do balanço de nitrogênio é inferior a quantidade de nitrogênio ingerida diariamente pelas capivaras do experimento $(4,7 \pm 1,07 \mathrm{~g}$ de $\mathrm{N} / \mathrm{dia})$. Isto mostra que, como foi mencionado quando da análise de GDP, consumo diário e conversão e eficiência protéica no experimento I-A, para um nível protéico de $20 \%$ de PB, existe um excesso de proteína fornecido ao animal (consumo diário de 5,06 g de $\mathrm{N}$ ) em relação aos que receberam um nível de 13,5\% (consumo diário de 4,73 g de N), sendo que este acaba utilizando esse excesso como fonte de energia. 


\subsubsection{Digestibilidade da energia bruta}

A Tabela 26 apresenta os valores médios dos coeficientes de digestibilidade aparente da energia bruta para os diferentes tratamentos experimentais. Não houve diferenças estatisticamente significativas $(p>0,05)$ entre os tratamentos. Verificou-se uma tendência (prob $>\mathrm{F}=0,099$ ) dos tratamentos que receberam maior nível protéico em apresentarem menores coeficientes de digestibilidade aparente.

Tabela 26 : Efeito de níveis de PB e EB sobre os coeficientes de digestibilidade aparente da energia bruta (EB) em rações para capivaras em crescimento (\%).

\begin{tabular}{|c|c|c|c|}
\hline \multirow[b]{2}{*}{ Níveis de PB } & \multicolumn{2}{|c|}{ Níveis de Energia Bruta } & \multirow{2}{*}{$\begin{array}{l}\text { Médias dos Níveis } \\
\text { de Proteína Bruta }^{1}\end{array}$} \\
\hline & $4.000 \mathrm{kcal} / \mathrm{kg}^{3 /}$ & $4.500 \mathrm{kcal} / \mathrm{kg}$ & \\
\hline $13,5 \%{ }^{4 /}$ & 92,63 & 93,48 & 93,06 \\
\hline $20,0 \%$ & 91,07 & 89,86 & 90,27 \\
\hline $\begin{array}{l}\text { Médias dos Níveis } \\
\text { de Energia Bruta }\end{array}$ & 92,01 & 91,41 & \\
\hline \multicolumn{4}{|c|}{$\begin{array}{l}\mathrm{CV}=1,89 \% \\
1-\text { As médias dos niveis de } \mathrm{PB}, \text { na coluna, não diferem, estatisticamente, pelo teste } \mathrm{F}(\operatorname{Prob}>\mathrm{F}=0,099) \\
\text { 2- As médias dos niveis de } \mathrm{EB} \text { não diferem, estatisticamente, pelo teste } \mathrm{F}(\mathrm{Prob}>\mathrm{F}=0,608) ; 3 / \text { e } 4 /-\mathrm{A} \\
\text { interação entre } \mathrm{PB} X \mathrm{~EB} \text { para a variável digestibilidade da } \mathrm{EB} \text { é , estatisticamente, não significativa pelo } \\
\text { teste } \mathrm{F}(\text { Prob }>\mathrm{F}=0,55) \text {. }\end{array}$} \\
\hline \multicolumn{4}{|c|}{ O coeficiente médio de digestibilidade aparente da energia bruta } \\
\hline
\end{tabular}




\subsubsection{Digestibilidade do extrato etéreo:}

A Tabela 27 apresenta os valores médios de coeficiente de digestibilidade aparente do extrato etéreo (CDEE). Houve diferenças estatísticas significativas $(\mathrm{p}<0,05)$ nos CDEE resultantes dos níveis de proteína bruta e dos níveis de energia bruta utilizados. As interações entre PB e EB também foram altamente sigificativas $(\mathrm{p}<0,01)$. A Tabela 28 apresenta o quadro de análise de variância para o desdobramento das interações entre $\mathrm{PB} X \mathrm{XB}$ e o teste $\mathrm{F}$ para as comparações por contrastes ortogonais.

Tabela 27: Efeito de níveis de PB e EB sobre a digestibilidade de EE em rações para capivaras em crescimento (\%).

\begin{tabular}{|c|c|c|c|}
\hline \multirow[b]{2}{*}{ Níveis de PB } & \multicolumn{2}{|c|}{ Níveis de Energia Bruta } & \multirow{2}{*}{$\begin{array}{l}\text { Médias dos Níveis } \\
\text { de Proteína Bruta }\end{array}$} \\
\hline & $4.000 \mathrm{kcal} / \mathrm{kg}^{3 /}$ & $4.500 \mathrm{kcal} / \mathrm{kg}^{3 /}$ & \\
\hline $\begin{array}{l}13,5 \%{ }^{4 /} \\
20,0 \%\end{array}$ & $\begin{array}{l}51,34^{b} \\
56,12^{b}\end{array}$ & $\begin{array}{l}77,26^{\mathrm{a}} \\
49,52^{\mathrm{b}}\end{array}$ & $\begin{array}{l}64,30^{\mathrm{a}} \\
52,82^{\mathrm{b}}\end{array}$ \\
\hline $\begin{array}{l}\text { Médias dos Níveis } \\
\text { de Energia Bruta }^{2}\end{array}$ & $53,73^{b}$ & $63,39^{\mathrm{a}}$ & \\
\hline \multicolumn{4}{|c|}{$\begin{array}{l}\mathrm{CV}=13,41 \% \\
1-\mathrm{Na} \text { coluna, as médias dos níveis de } \mathrm{PB} \text { seguidas de mesma letra não diferem, estatisticamente, pelo } \\
\text { teste } \mathrm{F} \text { (Prob }>\mathrm{F}=0,026) ; 2-\text { As médias dos niveis de } \mathrm{EB} \text { seguidas de mesma letra não diferem, } \\
\text { estatisticamente, pelo teste } \mathrm{F} \text { (Prob }>\mathrm{F}=0,049) ; 3 / \text { - Nas colunas, as médias de níveis de } \mathrm{PB} \text { dentro de } \mathrm{EB} \\
\text { seguidas de mesma letra não diferem, estatisticamente, ao nível de } 1 \% \text { de probabilidade pelo teste } \mathrm{F} ; 4 / \text { - } \\
\text { Médias de níveis de EB dentro de } \mathrm{PB} \text { seguidas de mesma letra não diferem, estatisticamente, ao nivel de } \\
1 \% \text { de probabilidade pelo teste } \mathrm{F} \text {. }\end{array}$} \\
\hline
\end{tabular}


Tabela 28: Quadro de análise de variância do efeito interação entre níveis de PB e EB, dentro de cada fator (contraste), na digestibilidade de EE em rações para capivaras em crescimento.

\begin{tabular}{lrrrrr}
\hline Causas de Variação & G.L & $\begin{array}{c}\text { Soma de } \\
\text { Quadrados }\end{array}$ & $\begin{array}{c}\text { Quadrado } \\
\text { Médio }\end{array}$ & F & $\begin{array}{c}\text { Prob > } \\
\text { F }\end{array}$ \\
\hline Níveis de Energia & 1 & 373,65 & 373,65 & 6,06 & 0,049 \\
- Níveis de proteína dentro & 1 & 45,65 & 45,65 & 0,74 & 0,42 \\
$\quad$ da EB=4.000 kcal/kg & & & & & \\
- Níveis de proteína dentro & 1 & 1538,74 & 1538,74 & 24,96 & 0,002 \\
$\quad \begin{array}{l}\text { da EB=4.500 kcal/kg } \\
\text { Níveis de Proteína }\end{array}$ & 1 & 527,16 & 527,16 & 8,55 & 0,026 \\
- Níveis de energia dentro & 1 & 1343,95 & 1343,95 & 21,80 & 0,003 \\
$\begin{array}{l}\text { da PB=13,5\% } \\
\text { - Níveis de energia dentro } \\
\text { da PB=20,0\% }\end{array}$ & 1 & 86,92 & 86,92 & 1,41 & 0,28 \\
\hline
\end{tabular}

Os tratamentos que receberam maior nível de proteína tiveram menor coeficiente de digestibilidade aparente do extrato etéreo (CDEE). Os tratamentos que receberam mais energia tiveram maior $\mathrm{CDEE}$, o que se deve, provavelmente, não a uma maior digestibilidade real mas sim por uma maior ingestão de gordura a que os animais foram submetidos nesses tratamentos. A interação entre o maior nível protéico e o maior nível de energia dos tratamentos foi estatisticamente significativa $(p<0,01)$ e proporcionou o menor CDEE, indicando um forte efeito de elevados níveis de proteína sobre o CDEE. Quando se manteve o nível protéico mais baixo ao se aumentar o nível energético, houve um incremento significativo $(\mathrm{p}<0,01)$ da digestibilidade aparente de extrato etéreo, sendo o contrário do observado no nível mais elevado de proteína.

Capivaras alimentadas com Paspalum fasciculatum apresentaram um coeficiente de digestibilidade aparente do extrato etéreo (CDEE) de 9,7\%(Ojasti, 1973). Em animais alimentados com Brachiaria mutica, González- 
Jiménez \& Parra (1972) estimaram um CDEE médio de 56,05\%. O coeficiente médio de digestibilidade aparente do EE encontrado por Bernardi (1993) para capivaras recebendo rações com níveis crescentes de volumoso foi de $80,60 \pm 4,83 \%$.

\subsubsection{Digestibilidade da fibra bruta}

Os coeficientes médios de digestibilidade da fibra bruta (CDFB) são apresentados na Tabela 29. Não houve diferenças estatísticas significativas $(p>0,05)$ entre os tratamentos. Foi verificada uma forte tendência ( $p r o b>F=0,099$ ) dos tratamentos que receberam maior nível protéico em apresentar menor CDFB. Existe também uma tendência dos tratamentos com maior nível energético em apresentarem menor CDFB.

Tabela 29 : Efeito de níveis de PB e EB sobre a digestibilidade de FB em rações para capivaras em crescimento (\%).

\begin{tabular}{|c|c|c|c|}
\hline \multirow[b]{2}{*}{ Níveis de PB } & \multicolumn{2}{|c|}{ Níveis de Energia Bruta } & \multirow{2}{*}{$\begin{array}{l}\text { Médias dos Níveis } \\
\text { de Proteína Bruta }\end{array}$} \\
\hline & $4.000 \mathrm{kcal} / \mathrm{kg}^{3 /}$ & $4.500 \mathrm{kcal} / \mathrm{kg}$ & \\
\hline $13,5 \%$ & 76,16 & 72,38 & 74,27 \\
\hline $20,0 \%$ & 71,77 & 56,54 & 64,16 \\
\hline $\begin{array}{l}\text { Médias dos Níveis } \\
\text { de Energia Bruta }\end{array}$ & 73,97 & 64,46 & \\
\hline $\begin{array}{l}\mathrm{CV}=19,40 \% \\
1-\text { As médias dos níveis } \\
\text {;2- As médias dos níveis } \\
\text { interação entre } \mathrm{PB} X \text { par }\end{array}$ & $\begin{array}{l}\text { B , na coluna, não } \\
\text { EB não diferem, es }\end{array}$ & $\begin{array}{l}\text { n, estatisticament } \\
\text { camente, pelo tes } \\
\text { da FB é, estatist }\end{array}$ & $\begin{array}{l}\text { pelo teste } F(\text { Prob }>F=0,099 \\
\text { (Prob }>F=0,162) ; 3 / \text { e } 4 /- \\
\text { nente, não significativa pelc }\end{array}$ \\
\hline
\end{tabular}

Ojasti (1971) determinou coeficientes de digestibilidade da fibra bruta (CDFB) de 60,5 e 52,1 \% para capivaras alimentadas com Brachiaria 
mutica e Echinochloa polystachya, respectivamente.González-Jiménez \& Parra (1972) observaram um CDFB de 60,25 \% em capivaras alimentadas com Brachiaria mutica. Ojasti (1973) determinou em cerca de 54,5\% o CDFB para capivaras alimentadas com Paspalum fasciculatum. Baldizan et al. (1982) estudando o efeito da adição de farinha de mandioca (0, 15 e 30\%) à dieta de feno de Cenchrus ciliaris sobre a digestibilidade dos nutrientes, encontraram os seguintes coeficientes de digestibilidade da FB, respectivamente : 50,7, 52,9 e $52,0 \%$.

Bernardi (1993) determinou um coeficiente médio de digestibilidade da FB de 50,99 $12,86 \%$ para capivaras de aproximadamente 35 kg de PV alimentadas com rações contendo níveis crescentes de volumosos.

\subsubsection{Digestibilidade da fibra em detergente neutro (FDN)}

Na Tabela 30 são apresentadas as médias dos coeficientes de digestibilidade de FDN. Houve diferenças significativas $(p<0,05)$ pelo teste $F$ entre os diferentes níveis de $\mathrm{PB}$ e entre os diferentes níveis de $\mathrm{EB}$. As interações entre os níveis de PB X EB não foram significativas ( $p>0,05)$. 
Tabela 30 : Efeito de níveis de PB e EB sobre a digestibilidade de FDN em rações para capivaras em crescimento (\%).

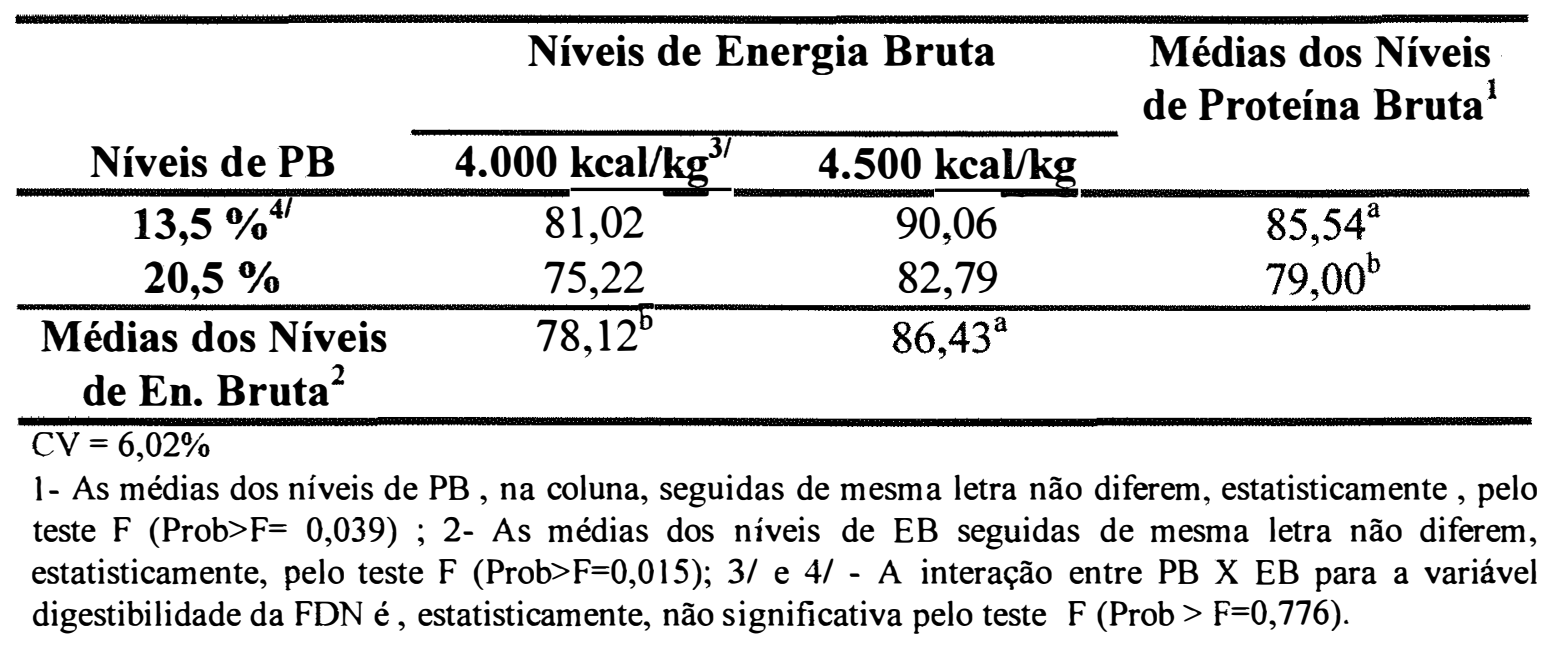

Bernardi (1993) obteve um coeficiente médio de digestibilidade da fibra detergente neutro de $53,18 \pm 9,17 \%$ para animais que receberam rações com níveis crescentes de volumoso (15, 22, 29, 36 e $43 \%)$.

\subsubsection{Digestibilidade da fibra em detergente ácido (FDA)}

As médias dos coeficientes de digestibilidade de FDA são apresentadas na Tabela 31 . Não houve diferenças significativas $(p>0,05)$ entre os tratamentos. Os tratamentos com maior nível protéico apresentaram forte tendência ( $\mathrm{prob}>\mathrm{F}=0,064)$ a apresentarem menores coeficientes de digestibilidade de FDA. 
Tabela 31 : Efeito de níveis de PB e EB sobre a digestibilidade de FDA em rações para capivaras em crescimento (\%).

\begin{tabular}{|c|c|c|c|}
\hline \multirow[b]{2}{*}{ Níveis de PB } & \multicolumn{2}{|c|}{ Níveis de Energia Bruta } & \multirow{2}{*}{$\begin{array}{l}\text { Médias dos Níveis } \\
\text { de Proteína Bruta }\end{array}$} \\
\hline & $4.000 \mathrm{kcal} / \mathrm{kg}^{3 /}$ & $4.500 \mathrm{kcal} / \mathrm{kg}$ & \\
\hline $13,5 \%$ & 77,27 & 79,03 & 78,15 \\
\hline $20,0 \%$ & 71,02 & 63,41 & 67,21 \\
\hline $\begin{array}{l}\text { Médias dos Níveis } \\
\text { de Energia Bruta }\end{array}$ & 74,14 & 71,22 & \\
\hline $\begin{array}{l}\mathrm{CV}=17,40 \% \\
1-\text { As médias dos níveis de } \\
\text { 2- As médias dos níveis d }\end{array}$ & $\begin{array}{l}B \text {, na coluna, não } \\
\text { EB não diferem, }\end{array}$ & $\begin{array}{l}\text { m, estatisticament } \\
\text { ticamente, pelo tes } \\
\text { tibilidade da FDA }\end{array}$ & $\begin{array}{l}\text { pelo teste } F(\text { Prob }>F=0,06 \\
\text { (Prob }>F=0,808) ; 3 / \text { e } 4 / \\
\text { oram, estatisticamente, }\end{array}$ \\
\hline
\end{tabular}

Capivaras submetidas a dietas com níveis crescentes de volumoso (15 a 43\%) apresentaram um coeficiente médio de digestibilidade da fibra em detergente ácido de 43,78 $\pm 16,18 \%$ (Bernardi, 1993).

\subsubsection{Digestibilidade do extrativo não-nitrogenado (ENN)}

A tabela 32 apresenta as médias dos coeficientes de digestibilidade aparente de ENN (CDENN). Houve diferenças estatisticamente significativas $(\mathrm{p}<0,05)$ entre os coeficientes devido aos níveis de proteína. Não foram detectadas diferenças significativas $(p>0,05)$ entre os coeficientes de digestibilidade dos níveis de EB, nem entre a interação de PB X EB. Verificouse forte tendência dos tratamentos mais energéticos em apresentarem menores CDENN. 
Tabela 32 : Efeito de níveis de PB e EB sobre os coeficientes de digestibilidade aparente do extrativo não-nitrogenado em rações para capivaras em crescimento (\%).

\begin{tabular}{cccc}
\hline & \multicolumn{2}{c}{ Níveis de Energia Bruta } & $\begin{array}{c}\text { Médias dos Níveis } \\
\text { de Proteína Bruta }\end{array}$ \\
\cline { 2 - 3 } Níveis de PB & $\mathbf{4 . 0 0 0 ~} \mathbf{k c a l} / \mathbf{k g}^{\mathbf{3}}$ & $\mathbf{4 . 5 0 0} \mathbf{~ k c a l / \mathbf { k g }}$ & \\
\hline $\mathbf{1 3 , 5} \mathbf{\%}^{\mathbf{4}}$ & 96,58 & 97,30 & $96,94^{\mathrm{a}}$ \\
$\mathbf{2 0 , 0} \%$ & 94,99 & 95,39 & $95,19^{\mathrm{b}}$ \\
\hline $\begin{array}{c}\text { Médias dos Níveis } \\
\text { de Energia Bruta }\end{array}$ & 95,78 & 96,34 & \\
\hline
\end{tabular}

$\mathrm{CV}=1,23 \%$

1- As médias dos níveis de PB, na coluna, seguidas de mesma letra não diferem, estatisticamente, pelo teste $F($ Prob $>F=0,02) ; 2-$ As médias dos niveis de $E B$ não diferem, estatisticamente, pelo teste $F$ (Prob $>F=0,37) ; 3 /$ e $4 /$ - As interações entre $\mathrm{PB} X$ EB para a variável digestibilidade aparente da matéria seca (MS) foram, estatisticamente, não significativas pelo teste $F$ (Prob $>F=0,79$ ).

Para capivaras alimentadas com Paspalum fasciculatum, Ojasti (1973) determinou um coeficiente de digestibilidade aparente do extrativo nãonitrogenado (ENN) de 50,9 \%.A média do coeficiente de digestibilidade aparente do ENN obtida por Bernardi (1993), para capivaras que consumiram rações com níveis crescentes de volumosos, foi de $75,48 \pm 3,33 \%$.

\subsubsection{Considerações gerais sobre o ensaio de digestibilidade:}

Os coeficientes de digestibilidade de matéria seca, matéria orgânica, proteína bruta, energia bruta, extrato étereo, fibra bruta, fibra em detergente neutro e fibra em detergente ácido e extrativo não nitrogenado foram, em geral, afetados pelo maior nível de proteína (20\% de PB) e pelo maior nível de energia (4.500 kcal de $\mathrm{EB} / \mathrm{kg})$. 
Houve uma tendência de rações com maior nível energético apresentarem menores coeficientes de digestibilidade dos nutrientes. Essa redução foi, possivelmente, proporcionada por um aumento na taxa de passagem, devido ao maior teor de gordura das rações com $4.500 \mathrm{kcal}$ de EB/ $\mathrm{kg}$. A digestibilidade pode ser limitada pelo tempo necessário para uma ação digestiva completa sobre as substâncias menos digestíveis ou por não haver completa assimilação (Maynard \& Loosli, 1966). Logo, é provável que, os animais que receberam rações com $4.500 \mathrm{kcal}$ de EB/kg no experimento I, parte A, apresentaram pior desempenho não só por terem ingerido menos nutrientes (menor consumo) mas, também, por não tê-los digerido mais eficientemente .

Os animais que receberam rações com maior nível protéico (20\% de $\mathrm{PB}$ ) tenderam a apresentar menores coeficientes de digestibilidade dos nutrientes. Cheeke (1987) relata que o excesso de proteína em rações para coelhos leva a um aumento da quantidade de nitrogênio (na forma de íon amônio, $\mathrm{NH}_{4}{ }^{+}$) no ceco. Esses elevados níveis de amônia aumentam o pH cecal , tornando o ambiente propício à proliferação de bactérias como as do gêneros Escherichia $\mathrm{e}$ Clostridia. Para capivaras, essa modificação do ambiente cecal, devido a uma maior quantidade de nitrogênio, pode ter ocasionado a redução nos coeficientes de digestibilidade.

Segundo Morrison (1948), suínos alimentados com ração contendo $42 \%$ de $\mathrm{PB}$, durante 13 semanas, permaneceram saudáveis e mantiveram um crescimento normal. Entretanto, essa ração com excesso de proteína apresentou um efeito laxante. Esse efeito laxante, proporcionando uma maior taxa de passagem, pode afetar, consideravelmente, a digestibilidade dos nutrientes. 
Uma maior ingestão protéica é acompanhada por um maior consumo de água (Cheeke, 1987). Uma maior quantidade de água ingerida pode prejudicar o processo digestivo do bolo alimentar.

Os coeficientes de digestibilidade de PB, EB, FB, FDN, FDA e ENN obtidos no presente experimento foram superiores aos encontrados na literatura, o que foi devido, provavelmente, ao reduzido percentual de fibra bruta $(3,29 \%)$ das rações experimentais. 


\section{CONCLUSÕES}

Os resultados obtidos, nas condições em que este trabalho foi realizado, levaram às seguintes conclusões:

1 ) Não houve diferenças significativas em GDP, consumo diário, peso vivo aos 8 meses de idade para capivaras em crescimento alimentadas com rações com níveis de PB de 13,5 e 20\% e níveis de EB de 4.000 e $4.500 \mathrm{kcal} / \mathrm{kg}$.

2) Foram detectadas diferenças $(p<0,05)$ entre os tratamentos para conversão alimentar. Os animais que receberam dietas contendo um nível de EB de 4.000 $\mathrm{kcal} / \mathrm{kg}$ e um nível de PB de $20 \%$ tenderam a apresentar um maior desenvolvimento corporal e um maior GDP e tiveram melhor conversão alimentar. Para o nível energético de $4.000 \mathrm{kcal}$ de $\mathrm{EB} / \mathrm{kg}$, o nível protéico ótimo para proporcionar maiores ganhos de peso e maior eficiência protéica deve ser um valor intermediário entre os níveis $13,5 \%$ e $20 \%$ de PB.

3 ) Animais que receberam dietas com $4.500 \mathrm{kcal} / \mathrm{kg}$ apresentaram um desempenho inferior aos tratamentos com nível de $4.000 \mathrm{kcal}$ de $\mathrm{EB} / \mathrm{kg}$, devido a uma menor ingestão de MS. O ajuste do nível de proteína bruta a esse maior nível energético deverá proporcionar melhores resultados. Assim como foi observado para o nível de $4.000 \mathrm{kcal}$ de $\mathrm{EB} / \mathrm{kg}$, um nível protéico de $20 \%$ de $\mathrm{PB}$ 
representa um excesso de ingestão protéica, sendo esse excesso utilizado como fonte de energia.

4 ) As capivaras que receberam maior nível energético tiveram menores taxas de incidência de doenças e menores taxas de mortalidade, sendo recomendável utilizar para capivaras em crescimento, principalmente, no caso de animais submetidos a uma maior carga de estresse, maiores níveis energéticos (maior ou igual a $4.500 \mathrm{kcal}$ de $\mathrm{EB} / \mathrm{kg}$ ) e um nível de proteína bruta, intermediário entre 13,5 e $20 \%$ de $\mathrm{PB}$ e ajustado a esse maior nível energético, para que haja um melhor desempenho do animal com uma maior eficiência protéica e uma maior resistência ao estresse e às doenças.

5 ) Não existiram diferenças significativas para peso de carcaça quente, rendimento de carcaça, rendimento de came, peso do couro, rendimento de pernil, rendimento de lombo e área de olho de lombo, entre os tratamentos. Os animais que foram alimentados com maior nível de proteína bruta (20\%) apresentaram maior teor de gordura corporal (mais intramuscular do que subcutânea).O maior nível protéico acompanhado do maior nível energético resultou em maiores valores de rendimento de carne e de teor de gordura na carcaça.

6 ) Entre animais confinados $\left(1\right.$ cabeça/20 $\left.\mathrm{m}^{2}\right)$ e animais semiconfinados (1 cabeça/ $70 \mathrm{~m}^{2}$ ), as diferenças estatísticas não foram significativas para GDP. Animais confinados tiveram menor consumo e melhor conversão alimentar do que animais semiconfinados. Animais que receberam ração concentrada semiconfinados não diferiram em GDP, consumo de MS e conversão alimentar daqueles que foram confinados e receberam o mesmo tipo de dieta. 
7 ) Capivaras em crescimento confinadas e semiconfinadas apresentaram uma taxa de mortalidade de $20 \%$ e $0 \%$,respectivamente. Isto deveu-se à maior carga de estresse e manejo a qual os animais confinados estavam submetidos

8 ) Animais confinados alimentados apenas com capim elefante (G2) apresentaram um desempenho bastante inferior (menor GDP e pior conversão alimentar) e um aspecto geral de debilidade física. Não houve diferenças estatísticas significativas para GDP entre os animais que consumiram apenas ração concentrada peletizada (confinados, G1, e semiconfinados, G3) e aqueles que receberam capim elefante suplementado por ração farelada (semiconfinados, G4). Os animais de G4 apresentaram maior consumo e pior conversão alimentar do que os de Gl.

9 ) Capivaras em crescimento criadas confinadas e alimentadas com ração concentrada peletizada apresentaram um maior teor de gordura corporal e uma tendência a um maior rendimento de paleta e costela. Animais semiconfinados que receberam ração farelada e capim elefante tenderam a apresentar menor rendimento de carcaça, maior rendimento de pernil e um menor teor de gordura.

10 ) Não foram encontradas diferenças significativas para GDP e conversão alimentar entre animais que foram confinados e começaram a receber ração em diferentes idades (70 e 150 dias). Capivaras que começaram a receber ração aos 70 dias de idade apresentaram maior consumo e maior taxa de mortalidade.

11 ) Os coeficientes de digestibilidade de matéria seca, matéria orgânica, proteína bruta, energia bruta, extrato étereo, fibra bruta, fibra em detergente neutro e fibra em detergente ácido e extrativo não nitrogenado foram menores para rações com 
maior nível de proteína (20\% de PB) e com maior nível de energia (4.500 kcal de $\mathrm{EB} / \mathrm{kg})$. O reduzido percentual de fibra bruta $(3,29 \%)$ das rações experimentais proporcionou maiores coeficientes de digestibilidade dos nutrientes do que os encontrados para capivaras na literatura. 


\section{REFERÊNCIAS BIBLIOGRÁFICAS}

AJAYI, S.S. La ordenación sostenible de los recursos silvestres : el caso de Africa. In: FAO. Sistemas de realización de la ordenación florestal sostenible. Roma: FAO, 1995. p.87-107. (Série Estudio FAO Montes, 122).

ALBUQUERQUE, N.I. Ganho de peso em capivaras (Hydrochoerus hydrochaeris hydrochaeris L. 1766) na fase final de crescimento em 3 categorias: machos inteiros, machos castrados e fêmeas. Piracicaba, 1993. 65 p. Dissertação (Mestrado) - Escola Superior de Agricultura "Luiz de Queiroz”, Universidade de São Paulo.

ALFINITO, J. Recursos da fauna. Bélem: CEPA, 1978. 25 p.

ALHO, C.J.R. Brazilian rodents : their habitats and habits. Pymatuning Laboratory of Ecology, 6, Special Publication Series. University of Pittsburgh, 1982. Vol. 6.

ALHO, C.J.R. Capivaras, uma vida em família. Ciência Hoje, v.4, n.23, p.6468, mar./abr.1986. 
ALHO, C.J.R.; CAMPOS, Z.M.S.; GONÇALVES, H.C. Ecologia de capivara (Hydrochaeris hydrochaeris, Rodentia) do Pantanal : - I - Habitats, densidades e tamanho do grupo. Revista Brasileira de Biologia, v. 47, n. 1/2, p. 87-97, fev./maio de 1987.

ALLEN, M. E. \& ULLREY, D.E. Identification of nutritional problems in captive wild animals. In: FOWLER, M.E. Zoo \& wild animal medicine. 3ed. W.B. Saunders Company, 1992. cap. 9, p.38-41.

ANDRADE, P.C.M.; ELIAS, A.M.; CARVALHO, A. de; LAVORENTI, A.; NOGUEIRA FILHO, S.L.G. Curva de crescimento de capivaras (Hydrochoerus hydrochaeris hydrochaeris) em cativeiro. In: REUNIÃO ANUAL DA SOCIEDADE BRASILEIRA PARA O PROGRESSO DA CIÊNCIA, 48., São Paulo, 1996. Anais. São Paulo: PUC/SBPC/CNPq, 1996. p. 75.

ANDRIGUETTO, J.M.; PERLY, L.;MINARDI, I.; GEMAEL, A. FLEMMING, J.S.; SOUZA, G.A. ;BONA FILHO, A. Nutrição animal : as bases e os fundamentos da nutrição animal. 4. ed. São Paulo : Nobel , 1990. v. 1, 395 p.

ANUÁRIO ESTATÍSTICO DO BRASIL, 1965-70. Rio de Janeiro : Fundação IBGE, 1965-70. v.26-28, v. 30-31.

ASSAF, A.; CRUZ, O. Estudios sobre la industrialización de la came de chiguire. In:Informe del CIEPE ( $1^{\underline{a}}$ fase) al CONICIT. Maracay: IPA/Un.Central de Venezuela, 1976. 42 p. 
ASSAF, A.; CRUZ, O.M.; AGUERO, A.; GONZÁLEZ-JIMÉNEZ, E. Estudio sobre la capacidad de retención de água y poder de emulsificación de carne de chigüire con relación a la de res, cerdo y pollo. In: SEMINARIO SOBRE CHIGUIRE Y BABAS, 2. , Maracay, 1976. Programas y resumenes . Maracay, Venezuela: Facultad de Agronomia/CONICIT/IPA,. 1976. p.78-80.

\section{ASSOCIATION OF OFFICIAL AGRICULTURAL CHEMISTS. Official} methods of analysis. 11. ed. Washington : Association of Official Agricultural Chemists, 1980.

AYRES, J.M. \& BEST, R. Estratégias para a conservação da fauna amazônica. Acta Amazônica, v. 9., n. 4, p. 81-101, 1979. Suplemento.

AZCÁRATE , T.B. Sociobiologia del Chigüire (Hydrochoerus hydrochaeris). Madrid, 1976. 154 p. Tese (Doutorado) - Universidad Complutense de Madrid.

AZCÁRATE, T.B. Algunos datos sobre el comportamiento social en una manada de chigüires (Hydrochoerus hydrochaeris). In: SEMINARIO SOBRE CHIGUIRE Y BABAS, 2., Maracay, 1976. Programas y resumenes. Maracay, Venezuela: Facultad de Agronomia/CONICIT/IPA,. 1978. p.13-15.

AZCÁRATE , T.B.; BRAZA, F.; ALVARES, F. Observaciones sobre la reproducción del capibara (Hydrochoerus hydrochaeris) en los llanos de Venezuela. Doñana Acta Vertebrata, v.6, n.2, p. 244-247, 1979.

BALDIZÁN, A.; DIXON, R.M.; PARRA, O. de; PARRA, R. Efecto de la adicion de harina de yuca a una dieta de heno (Cenchrus ciliaris) sobre la digestibilidad de la materia seca y pared celular en ovejas y chiguire. Informe Anual IPA, Maracay, Venezuela. p. 27-28, 1982. 
BALDIZÁN, A. ; DIXON, R.M.; PARRA, R. Digestion in the capybara (Hydrochoerus hydrochaeris). South Africa Journal Animal Science, v.13, n.1, p. 27-28, 1983.

BALDIZÁN, A,; DIXON, R.M.; PARRA, R. Características de la fermentación en el tracto gastrointestinal del chigüire (Hydrochoerus hydrochaeris). Informe Anual -IPA, Maracay, Venezuela, p. 60-61. 1986.

BARBELA, L.S. Caracterización preliminar de la gestación en chigüire. Informe Anual IPA, Maracay, Venezuela, p.18-19, 1981.

BARBELA, L.S. Una contribuición al conocimiento de la reproducción del chigüire. Informe Anual IPA, Maracay, Venezuela, p. 109-11 7, 1984.

BARBELA, L.S. Pubertad en hembras chigüires (Hydrochoerus hydrochaeris). Revista de la Facultad de Agronomia de Maracay, v.19, n.2, p.121-127, 1993.

BENCHIMOL, S. Exportação e exportadores da Amazônia Legal. Manaus: Universidade do Amazonas/SEBRAE, 1994. 80 p.

BERNARDI, L.G. Efeito de níveis crescentes de volumoso sobre a digestibilidade de nutrientes de rações para capivaras (Hydrochoerus hydrochaeris hydrochaeris, L. 1766). Piracicaba, 1993. 203 p. Dissertação (Mestrado) - Escola Superior de Agricultura "Luiz de Queiroz", Universidade de São Paulo.

BLOOD, D.C. ; HENDERSON, J.A.; RADOSTITS, O.M. Clínica veterinária. 5. ed. Rio de Janeiro: Guanabara Koogan, 1979. p:854-855: Enfermidades causadas por deficiências nutricionais. 
CABRERA, A. Catálogo de mamíferos de América del Sur, II. Revista del Museu Argentino de Ciencias Naturales Bernardino Ridavia, v.4, n.2, p.309-732, 1960.

CAMPOS, J. Tabelas para cálculo de rações. 2.ed. Viçosa: Universidade Federal de Viçosa, 1981. $65 \mathrm{p}$.

CARVALHO, J.C. A conservação da natureza e recursos naturais na Amazônia Brasileira. Atas Simp. Biota Amazônica, n.7, p. 1-47, 1967.

CATROXO,M.H.B.;MIRANDA,L.B.;LAVORENTI,A.;CAPPELLARO,C.E.M.

P.D.M.; MUELLER, S.B.K. Determinação morfológica de partículas semelhantes a coronavírus associado a um surto de diarréia em capivaras (Hydrochoerus hydrochaeris L.). Arquivos do Instituto Biológico, v.62, p.35, nov./1995. Suplemento.

CHEEKE,P.R. Rabbit feeding and nutrition : animal feeding and nutrition. Orlando: Academic Press, 1987. cap. 20, p.354-357: Nutrition of the Capybara.

CLARK, J.D.; LOEW, F.M.; OLFERT, E.D. Rodents (Rodentia). In: FOWLER, M.E. Zoo \& wild animal medicine. 2. ed. W.B. Saunders, 1990. cap.21, p.456-478.

CONWAY, W.G. Species in peril. In: Britannica yearbook of science and the future. Chicago: Encycl. Britannica, 1973. p.10-29.

DOUROJEANNI, M.J. Over-exploited and under-used animals in the Amazon Region. In:PRANCE, G.T.; LONEJOY, T.E. (Ed.). Keys environments Amazonia. Oxford: Perga, 1985. p. 419-433. 
ESCOBAR, A. Diagnóstico técnico economico de la explotación comercial comercial del Chigüire (Hydrochoerus hydrochaeris). In: Informe al Proyecto CONICIT, DF 030-S1. Maracay: IPA,Un. Central de Venezuela, 1973.

ESCOBAR, A.; GONZÁLEZ-JIMÉNEZ, E. Variación estacional de la frecuencia relativa de las espécies vegetales consumidas por los chigüires en el llano inundable. Acta Cientifica Venezoelana, vol.25, supl.1, p. 1, 1974.

FAO. Informe del taller sobre las estratégicas para el manejo y el aprovechamiento racional de capibaras, cayman y tortugas de agua dulce (São Paulo, Brasil). Santiago: Oficina Regional de la FAO para Am. Latina Y el Caribe, 1987. $49 \mathrm{p}$.

FRASSON, C.; SALGADO, J.M. Animais silvestres: capivara - uma opção contra a fome e a deficiência em proteína animal. In: SIMPÓSIO INTERFACE NUTRIÇÃO X AGRICULTURA, 2., Piracicaba, 1990. Anais. Piracicaba: FEALQ, 1990. p. 175-200.

FUERBRINGER, J. El Chigüire, su cria y explotación racional. Temas de Orientación Agropecuária, Bogotá, n. 99, p.1 -59, 1974.

GEDEK, B.R.; FLACHOWSKY, G.; SCHUBERT, R. Probiotics as bioregulators. Vitamine und Weitere Zusatzstoffe bei Mensch und Tier, 4 Symposium, p.253-262, 1993. /Resumo em CAB Abstrats on CD-ROM, 1993-94/ .

GODOY,J.F.; GÓMEZ, E.A.A. Industrialización de la came de chigüire. In: SEMINARIO SOBRE CHIGUIRE Y BABAS, 2., Maracay, 1976. Programas y resumenes. Maracay, Venezuela: Facultad de Agronomia/CONICIT/IPA,. 1976. p.81-82. 
GOERING, H.K. \& VAN SOEST, P.J. Forage fiber analyses: apparatus, reagents, procedures and some aplications. Washington : USDA, Agricultural Research Service, 1970. 379 p. (USDA, ARS., Agriculture Handbook)

GONZÁLEZ-JIMÉNEZ, E. Digestive physiology and feeding of capybaras. In: RECHCIGE, M. (Ed.). Handbook series in nutrition and food. Cleveland: CRC Press, 1977. p. 163-177. (Série G, Diets for mammals, v. 1).

GONZÁLEZ-JIMÉNEZ, E. The capybara: An indigenous source of meat in tropical America. World Animal Revue, n. 21, p. 24-30, 1978.

GONZÁLEZ-JIMÉNEZ, E. El capibara (Hydrochoerus hydrochaeris) : estado actual de su producción. Roma: FAO, 1995. 112 p. (Série Estudio FAO, Produccion y Sanidad Animal, 122).

GONZÁLEZ-JIMÉNEZ,E.; ESCOBAR,A. Digestibilidad comparada entre chiguire (Hydrochoerus hydrochaeris), conejos y ovinos con raciones de diferentes proporciones de forrajes y concentrado. Revista Agronomia Tropical, v.25, n.3, p.283-290, maio/jun. 1975.

GONZÁLEZ-JIMÉNEZ,E. \& ESCOBAR,A. Flood adaptation and productivity of savanna grasses. In: INTERNATIONAL GRASSLAND CONGRESS, 13., Berlin, 1977. Proceedings. Berlin : Leipzig Akademic Verlag, 1977. p.510514.

GONZÁLEZ-JÍMENEZ, E.; PARRA, R. Fisiologia digestiva del chigüire. 2. Cinética de los nutrientes en el tracto digestivo. In: Informe al Proyecto CONICIT, DF 030-S1. Maracay: IPA,Un. Central de Venezuela, 1972. 7 p. 
GONZÁLEZ-JIMÉNEZ, E.; PARRA, R. The capybara, a meat-producing animal for the flooded areas of the tropics. In: WORLD CONF. ON ANIMAL PRODUCTION, 3., Austrália, 1973. Conservation and recreation. Melborne, 1973. p.81-86.

GONZÁLEZ-JIMÉNEZ, E.; ESCOBAR, A; CAIRES, O. Un método para detectar coprofagia: resultados en chigüires (Hydrochoerus hydrochaeris). In: SEMINARIO SOBRE CHIGUIRE Y BABAS, 2., Maracay, 1976. Programas y resumenes. Maracay, Venezuela: Facultad de Agronomia/CONICIT/IPA,. 1976. p.25.

HECK, H. Notes on breeding capybara (Hydrochoerus hydrochaeris). Zoologische Gart, v.49, n.1, p. 80, 1979.

HERRERA, E.A. Coprofagy in the capybara (Hydrochoerus hydrochaeris). Journal Zoologic Série A, v.207, n.4, p. 616-619, 1985.

HERRERA, E.A. The effect of harvesting on the age structure and body size of a capybara population. Ecotropicos, Sociedade Venezolana de Ecologia, v.5, n. 1, p. 20-25, 1992.

JORGENSON, J.P. Notes on the ecology and behavior of capybaras in northeastern Colombia. Vida Silvestre Neotropical, v.1, n.1, p.31-40, 1986.

JOSE, D.G.; STUTMAN, O.; GOOD, R.A. Long term effects on immune function of early nutritional deprivation. Nature, v. 248 , n. 5384 , p. 57-58, 1973. /Resumo em CAB Abstracts on CD-ROM, 1972-75/.

LATSHAW, J.D. Nutrition - mechanisms of immunosuppression. Veterinary Immunology and Immunopathology, v.30, n.1, p.11-120, 1991. /Resumo em CAB Abstracts on CD-ROM, 1992/. 
LAVORENTI, A. Domestication and potential for genetic improvement of capybara. Revista Brasileira de Genética, v.12, n.3, p.137-144, 1989.

LAVORENTI,A.; SILVA NETO, P.B.; MARCHI, A.P.; DARI,R.L.; SOUZA, M.C. Desempenho reprodutivo da capivara (Hydrochoerus hydrochaeris hydrochaeris) criada em cativeiro. In: REUNIÃO ANUAL DA SOCIEDADE BRASILEIRA DE ZOOTECNIA, 26., Porto Alegre: SBZ, 1989. Anais. Porto Alegre, 1989. p.271.

LEWIS, L.D. Nutrition for brood mare and growing horse and its role in epiphysitis. Procedure American Association Equus Practice., n. 25, p. 269-296, 1979.

LUSBY, K.S.; STEPHENS, D.F.; TOTUSEK, R. Effects of milk intake by nursing calves on forage intake on range and creep intake and digestibility in drylot. Journal of Animal Science, v. 43, p. 1066-1071, 1976.

McDOWELL, R.E.; SISLER, D.G.; SCHERMERHORN, E.C.; REED, J.D.; BAUER, R.P. Game or cattle for meat production on Kenya rangelands ?. Cornell International Agriculture Mimeograph, n. 101, 77 p., 1983.

MAGALHÃES, A.C. de. Ensaio sobre a fauna brasileira. São Paulo: Secretaria da Agricultura, Indústria e Comércio do Estado de S. Paulo, 1939. $336 \mathrm{p}$.

MARES, M.A.; OJEDA, R.A. Faunal Commercialization and Conservation in South America. BioScience, v.34, n.9, p.580-584, 1984.

MAYNARD, L.A.; LOOSLI, J.K. Nutrição animal. Rio de Janeiro: Livraria Freitas Bastos, 1966. 550 p. 
MEDINA, L.J.L. Contribuición al Estudio Histológico del Tubo Digestivo de Hydrochoerus hydrochaeris hydrochaeris. Maracay, Venezuela, 1980. 65p. Dissertação (Professor Titular) - Faculdade Ciencias Veterinarias / Universidade Central de Venezuela.

MENDES, A. ; NOGUEIRA FILHO, S.; NOGUEIRA, S. ; LAVORENTI, A. Cecotrofagia em capivara (Hydrochoerus hydrochaeris). In: CONGRESSO BRASILEIRO DE ZOOLÓGICOS, 20., Cuiabá, 1996. Anais. Cuiabá : SZB, 1996.

MICHI, K.M.P. Estudo sobre o comportamento social da capivara (Hydrochoerus hydrochaeris) criada em cativeiro. Botucatu, 1993. 100 p. Dissertação (Bacharelado em Ciências Biológicas) - Un. Estadual Paulista.

MILAN, M.A.P. Hábitos nutricionales del chiguiro. Revista del ICA, v.13, n. 4, p.743, 1978.

MONES, A. Estudios sobre la família Hydrochoeridae (Rodentia), I. Introduccion e historia taxonomica. Revista Brasileira de Biologia., v. 33, n. 2, p.277-283, 1973.

MONES, A. Estudios sobre la Família Hydrochoeridae (Rodentia), V. Revalidación de sus caracteres morfologicos dentarios con algunas consideraciones sobre la filogenia del grupo. In: CONGRESO ARGENTINO DE PALEONTOLOGIA Y BIOESTRATIGRAFIA,. 1., Tucumán, 1975. Actas. Tucumán, Argentina: Universidad Nacional de Tucumán y Asociación Paleontológica, 1975. p.463-476.

MONES, A .; OJASTI, J. Hydrochoerus hydrochaeris. In: Mammalian species. The American Society of Mammalogists, 1986. p. 264267. 
MONTES, G. (Ed.). El carpincho. Buenos Aires: Centro Editor de América Latina, 1983. 32 p. (Série Fauna Argentina, 2).

MOREIRA, J.R.; McDONALD, D.W. Simulação do efeito da seleção de sexo no abate de capivaras (Hydrochaeris hydrochoerus) na Ilha de Marajó - Pará. In: REUNIÃO DA SOCIEDADE BRASILEIRA DE ZOOTECNIA, 32., Brasília, 1995. Anais. Brasília: SBZ, 1995. Pequenos animais domésticos e animais silvestres, p. 399-402.

MORRISON, F.B. Feeds and feeding : a handbook for the student and stockman. New York: The Morrison Pub., 1948. 1207 p.

NEGRET, R. Possibilidades do aproveitamento zootécnico da capivara (Hydrochoerus hydrochaeris) na bacia do alto Paraguai, Mato-Grosso. In: Estudo de desenvolvimento integrado da bacia do alto Paraguai. EDIBAE/UNDP/OEA, 1979. 33 p.

NEVILLE, W.E.; McCORMICK, W.C. Performance of early and normalweaned beef calves and their dams. Journal of Animal Science, v. 52, p. 715-724, 1981.

NOGUEIRA FILHO, S.L.G.; NOGUEIRA, S.; CARVALHO, A.; TOMA, R. ; LAVORENTI, A. Estudo da vida reprodutiva em capivaras (Hydrochoerus hydrochaeris) na CIZBAS/ESALQ/USP. In: CONGRESSO BRASILEIRO DE ZOOLÓGICOS, 20., Cuiabá, 1996. Anais. Cuiabá : SZB, 1996.

NOGUEIRA NETO, P. A criação de animais indígenas vertebrados : peixes, anfibios, répteis, aves e mamíferos. São Paulo : Edições Tecnapis, 1973. p.257-273: Ordem Rodentia.

* NOWAK, R..M. Walker's mammals of the world.. 5. ed. London: Johns Hopkins University Press., 1991. v. 2, p.914-916. 
OJASTI, J. Informe sobre la investigación biológica del chiguire. Caracas: MAC, 1971. 299 p.

OJASTI, J. Estudio biológico del chigüire o capibara . Caracas: Fondo Nacional Investigación Agropecuaria., Ed. Sucre, 1973. 275 p.

OJASTI, J. The relation between population and production of the capybara. Georgia, 1978. 284 p. Tese (Ph.D.) - University of Georgia Attens.

OJASTI, J. Human explotation of capybara. In: ROBINSON,J.G; REDFORD, K.H. (Ed.). Neotropical wildlife use and conservation. Chicago: Un. Chicago Press, 1991. cap. 17, p. 236-252.

OJASTI, J.; SOSA BURGOS, L.M. Density regulation in populations of capybara. Acta Zoologica Fennica, n. 173, p.81-83, 1985.

PARRA, R. Información preliminar sobre el crescimiento del chigüire en cautiveiro. In: SEMINARIO SOBRE CHIGUIRE Y BABAS, 2., Maracay, 1976. Programas y resumenes. Maracay, Venezuela: Facultad de Agronomia/CONICIT/IPA,. 1976. p.31-32.

PARRA, R. Comparison of foregut and hingut fermentation in herbivores. In: MONTEGOMERY,G. The ecology of arboreal folivores. Washington : Smithsonian Press, 1978. p.205-229.

PARRA, R.; ESCOBAR,A. Digestibilidad comparada de chiguire y ovinos. In: SEMINARIO SOBRE CHIGUIRE Y BABAS, 2., Maracay, 1976. Programas y resumenes. Maracay, Venezuela: Facultad de Agronomia/CONICIT/IPA,. 1976. p.41-42. 
PARRA, R. ; GONZÁLEZ-JIMÉNEZ, E. Fisiologia digestiva del chiguire (Hydrochoerus hydrochaeris). 1. Capacidad de los diferentes compartimientos del tracto digestivo. In: Informe al Proyecto CONICIT, DF. 030-51. Maracay : IPA, Un.Central de Venezuela, 1971. 14 p.

PARRA, R.; ESCOBAR, A.; GONZÁLEZ-JIMÉNEZ, E. El chigüire, su potencial biológico y su cría en confinamiento. Informe Anual IPA, Maracay, Venezuela, p. 83-94, 1978.

PARRA, R.; ESCOBAR, A.; GONZÁLEZ-JIMÉNEZ, E.; BALDIZÁN, A.; SZABUNIEWICZ, M. Fisiologia digestiva comparada. Informe Anual IPA, Maracay, Venezuela, p. 52-53, 1980.

PRAHARAJ, N.K. ; DUNNINGTON, E.A.; SIEGEL, P.B. Growth, immunoresponsiveness, and disease resistance of diverse of chickens reared under two nutritional regimens. Poultry Science, v. 74, n. 11, p. 1721-1729, 1995.

PICCINI, R.S.; VALE, W.G.; GOMES, F.W.R. Criadouros artificiais de animais silvestres: criadouros de capivaras. Belém: SUDAM-DPRN, 1971. $31 \mathrm{p}$.

REZENDE, A.S.C. de; SAMPAIO, I.B.M.; LEGORRETA, G.L.; MOREIRA, D.C.A.; GONÇALVES, L.C. Avaliação radiográfica de potros Mangalarga Marchador submetidos a dois programas nutricionais diferentes. In: REUNIÃO ANUAL DA SOCIEDADE BRASILEIRA DE ZOOTECNIA, 33., Fortaleza, 1996. Nutrição de não ruminantes: Anais. Fortaleza: SBZ, 1996. v.4, p. 202-204. 
ROSTAGNO, H.S.; SILVA, D.J.; COSTA, P.M.A.; FONSECA, J.B.; SOARES, P.R.; PEREIRA, J.A.A.; SILVA, M.A. Composição de alimentos e exigências nutricionais de aves e suínos (tabelas brasileiras). Viçosa : Un.Federal de Viçosa, 1994. 61 p.

SANTOS, E. Entre o gambá e o macaco: vida e costumes dos mamíferos do Brasil. Belo Horizonte : Itatiaia ., 1984. p. 137-142. (Coleção Zoologia Brasílica, 6).

SILVA NETO, P.B. Alimentação e manejo de capivaras (Hydrochoerus hydrochaeris hydrochaeris L. 1766) em cativeiro. Piracicaba, $1989.81 \mathrm{p}$. Dissertação (Mestrado) - Escola Superior de Agricultura "Luiz de Queiroz", Universidade de São Paulo.

SILVA NETO, P.B. Criação de animais alternativos em cativeiro: vantagens em relação as explorações tradicionais. In: SIMPÓSIO INTERFACE NUTRIÇÃO X AGRICULTURA, 2., Piracicaba, 1990. Anais . Piracicaba: FEALQ, 1990. p. $167-173$.

SILVA NETO, P.B. Criação racional de animais silvestres. Jornal do Fazendeiro, Goiânia, p.5, maio/ 1996.

SILVA NETO, P.B.; LAVORENTI, A.; ALMEIDA, A.F.; De MARCHI, A.P.; FERNANDES, M.B. Parâmetros Reprodutivos da Capivara (Hydrochoerus hydrochaeris hydrochaeris L. 1766) em Cativeiro. In: REUNIÃO ANUAL DA SOCIEDADE BRASILEIRA DE ZOOTECNIA, 27., Campinas, 1990. Anais. Piracicaba: FEALQ, 1990. p.457.

SMITH, N.J.H. Utilization of game along Brazil's transamazon highway. Acta Amazonica, v. 6, p. 455-466, 1976. 
SOUŻA, M.C.; SILVA NETO, P.B.; LAVORENTI, A.; MARCHI, A.P.; MONTEIRO, C.C. Influência dos fatores idade e peso vivo na formação de grupos de capivaras (Hydrochoerus hydrochaeris). In: CONGRESSO DE INICIAÇÃO CIENTÍFICA, 9., Curitiba, 1989. Curitiba: CNPq/MEC, 1989.

SOWELL, B.F.; WALLACE, M.E.; BRANINE, M.E.; FREDRICKSON, E.L.; BOWMAN, J.G.P. Effects of restricted suckling on forage intake of range calves. Journal of Range Management, v. 49, n. 4, p. 290-293, july/ 1996.

SUNQUIST, F. Capybara ranching in Venezuela. Journal of Applied Rabbit Research., v.9, p. 20-24, 1986.

TENGLER de MaCLURE, M. Estudio sobre los ciliados intestinales del chigüire venezoelano. In: CONGRESO LATINO AMERICANO DE ZOOLOGIA, 4., Caracas, 1968. Resumen de comunicaciones. Caracas, 1968. p.7.

THACKER, E.J. \& BRANDT, C.S. Coprophagy in the rabbit. Journal Nutrition, v.55, p. 375-385, 1955.

THELEN, K.D. Networking to share technical knowledge on wildlife management in Latin America. Unasylva : Wildlife management for rural development, n.161, p. 33-38, 1990.

THOMPSON, K.N.; JACKSON, S.G.; ROONEY, G.R. The effect of above average weigth gains on the incidence of radiographic bone aberrations and epiphisitis in growing horses. Proceedings equus nutrition physiology symposium, 10., p.5, 1987. /Resumo em CAB Abstracts on CD-ROM, $1987 /$.

TORRES, G.C.V. Bases para o estudo da zootecnia. Salvador: Centro Ed. e Didático da UFBA, 1990. p.109-136. 
TRAPIDO, H. Gestation period, young, and maximum weight of the isthmian capybara (Hydrochoerus isthmius Goldmam). Journal of Mammology, v. 30, p.433, 1949.

TREBBAU, P. Some observation on the capybara (Hydrochoerus hydrochaeris). Zoologische Garten, v.50, n.1, p.40-44,1980.

VASEY, D.E. Capybara ranching for Amazonia ? Oryx, v. 15, n. 1, p. 47-49, 1979.

WETTERBERG, G.B.; FERREIRA, M.; BRITO, W.J. dos S.; ARAUJO, V.C. Fauna Amazônica preferida como alimento. Brasília: IBDF - PRODEPEF, 1976. (Série Técnica, 4).

WOHL, M.G.; GOODHART, R.S. Modern nutrition in health and disease. Philadelphia: Lead Febiger, 1964. 1042 p.

ZARA, J.L. Breeding and husbandry of the capybara (Hydrochoerus hydrochaeris). International Zoo Yearbook, New York, n.13, p. 137-139, 1973. 


\section{APÊNDICE 1}

Tabela A-1: Quadro de análise de variância de GDP do Experimento I - parteA .

\begin{tabular}{lccccc}
\hline \multicolumn{1}{c}{ Causas de Variação } & G.L. & Soma dos quadrados & Quadrado médio & F & Prob>F \\
\hline Blocos & 4 & 4959,782 & 1239,945 & 4,48 & 0,019 \\
Nível de EB & 1 & 271,732 & 271,732 & 0,98 & 0,341 \\
Nível de PB & 1 & 1071,062 & 1071,062 & 3,87 & 0,073 \\
EB X PB & 1 & 0,0005 & 0,0005 & 0,00 & 0,998 \\
Resíduo & 12 & 3322,200 & 276,850 & & \\
\hline Total & 19 & 9624,776 & & &
\end{tabular}

Tabela A-2: Quadro de análise de variância do consumo diário de MS do Experimento I - parteA.

\begin{tabular}{lccccc}
\hline \multicolumn{1}{c}{ Causas de Variação } & G.L. & Soma dos quadrados & Quadrado médio & F & Prob>F \\
\hline Blocos & 4 & 47116,600 & 11779,150 & 4,52 & 0,018 \\
Nível de EB & 1 & 3428,533 & 3428,533 & 1,32 & 0,273 \\
Nivel de PB & 1 & 200,091 & 200,091 & 0,08 & 0,786 \\
EB X PB & 1 & 1055,314 & 1055,314 & 0,41 & 0,536 \\
Resíduo & 12 & 31240,602 & 2603,383 & & \\
\hline Total & 19 & 83041,140 & & & \\
\hline
\end{tabular}

Tabela A-3: Quadro de análise de variância da conversão alimentar do Experimento I - parteA (dados transformados, $\lambda=-1$ ).

\begin{tabular}{lccccc}
\hline \multicolumn{1}{c}{ Causas de Variação } & G.L. & Soma dos quadrados & Quadrado médio & F & Prob>F \\
\hline Blocos & 4 & 0,0225 & 0,0056 & 7,34 & 0,003 \\
Nível de EB & 1 & 0,0003 & 0,0003 & 0,44 & 0,518 \\
Nível de PB & 1 & 0,0064 & 0,0064 & 8,35 & 0,014 \\
EB X PB & 1 & 0,0001 & 0,0001 & 0,16 & 0,693 \\
Resíduo & 12 & 0,0092 & 0,0008 & & \\
\hline Total & 19 & 0,0385 & & & \\
\hline
\end{tabular}


Tabela A-4: Quadro de análise de variância de GDP ajustado à covariável consumo no Experimento I parteA

\begin{tabular}{lccccc}
\hline Causas de Variação & G.L. & Soma dos quadrados & $\begin{array}{c}\text { Quadrado } \\
\text { médio }\end{array}$ & F & Prob>F \\
\hline Blocos & 4 & 2950,716 & 737,679 & 7,74 & 0,0032 \\
Nível de EB & 1 & 0,423 & 0,423 & 0,00 & 0,9480 \\
Nível de PB & 1 & 830,523 & 830,523 & 8,72 & 0,0131 \\
EB X PB & 1 & 74,712 & 74,712 & 0,78 & 0,3947 \\
Consumo & 1 & 2274,470 & 2274,470 & 23,88 & 0,0005 \\
Resíduo & 11 & 1047,729 & 95,248 & & \\
\hline Total & 19 & 9624,776 & & & \\
\hline
\end{tabular}

Tabela A-5: Quadro de análise de variância da taxa de mortalidade do Experimento I - parteA.

\begin{tabular}{lccccc}
\hline \multicolumn{1}{c}{ Causas de Variação } & G.L. & Soma dos quadrados & Quadrado médio & F & Prob>F \\
\hline Blocos & 4 & 9536,57 & 1907,31 & 3,43 & 0,02 \\
Nível de EB & 1 & 2268,65 & 2268,65 & 4,08 & 0,06 \\
Nível de PB & 1 & 46,31 & 46,31 & 0,08 & 0,78 \\
EB X PB & 1 & 185,15 & 185,15 & 0,33 & 0,57 \\
Resíduo & 12 & 8333,05 & 555,54 & & \\
\hline Total & 19 & 20639,74 & & &
\end{tabular}

Tabela A-6: Quadro de análise de variância de GDP do Experimento I - parte B .

\begin{tabular}{lccccc}
\hline \multicolumn{1}{c}{ Causas de Variação } & G.L. & Soma dos quadrados & Quadrado médio & F & Prob>F \\
\hline Tratamentos & 3 & 7290,13 & 2430,04 & 4,40 & 0,01 \\
Resíduo & 21 & 11610,80 & 552,89 & & \\
\hline Total & 24 & 18900,93 & & & \\
\hline
\end{tabular}

Tabela A-7: Quadro de análise de variância do consumo diário de MS do Experimento I - parte B.

\begin{tabular}{lccccc}
\hline \multicolumn{1}{c}{ Causas de Variação } & G.L. & Soma dos quadrados & Quadrado médio & F & Prob>F \\
\hline Tratamentos & 3 & 855752,48 & 285250,83 & 91,68 & 0,0001 \\
Resíduo & 22 & 68453,23 & 3111,51 & & \\
\hline Total & 25 & 18900,93 & & & \\
\hline
\end{tabular}


Tabela A-8: Quadro de análise de variância da conversão alimentar do Experimento I - parte B.

\begin{tabular}{lccccc}
\hline \multicolumn{1}{c}{ Causas de Variação } & G.L. & Soma dos quadrados & Quadrado médio & F & Prob>F \\
\hline Tratamentos & 3 & 718,05 & 239,35 & 20,99 & 0,0001 \\
Resíduo & 22 & 239,46 & 11,40 & & \\
\hline Total & 25 & 957,51 & & & \\
\hline
\end{tabular}

Tabela A-9: Quadro de análise de variância de GDP do Experimento I - parte C .

\begin{tabular}{lccccc}
\hline \multicolumn{1}{c}{ Causas de Variação } & G.L. & Soma dos quadrados & Quadrado médio & F & Prob>F \\
\hline Tratamentos & 1 & 49,98 & 49,98 & 0,09 & 0,77 \\
Blocos & 7 & 2472,55 & 353,221 & 0,66 & 0,70 \\
Resíduo & 7 & 3747,43 & 535,35 & & \\
\hline Total & 15 & 6269,97 & & & \\
\hline
\end{tabular}

Tabela A-10: Quadro de análise de variância do consumo diário de MS do Experimento I - parte C.

\begin{tabular}{lccccc}
\hline \multicolumn{1}{c}{ Causas de Variação } & G.L. & Soma dos quadrados & Quadrado médio & F & Prob>F \\
\hline Tratamentos & 1 & 11744,60 & 11744,60 & 4,7 & 0,06 \\
Blocos & 7 & 14069,08 & 2009,86 & 0,8 & 0,60 \\
Resíduo & 7 & 17507,47 & 2501,07 & & \\
\hline Total & 15 & 43321,15 & & & \\
\hline
\end{tabular}

Tabela A-11: Quadro de análise de variância da conversão alimentar do Experimento I - parte C.

\begin{tabular}{lccccc}
\hline \multicolumn{1}{c}{ Causas de Variação } & G.L. & Soma dos quadrados & Quadrado médio & F & Prob>F \\
\hline Tratamentos & 1 & 3,02 & 3,02 & 3,03 & 0,12 \\
Blocos & 7 & 9,57 & 1,37 & 1,37 & 0,34 \\
Resíduo & 7 & 6,97 & 0,996 & & \\
\hline Total & 15 & 19,56 & & & \\
\hline
\end{tabular}




\section{APÊNDICE 2}

Tabela A-12: Quadro de análise de variância do CDMS do Experimento II .

\begin{tabular}{lccccc}
\hline \multicolumn{1}{c}{ Causas de Variação } & G.L. & Soma dos quadrados & Quadrado médio & F & Prob>F \\
\hline Período & 3 & 305,19 & 101,73 & 10,86 & 0,008 \\
Animal & 3 & 46,58 & 15,53 & 1,66 & 0,273 \\
PB & 1 & 77,88 & 77,88 & 8,32 & 0,028 \\
EB & 1 & 0,02 & 0,02 & 0,00 & 0,967 \\
EB X PB & 1 & 4,18 & 4,18 & 0,45 & 0,529 \\
Resíduo & 6 & 56,19 & 9,36 & & \\
\hline Total & 15 & 490,06 & & & \\
\hline
\end{tabular}

Tabela A-13: Quadro de análise de variância do CDMO do Experimento II .

\begin{tabular}{lccccc}
\hline \multicolumn{1}{c}{ Causas de Variação } & G.L. & Soma dos quadrados & Quadrado médio & \multicolumn{1}{c}{ F } & \multicolumn{2}{c}{ Prob>F } \\
\hline Período & 3 & 118,675 & 39,558 & 11,48 & 0,007 \\
Animal & 3 & 18,359 & 6,120 & 1,78 & 0,25 \\
EB & 1 & 0,710 & 0,710 & 0,21 & 0,66 \\
PB & 1 & 35,492 & 35,492 & 10,30 & 0,01 \\
EB X PB & 1 & 1,076 & 1,076 & 0,31 & 0,59 \\
Resíduo & 6 & 20,680 & 3,447 & & \\
\hline Total & 15 & 194,992 & & & \\
\hline
\end{tabular}

Tabela A-14: Quadro de análise de variância do CDPB do Experimento II .

\begin{tabular}{lccccc}
\hline \multicolumn{1}{c}{ Causas de Variação } & G.L. & Soma dos quadrados & Quadrado médio & F & Prob>F \\
\hline Período & 3 & 264,864 & 88,288 & 6,17 & 0,029 \\
Animal & 3 & 50,074 & 16,691 & 1,17 & 0,397 \\
EB & 1 & 17,598 & 17,598 & 1,23 & 0,310 \\
PB & 1 & 53,802 & 53,802 & 3,76 & 0,101 \\
EB X PB & 1 & 5,244 & 5,244 & 0,37 & 0,567 \\
Resíduo & 6 & 85,864 & 14,311 & & \\
\hline Total & 15 & 477,447 & & & \\
\hline
\end{tabular}


Tabela A-15: Quadro de análise de variância do CDEB do Experimento II .

\begin{tabular}{lccccc}
\hline \multicolumn{1}{c}{ Causas de Variação } & G.L. & Soma dos quadrados & Quadrado médio & F & Prob $>$ F \\
\hline Período & 3 & 166,636 & 55,545 & 18,50 & 0,052 \\
Animal & 3 & 18,515 & 6,172 & 2,06 & 0,344 \\
EB & 1 & 1,092 & 1,092 & 0,36 & 0,608 \\
PB & 1 & 25,747 & 25,747 & 8,57 & 0,099 \\
EB X PB & 1 & 1,521 & 1,521 & 0,51 & 0,550 \\
Resíduo & 2 & 6,005 & 3,003 & & \\
\hline Total & 11 & 256,187 & & & \\
\hline
\end{tabular}

Tabela A-16: Quadro de análise de variância do CDEE do Experimento II .

\begin{tabular}{lccccc}
\hline \multicolumn{1}{c}{ Causas de Variação } & G.L. & Soma dos quadrados & Quadrado médio & F & Prob>F \\
\hline Período & 3 & 1833,77 & 611,26 & 9,91 & 0,010 \\
Animal & 3 & 612,48 & 204,16 & 3,31 & 0,098 \\
EB & 1 & 373,65 & 373,65 & 6,06 & 0,049 \\
PB & 1 & 527,16 & 527,16 & 8,55 & 0,026 \\
EB X PB & 1 & 1057,22 & 1057,22 & 17,15 & 0,006 \\
Resíduo & 6 & 369,92 & 61,65 & & \\
\hline Total & 15 & 4774,20 & & & \\
\hline
\end{tabular}

Tabela A-17: Quadro de análise de variância do CDFB do Experimento II (dados transformados, $\lambda=$ $1,5)$.

\begin{tabular}{lccccc}
\hline \multicolumn{1}{c}{ Causas de Variação } & G.L. & Soma dos quadrados & Quadrado médio & F & Prob>F \\
\hline Período & 3 & 538046,85 & 179348,95 & 13,47 & 0,004 \\
Animal & 3 & 35521,05 & 11840,35 & 0,89 & 0,498 \\
EB & 1 & 33756,77 & 33756,77 & 2,54 & 0,162 \\
PB & 1 & 50621,96 & 50621,96 & 3,80 & 0,099 \\
EB X PB & 1 & 11342,41 & 11342,41 & 0,85 & 0,392 \\
Resíduo & 6 & 79881,87 & 13313,64 & & \\
\hline Total & 15 & 749170,92 & & & \\
\hline
\end{tabular}


Tabela A-18: Quadro de análise de variância do CDFDN do Experimento Il .

\begin{tabular}{lccccc}
\hline \multicolumn{1}{c}{ Causas de Variação } & G.L. & Soma dos quadrados & Quadrado médio & F & Prob>F \\
\hline Período & 3 & 1058,67 & 352,89 & 14,38 & 0,004 \\
Animal & 3 & 141,99 & 47,33 & 1,93 & 0,226 \\
EB & 1 & 276,22 & 276,22 & 11,26 & 0,015 \\
PB & 1 & 170,96 & 170,96 & 6,97 & 0,039 \\
EB X PB & 1 & 2,18 & 2,18 & 0,09 & 0,776 \\
Resíduo & 6 & 147,22 & 24,54 & & \\
\hline Total & 15 & 1797,25 & & & \\
\hline
\end{tabular}

Tabela A-20: Quadro de análise de variância do CDFDA do Experimento II (dados transformados, $\lambda=$ $1,5)$.

\begin{tabular}{lccccc}
\hline \multicolumn{1}{c}{ Causas de Variação } & G.L. & Soma dos quadrados & Quadrado médio & F & Prob>F \\
\hline Período & 3 & 486102,57 & 162034,19 & 13,24 & 0,005 \\
Animal & 3 & 53975,65 & 17991,88 & 1,47 & 0,314 \\
EB & 1 & 785,80 & 785,80 & 0,06 & 0,808 \\
PB & 1 & 62988,80 & 62988,80 & 5,15 & 0,064 \\
EB X PB & 1 & 7579,41 & 7579,41 & 0,62 & 0,461 \\
Resíduo & 6 & 73427,09 & 12237,85 & & \\
\hline Total & 15 & 684859,33 & & & \\
\hline
\end{tabular}

Tabela A-21: Quadro de análise de variância do CDENN do Experimento Il .

\begin{tabular}{lccccc}
\hline \multicolumn{1}{c}{ Causas de Variação } & G.L. & Soma dos quadrados & Quadrado médio & F & Prob>F \\
\hline Período & 3 & 56,03 & 18,68 & 13,39 & 0,005 \\
Animal & 3 & 6,51 & 2,17 & 1,56 & 0,294 \\
PB & 1 & 12,18 & 12,18 & $\mathbf{8 , 7 3}$ & 0,020 \\
EB & 1 & 1,25 & 1,25 & 0,90 & 0,370 \\
EB X PB & 1 & 0,10 & 0,10 & 0,07 & 0,790 \\
Resíduo & 6 & 8,37 & 1,39 & & \\
\hline Total & 15 & $\mathbf{8 4 , 4 4}$ & & & \\
\hline
\end{tabular}


Tabela A-22 : Coeficientes de Digestibilidade Aparente da Matéria Seca .

\begin{tabular}{lcccc}
\hline & T1 & T2 & T3 & T4 \\
\hline I & 89,59 & 85,39 & 93,82 & 89,68 \\
II & 96,36 & 92,85 & 97,61 & 95,93 \\
III & 87,59 & 86,75 & 84,75 & 74,75 \\
IV & 92,20 & 87,89 & 94,61 & 88,69 \\
\hline
\end{tabular}

Tabela A-23 : Coeficientes de Digestibilidade Aparente da Matéria Orgânica .

\begin{tabular}{lcccc}
\hline & T1 & T2 & T3 & T4 \\
\hline I & 93,42 & 89,96 & 95,84 & 92,66 \\
II & 97,52 & 94,98 & 98,37 & 97,18 \\
III & 91,87 & 91,17 & 90,19 & 84,16 \\
IV & 94,30 & 91,16 & 96,47 & 92,88 \\
\hline
\end{tabular}

Tabela A-24 : Coeficientes de Digestibilidade Aparente da Proteína Bruta .

\begin{tabular}{lcccc}
\hline & T1 & T2 & T3 & T4 \\
\hline I & 91,41 & 85,06 & 93,02 & 87,44 \\
II & 95,60 & 93,10 & 97,12 & 94,65 \\
III & 88,09 & 90,41 & 81,13 & 75,18 \\
IV & 92,71 & 89,15 & 92,73 & 87,47 \\
\hline
\end{tabular}

Tabela A-25 : Coeficientes de Digestibilidade Aparente do Extrato Etéreo.

\begin{tabular}{lcccc}
\hline & T1 & T2 & T3 & T4 \\
\hline I & 47,18 & 51,14 & 72,43 & 50,19 \\
II & 77,76 & 67,08 & 89,97 & 72,63 \\
III & 31,19 & 66,39 & 65,13 & 39,74 \\
IV & 49,23 & 39,86 & 81,51 & 35,54 \\
\hline
\end{tabular}


Tabela A-26 : Coeficientes de Digestibilidade Verdadeira da Fibra Bruta.

\begin{tabular}{lcccc}
\hline & T1 & T2 & T3 & T4 \\
\hline I & 68,73 & 62,68 & 74,74 & 59,17 \\
II & 90,02 & 84,95 & 93,30 & 88,01 \\
III & 61,53 & 66,37 & 42,33 & \\
IV & 84,38 & 73,07 & 79,17 & 66,05 \\
\hline
\end{tabular}

Tabela A-27 : Coeficientes de Digestibilidade Verdadeira da Fibra Detergente Neutro.

\begin{tabular}{lcccc}
\hline & T1 & T2 & T3 & T4 \\
\hline I & 77,69 & 63,27 & 91,37 & 85,17 \\
II & 92,28 & 85,53 & 97,33 & 95,43 \\
III & 67,92 & 72,79 & 78,69 & 63,64 \\
IV & 86,18 & 79,28 & 92,84 & 86,91 \\
\hline
\end{tabular}

Tabela A-28 : Coeficientes de Digestibilidade Verdadeira da Fibra Detergente Ácido.

\begin{tabular}{lcccc}
\hline & T1 & T2 & T3 & T4 \\
\hline I & 72,09 & 61,85 & 82,12 & 71,93 \\
II & 90,63 & 83,82 & 95,25 & 90,84 \\
III & 63,86 & 64,98 & 53,27 & - \\
IV & 82,50 & 73,41 & 85,45 & 73,22 \\
\hline
\end{tabular}

Tabela A-29 : Coeficientes de Digestibilidade Aparente do Extrativo Não-nitrogenado.

\begin{tabular}{lllll}
\hline & T1 & T2 & T3 & T4 \\
\hline I & 96,00 & 94,43 & 97,79 & 96,21 \\
II & 98,72 & 97,13 & 99,03 & 98,74 \\
III & 94,81 & 93,76 & 94,19 & 89,99 \\
IV & 96,79 & 94,65 & 98,18 & 96,64 \\
\hline
\end{tabular}




\section{APÊNDICE 3}

Tabela A-30: Consumo médio diário de nutrientes pelas capivaras no ensaio de digestibilidade (Experimento II)

\begin{tabular}{lcccc}
\hline NUTRIENTES & T1 & T2 & T3 & T4 \\
\hline MS (g/dia) & 181,95 & 159,29 & 154,31 & 175,50 \\
MO (g/dia) & 181,06 & 155,88 & 154,05 & 174,54 \\
MM (g/dia) & 0,89 & 3,40 & 0,26 & 0,96 \\
EB (kcal/dia) & 708,10 & 591,90 & 606,14 & 732,60 \\
PB (g/dia) & 31,79 & 33,41 & 21,70 & 29,87 \\
FB (g/dia) & 6,69 & 6,67 & 4,26 & 5,02 \\
EE (g/dia) & 2,83 & 3,95 & 3,90 & 3,72 \\
FDN (g/dia) & 21,03 & 20,19 & 30,39 & 34,22 \\
FDA (g/dia) & 10,83 & 10,14 & 8,71 & 8,80 \\
ENN (g/dia) & 139,74 & 111,84 & 124,45 & 135,93 \\
\hline
\end{tabular}

